\title{
SKEWED CREDIT AND GROWTH DYNAMICS AFTER THE GLOBAL FINANCIAL CRISIS
}

Gemma Estrada, Aitor Erce, Donghyun Park, and Juan Rojas

NO. 562

October 2018
ADB ECONOMICS WORKING PAPER SERIES 


\section{Skewed Credit and Growth Dynamics after the Global Financial Crisis}

Gemma Estrada, Aitor Erce, Donghyun Park, and Juan Rojas

No.562 | October 2018
Gemma Estrada (gestrada@adb.org) is Senior Economics Officer and Donghyun Park (dpark@adb.org) is Principal Economist in the Economic Research and Regional Cooperation Department of the Asian Development Bank. Aitor Erce (a.erce@esm.europa.eu) is Principal Economist and Juan Rojas (j.rojas@esm.europa.eu) is Head of Economic and Market Analysis in the European Stability Mechanism.

The views in this paper are those of the authors and do not reflect the views of the European Stability Mechanism, their board of directors, or management. We gratefully acknowledge the valuable editorial contributions of Cynthia Castillejos-Petalcorin and Kevin Donahue. 
(c) 2018 Asian Development Bank

6 ADB Avenue, Mandaluyong City, 1550 Metro Manila, Philippines

Tel +632632 4444; Fax +6326362444

www.adb.org

Some rights reserved. Published in 2018.

ISSN 2313-6537 (print), 2313-6545 (electronic)

Publication Stock No. WPS189595-2

DOI: http://dx.doi.org/10.22617/WPS189595-2

The views expressed in this publication are those of the authors and do not necessarily reflect the views and policies of the Asian Development Bank (ADB) or its Board of Governors or the governments they represent.

ADB does not guarantee the accuracy of the data included in this publication and accepts no responsibility for any consequence of their use. The mention of specific companies or products of manufacturers does not imply that they are endorsed or recommended by ADB in preference to others of a similar nature that are not mentioned.

By making any designation of or reference to a particular territory or geographic area, or by using the term "country" in this document, $A D B$ does not intend to make any judgments as to the legal or other status of any territory or area.

This work is available under the Creative Commons Attribution 3.0 IGO license (CC BY 3.0 IGO)

https://creativecommons.org/licenses/by/3.o/igo/. By using the content of this publication, you agree to be bound by the terms of this license. For attribution, translations, adaptations, and permissions, please read the provisions and terms of use at https://www.adb.org/terms-use\#openaccess.

This CC license does not apply to non-ADB copyright materials in this publication. If the material is attributed to another source, please contact the copyright owner or publisher of that source for permission to reproduce it. $\mathrm{ADB}$ cannot be held liable for any claims that arise as a result of your use of the material.

Please contact pubsmarketing@adb.org if you have questions or comments with respect to content, or if you wish to obtain copyright permission for your intended use that does not fall within these terms, or for permission to use the ADB logo.

Notes:

In this publication, “\$” refers to United States dollars.

Corrigenda to ADB publications may be found at http://www.adb.org/publications/corrigenda. 


\section{CONTENTS}

TABLES

ABSTRACT

$\begin{array}{ll}\text { I. INTRODUCTION } & 1\end{array}$

II. DATA 3

A. Country Sample from Ranciere, Tornell, and Westermann (2008) 4

B. Extended Sample $\quad 5$

C. $\quad$ Trends by Decades $\quad 6$

D. Credit Skewness and Crises $\quad 7$

E. Credit Skewness and Economic Growth Patterns $\quad 7$

III. METHODOLOGY $\quad 9$

A. Nonlinearities: Positive versus Negative Skewness 10

B. Negative Skewness and Credit Busts 10

C. Nonlinearities and Credit Deleveraging 11

IV. EMPIRICAL RESULTS 11

A. Ranciere, Tornell, and Westermann (2008) Sample 11

B. Extended Sample 12

C. Extensions of the Ranciere, Tornell, and Westermann (2008) Sample 22

D. Credit Skewness and Higher Moments of Output Growth 33

V. CONCLUSIONS

$\begin{array}{ll}\text { APPENDIX } & 37\end{array}$

$\begin{array}{ll}\text { REFERENCES } & 45\end{array}$ 


\section{TABLES AND FIGURES}

\section{TABLES}

1 Shares of Observations of Positive and Negative Skewness, 1971-2016

2 Average Gross Domestic Product per Capita Growth-Periods of Negative Credit Skewness versus Periods of Positive Credit Skewness, 1971-2016

3 Skewness and Growth (Dependent Variable-Real Gross Domestic Product per Capita Growth) 14

4a Skewness and Growth of Extended Sample, 1971-2016 (Panel Generalized Least Squares) 15

4b Skewness and Growth of Extended Sample, 1971-2016 (Fixed Effects) 18

4c Skewness and Growth of Extended Sample, 1971-2016 (Ordinary Least Squares) 21

5a Skewness and Growth-Ranciere, Tornell, and Westermann (2008) Sample, 1971-2000 (Panel Generalized Least Squares)

5b Skewness and Growth of Ranciere, Tornell, and Westermann (2008) Sample, 1971-2000 (Fixed Effects)

6a Skewness and Growth of Ranciere, Tornell, and Westermann (2008) Sample, 1971-2016 (Panel Generalized Least Squares)

6b Skewness and Growth of Ranciere, Tornell, and Westermann (2008) Sample, 1971-2016 (Fixed Effects)

$7 \quad$ Skewness and Standard Deviation of Gross Domestic Product Growth as Dependent Variables

8 Summary of Results for Skewness and Standard Deviation of Gross Domestic Product per Capita Growth and Credit Growth 35

A1 Data Description and Sources $\quad 37$

A2a Descriptive Statistics, Ranciere, Tornell, and Westermann (2008) Sample (44 Economies) 38

A2b Descriptive Statistics, Extended Sample (82 Economies) 39

A3 Descriptive Statistics on Skewness and Standard Deviation of Gross Domestic Product per Capita Growth $\quad 40$

A4 Credit Skewness and Economic Growth-Extended Sample 41

\section{FIGURES}

$1 \quad$ Average Skewness 5

2 Shares of Observations with Negative and Positive Skewness 6

3 Mean Skewness of Credit Growth and Crises, 1971-2010 8

4 Mean Skewness of Credit Growth in Periods with and without Banking Crises, 1971-2010 8 


\begin{abstract}
A large empirical literature finds that financial development is beneficial for economic growth, although some recent evidence suggests otherwise. We contribute to the finance-growth literature by examining the role of credit growth skewness and long-run growth. Earlier literature found that credit growth skewness is negatively associated with economic growth. We revisit this relationship using a large and recent panel dataset that encompasses Organisation for Economic Co-operation and Development economies and the impact of the global financial crisis. While our results reconfirm an association between credit skewness and growth, the relationship is more nuanced than previously thought. We find that the beneficial effects from lower skewness-systemic financial risks-were evident only prior to 2000. Our findings help explain why boom-bust dynamics were positively associated with economic growth in emerging markets in the past and why the growth of advanced economies has been sluggish since the global financial crisis.
\end{abstract}

Keywords: credit dynamics, economic growth, skewness

JEL codes: F34, F36, F43, O41 


\section{INTRODUCTION}

A large empirical literature shows that financial sector development is positively associated with economic growth. ${ }^{1}$ Nevertheless, the 2008-2009 global financial crisis has cast some doubt about whether finance is necessarily beneficial for growth. Empirically, a growing number of studies find that the beneficial effects are nonmonotonic, with some financial configurations delivering worse output outcomes. ${ }^{2}$ According to this literature, financial innovation exposes economies to financial crises, which can adversely affect economic crises. The global financial crisis, which was preceded by a wave of financial innovation related to the United States housing market, is a case in point.

In a widely cited contribution, Ranciere, Tornell, and Westermann (2008) study the role of credit skewness in economic growth to better understand the finance-growth nexus. ${ }^{3}$ Credit skewness is defined here as the distribution of credit growth of a country within a period or decade. Using a panel of 58 economies during the period 1960-2000, Ranciere, Tornell, and Westermann (2008) show that credit dynamics, as measured by the growth rate of real credit to the private sector, feature significant cross-economy differences in skewness. According to their empirical results, economies characterized by negative skewness in private sector credit growth, which they assume to be a proxy for systemic financial risk, experience faster growth. ${ }^{4}$ The key takeaway is that systemic risk-taking mitigates financial bottlenecks and promotes growth in economies with weak institutions through its effect on investment, even though it also leads to occasional crises.

The global financial crisis severely disrupted the global financial system and dented global growth momentum. The growth impact was more pronounced and longer-lasting in advanced economies, which were the epicenter of the crisis, putting into question the general validity of the above finding. Against this background, we assess whether the negative relation between credit skewness and output growth remains robust once the global financial crisis is included in the analysis. One possible explanation is that the finance-growth link differs in advanced versus developing economies, an issue that has not been explored in Ranciere, Tornell, and Westermann (2008). We examine whether this is the case using a new dataset, which encompasses both advanced and developing economies as well as the postglobal financial crisis period. To further our understanding of the link between credit skewness and growth, we also test the extent to which the size and sign of credit growth skewness affect economic growth.

Most empirical studies showing positive spillovers from finance to growth analyze the relation with a linear panel data framework. These studies explore the effect of the level of finance on the level of growth, and generally find a significant and positive relationship between the two (King and Levine 1993, Levine and Zervos 1998, Demirgüç-Kunt and Levine 1996, Beck and Levine 2004).

\footnotetext{
Levine (2004) reviews the literature and argues that, despite significant measurement and econometric difficulties, existing evidence signals a beneficial causal effect of finance on growth. Estrada, Park, and Ramayandi (2010), focusing on Asian economies, reach the same conclusion.

2 This is the so-called "too much finance" literature (see Arcand, Berkes, and Panizza 2012).

3 Related to this, Adrian, Boyarchenko, and Giannone (2017) and Popov (2014) argue that where output is more volatile, it is also more skewed.

4 These authors argue that skewness proxies for the presence of systemic risk and that risk works as an incentive to overcome institutional problems. The logic behind this result is that when economies need to circumvent informational asymmetries, such as those due to a lack of institutional development, they can do so by generating systemic risk (boombust cycles).
} 
In recent years, some authors have shown the existence of nonlinearities in the finance-growth nexus. Arcand, Berkes, and Panizza (2012) show that, beyond some level, higher private credit do not lead to higher growth and can lead instead to lower long-run growth due to hysteresis. Other authors point out that financial boom-bust cycles affect growth in a plethora of ways, not all of them well understood. Some papers highlight channels at work during the leveraging phase, while others highlight channels at play during the deleveraging phase. Easterly, Islam, and Stiglitz (2000) empirically show that there is a convex and nonmonotonic relationship between financial depth and output growth volatility. Financial deepening smooths consumption and reduces volatility only up to a limit beyond which further financial development implies excessive leverage and thus more risks and instability. Bezemer (2012) argues that financial development has two sides: gross domestic product (GDP)enhancing and asset-prices enhancing. ${ }^{5}$ Aghion et al. (2005) show that, in the presence of borrowing constraints, more financially developed countries suffer less volatility and reach higher output growth. Along these lines, Ranciere, Tornell, and Westermann (2006) show that the negative effect of crisis on growth is not enough to overturn the beneficial effect of more credit. Similarly, Philippon (2012) argues that capital misallocation may be more damaging in economies with more finance. According to this literature, financial development can be volatile and result in financial crisis, which affects both the level and volatility of output growth. This perverse effect of the second moment of finance (volatility) can reduce its beneficial effects on growth.

Closest to us, Ranciere, Tornell, and Westermann (2008) draw a parallel between boom-bust cycles and the skewness of the distribution of credit growth, and show that negative credit skewness is associated with stronger economic growth. Relatedly, Ramey and Ramey (1995) studied the link between the average and the volatility of economic growth, giving rise to a large body of literature on the relation between the average and the volatility of output growth distribution. The stylized fact that emerges from this literature is that countries with more volatile growth experience lower average growth. Digging further into this relation among distributional moments, Bekaert and Popov (2012) find that within the cross-section there is a positive relation between the volatility and skewness of growth. ${ }^{6}$ Using micro data, Salgado, Guvenen, and Bloom (2015) document a positive relationship between average growth and average skewness. ${ }^{7}$

In this paper, we find some support for the relation between credit skewness and growth found by Ranciere, Tornell, and Westermann (2008). However, the relation seems to break down for advanced economies, especially in the more recent period. Specifically, we observe for these economies that negative skewness appears to have had a positive effect on growth prior to-but not after-the global financial crisis. We also find some evidence that skewness has a nonlinear relation with economic growth, and that both positive and negative skewness can have a positive effect on economic growth.

Motivated by a literature that argues credit recessions play a cleansing role in financial systems (Bezemer 2012), we also examine whether deleveraging helps determine the relationship between credit dynamics and economic growth, beyond the sign of skewness. We show that economies suffering credit stagnation experience lower output growth than those characterized by credit recessions, and that credit stagnation is the more likely of the two when skewness is positive.

\footnotetext{
Bezemer, Grydaki, and Lu (2014) show that financial flows were an important determinant of the Great Moderation. They argue that this is due to the existence of growth miracles and financial meltdowns in advanced economies.

According to their findings, it is during recessions, when cross-firm growth is lower, that the distribution of growth becomes more negatively skewed. See also Adrian, Boyarchenko, and Giannone (2017) and Popov (2014).
} 
The rest of this paper is organized as follows. In section II, we describe the data used in our empirical analysis. Section III explains our econometric strategy, while section IV reports and discusses our empirical results. Section $\vee$ concludes our paper.

\section{DATA}

We first build a dataset analogous to that in Ranciere, Tornell, and Westermann (2008), which we will refer to as the "RTW sample." To check for the robustness of the relationship between skewness and growth, we build a larger sample containing 82 economies. Our extended sample contains all economies with available data in the World Bank's World Development Indicators (WDI) and the International Monetary Fund's International Financial Statistics (IFS) for the period 1971-2016.

Pooling all cross-economy data by decade, we have a total of 120 observations (economy and decade pairs) in the RTW sample for 1971-2000 and 328 observations in the extended sample. Note that for the RTW sample during 1971-2016, there are 197 observations. Data sources, descriptive statistics, and data summaries by decade are shown in Tables A1, A2, A3, and A4 in the Appendix. As in Ranciere, Tornell, and Westermann (2008), our sample does not include economies that suffered severe war or large terms-of-trade deterioration. ${ }^{8}$ There is a need to control for these two events since they are expected to lead to a large fall in credit. Once these factors are controlled for, skewness is more likely to capture financial crises. Later, we examine whether skewness is closely linked with wellknown measures of financial crisis.

We calculate skewness of growth in private credit by the banking sector using data from the IFS. Since our sample period is 1971-2016, skewness is calculated for each country and each of the following 10-year periods, except for the last period which covers only 6 years: (i) 1971-1980, (ii) 19811990, (iii) 1991-2000, (iv) 2001-2010, and (v) 2011-2016.9

To compute growth in real bank credit, we deflate nominal credit by Consumer Price Index data from the IFS. Average per capita GDP growth is estimated using data from the WDI. We include standard control variables in growth regressions. These are initial GDP per capita, which accounts for growth convergence, and initial schooling level, which captures human capital and is proxied by gross secondary school enrollment. Both are taken from the WDI.

8 The countries with severe war cases are Algeria, the Republic of the Congo, the Democratic Republic of the Congo, El Salvador, Guatemala, Iran, Nicaragua, Peru, the Philippines, Sierra Leone, South Africa, and Uganda. The source for war episodes is the Heidelberg Institute of International Conflict Research, based on the average number of violent deaths. An economy is classified as having experienced a severe war episode if the ratio of average violent deaths to average population is more than 5 per 100,000 for 2 consecutive years. The large terms-of-trade deterioration cases are Algeria, the Republic of the Congo, the Democratic Republic of the Congo, Cote d'Ivoire, Ecuador, Egypt, Ghana, Haiti, Iran, Pakistan, Sri Lanka, Nicaragua, Nigeria, Sierra Leone, Syria, Togo, Trinidad and Tobago, Uganda, Venezuela, and Zambia. An economy is classified as having experienced a large terms-of-trade deterioration if its terms-of-trade index worsened by more than $30 \%$ in a single year or if it experienced an average annual deterioration of more than $25 \%$ (or $20 \%$ ) in 2 (or 3) consecutive years. Other crises or events such as extreme natural disasters may lead to declines in credit, but we don't cover them here due to data limitations

9 Skewness is estimated for each country in each period/decade as follows:

$$
S K=\frac{\sum_{t=1}^{T}\left(Y_{t}-\bar{Y}\right)^{3} / T}{s^{3}}
$$

where $\bar{Y}$ is the mean credit growth for the entire decade, $s$ is the standard deviation of credit growth, $i$ is each year within a decade with credit growth data, and $T$ is the total number of years within a period/decade on which credit skewness is calculated. A period with negative skewness is characterized by abrupt declines in credit growth and thus have a left tail that is long relative to the right tail in the distribution. 
The variables are estimated for each 10-year nonoverlapping period, except the last period (2011-2016). As in the RTW sample, initially we use data until 2000 and compare the results for 19712000 versus 2001-2016. Then we examine the data for the entire period 1971-2016. Our initial sample covers 44 economies out of the 58 included in the RTW sample, and then we expand our sample to 82 countries. $^{10}$

\section{A. Country Sample from Ranciere, Tornell, and Westermann (2008)}

Columns (1) and (2) of Table 1 show that the RTW sample contains more decades of positive credit skewness than of negative credit skewness. However, this was more evident during 1971-2000 than in the entire period 1971-2016.

Table 1: Shares of Observations of Positive and Negative Skewness, 1971-2016

\begin{tabular}{lcc|ccccc|c}
\hline & $\begin{array}{c}\text { Negative } \\
\text { Skewness } \\
(1)\end{array}$ & $\begin{array}{c}\text { Positive } \\
\text { Skewness } \\
(2)\end{array}$ & $\begin{array}{c}\text { Highly } \\
\text { Positive } \\
(3)\end{array}$ & $\begin{array}{c}\text { Moderately } \\
\text { Positive } \\
(4)\end{array}$ & $\begin{array}{c}\text { Approximately } \\
\text { Symmetric } \\
(5)\end{array}$ & $\begin{array}{c}\text { Moderately } \\
\text { Negative } \\
(6)\end{array}$ & $\begin{array}{c}\text { Highly } \\
\text { Negative } \\
(7)\end{array}$ & Total \\
\hline $\begin{array}{l}\text { RTW sample } \\
\begin{array}{l}\text { (1971-2000) } \\
\text { Developing } \\
\text { economies }\end{array}\end{array}$ & 40.3 & 59.7 & 12.9 & 21.0 & 46.8 & 8.1 & 11.3 & 100.0 \\
$\begin{array}{l}\text { OECD } \\
\text { Total }\end{array}$ & 43.1 & 56.9 & 17.2 & 15.5 & 55.2 & 8.6 & 3.4 & 100.0 \\
\hline $\begin{array}{l}\text { RTW sample } \\
\text { (1971-2016) }\end{array}$ & 41.7 & 58.3 & 15.0 & 18.3 & 50.8 & 8.3 & 7.5 & 100.0 \\
$\begin{array}{l}\text { Developing } \\
\text { economies }\end{array}$ & 43.4 & 56.6 & 11.1 & 18.2 & 46.5 & 11.1 & 13.1 & 100.0 \\
$\begin{array}{l}\text { OECD } \\
\begin{array}{l}\text { Total } \\
\hline \text { Extended sample }\end{array}\end{array}$ & 51.0 & 49.0 & 13.3 & 12.2 & 61.2 & 8.2 & 5.1 & 100.0 \\
$\begin{array}{l}\text { (1971-2016) } \\
\text { Developing } \\
\text { economies }\end{array}$ & 44.2 & 52.8 & 12.2 & 15.2 & 53.8 & 9.6 & 9.1 & 100.0 \\
$\begin{array}{l}\text { OECD } \\
\begin{array}{l}\text { Total } \\
\hline\end{array}\end{array}$ & 50.0 & 50.0 & 13.2 & 12.3 & 58.8 & 9.6 & 6.1 & 100.0 \\
\hline
\end{tabular}

OECD = Organisation for Economic Co-operation and Development; RTW = Ranciere, Tornell, and Westermann (2008).

Note: The degrees of skewness in columns (3)-(7) correspond to the following: (i) highly positive (negative): skewness greater than 1.0 (less than 1.0); (ii) moderately positive (negative): between 0.5 and 1.0 (between -1.0 and -0.5 ); and (iii) approximately symmetric: between -0.5 and 0.5 .

Source: Authors' estimates.

Table 1 also shows that in both high-income Organisation for Economic Co-operation and Development (OECD) economies and developing economies, there are more decades of positive skewness than negative skewness in the 1971-2000 RTW sample. We find that the gap between the shares of positive skewness and negative skewness is higher among developing economies. There is a greater tendency for developing economies than advanced economies to exhibit positive rather than negative skewness. For the full sample period (1971-2016), the pattern in advanced economies is

10 The estimation in Ranciere, Tornell, and Westermann (2008) covers 1961-2000, but we no longer cover $1961-1970$ and 14 out of the original 58 economies due to a lack of gross secondary enrollment data in the WDI. We also apply the condition that data on a given decade are only included in the sample if they have at least 7 years of credit growth. 
different from the RTW sample during 1971-2000. Specifically, the proportion of advanced economies with negative skewness was slightly higher than the proportion with positive skewness.

Following Bulmer (1979), observations are grouped by degree of skewness, whether highly or moderately positive (negative), or approximately symmetric, in columns (3) to (7) of Table 1. We find that $47 \%$ of developing economies in the RTW sample are approximately symmetric, both for the period 1971-2000 or 1971-2016 (Table 2). We also find that advanced economies have a greater proportion of events with approximately symmetric distributions compared with developing economies. After breaking down the distributions into degrees of skewness, we find that there are more events of moderately or highly positive skewness than moderately or highly negative credit skewness in both advanced and developing economies.

As shown in Figure 1 and Table A2a for the RTW sample, over the period 1971-2016, advanced economies on average had higher credit skewness than developing economies. Advanced economies exhibited lower average real credit growth than developing economies and had more stable credit growth patterns as shown by the standard deviation of credit. In the earlier period 1971-2000, advanced economies had slightly higher average credit growth and lower credit growth volatility than developing economies. They also had higher skewness, indicating that they appeared to have had less systemic risk relative to developing economies. However, this pattern seems to have reversed during 2001-2016, with advanced economies having lower skewness than developing economies. Mean average credit growth is lower for advanced economies during 2001-2016 compared with 1971-2000. However, volatility, as measured by the coefficient of variation, is higher (1.74 versus 1.38). In contrast, average credit growth increased in developing economies, corresponding to less volatility in credit growth as well as higher output growth.

\section{B. Extended Sample}

The patterns of the extended sample over the period 1971-2016 mirror those of the RTW sample. In particular, there are more periods of positive credit skewness than negative credit skewness for the full sample of economies as well as the developing economy subsample, but not in the OECD subsample (Table 1). In terms of average credit skewness, Figure 1 shows that advanced economies and developing economies have almost similar mean skewness over the period 1971-2016. However, credit skewness was higher in advanced economies than in developing economies during 1971-2000, but the pattern was reversed during 2001-2016.

Figure 1: Average Skewness

(a) RTW

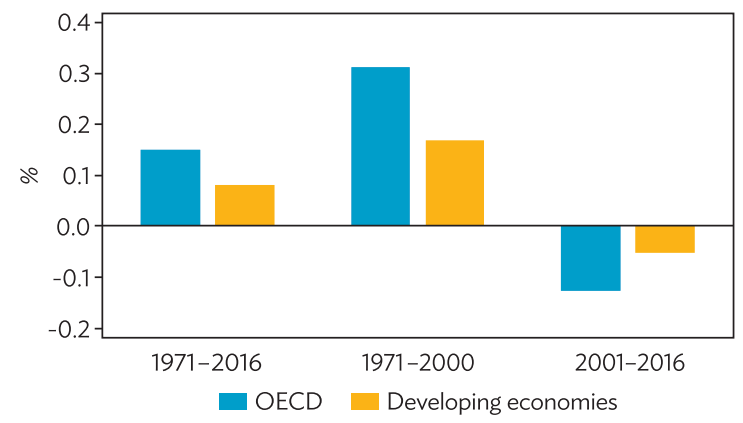

(b) Extended sample

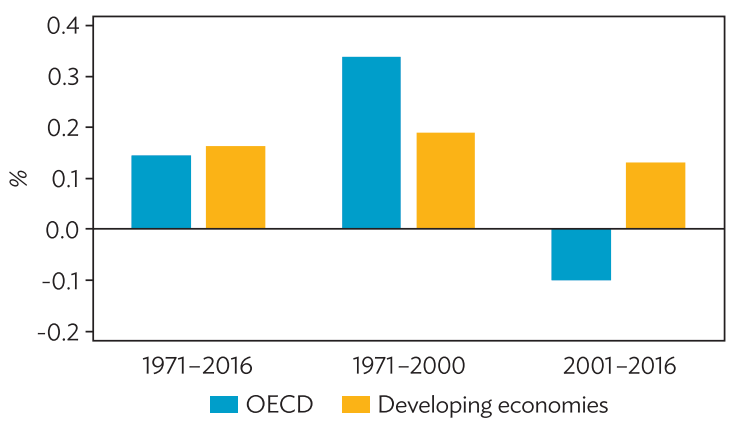

OECD = Organisation for Economic Co-operation and Development; RTW = Ranciere, Tornell, and Westermann (2008). Source: Authors' estimates. 
On average, real credit growth is about one-third higher in developing economies than in advanced economies. However, developing economies have dealt with more volatile credit growth patterns. Developing economies have grown faster but experienced less stable economic growth than advanced economies (Tables A2b, A3). Economic growth skewness is on average negative for both advanced and developing economies (Table A3).

\section{Trends by Decades}

Figure 2 shows the patterns of skewness by decade. In both the RTW and extended samples, the tendency for positive skewness outweighs the tendency for negative skewness across decades. However, this was not evident during 2001-2010, which is the period that includes the global financial crisis. During this decade, the shares of highly negative skewness was double that of the decades from 1971 to 2000 in both samples. This is consistent with the story of abrupt credit disruptions during the global financial crisis. In sum, what largely accounts for the narrow gap between the shares of negative and positive skewness for the entire period 1971-2016 is the global financial crisis decade of 2001-2010 when there was a relatively sharp jump in the shares of observations with moderately and highly negative skewness.

Figure 2: Shares of Observations with Negative and Positive Skewness

(a) RTW sample

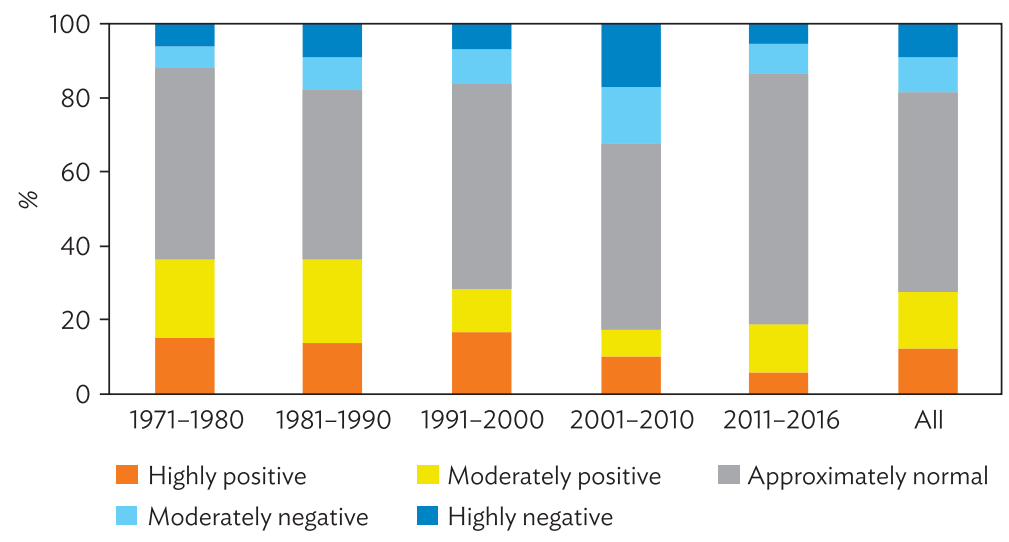

(b) Extended sample

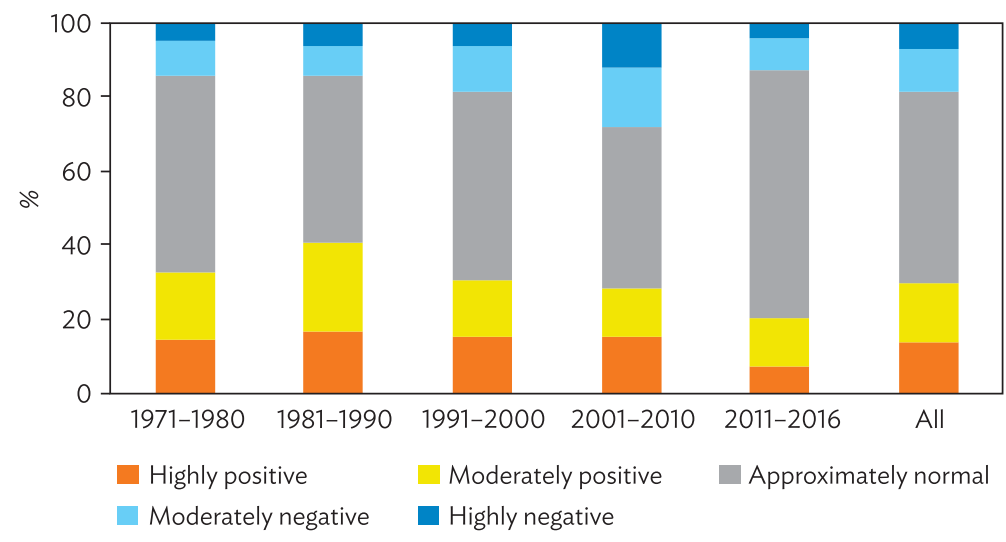

RTW = Ranciere, Tornell, and Westermann (2008).

Source: Authors' estimates. 


\section{Credit Skewness and Crises}

We now examine how closely credit skewness is related to widely known crisis indices, using data from Reinhart and Rogoff (2011) and Laeven and Valencia (2012). We compare mean skewness between decades with crises and decades without crises.

For the Reinhart and Rogoff (2011) banking crisis and currency crisis indices, we cover a subsample of 36 economies, comprising 125 economy-decade pairs with data on skewness over the period 1971-2010. This is shown in Figure 3a. Data in this figure indicate that periods with either type of crises have lower average skewness in credit growth. The gap is most pronounced in periods with banking crises. Based on the t-tests, there are significant differences between mean skewness in decades with banking crises and mean skewness in decades without banking crises. However, there are no significant differences between mean skewness in periods with and without currency crises. Note that mean skewness is positive for periods with banking crises, periods with currency crises, and periods with both types of crises, suggesting that crises are not always captured by negative skewness.

The Laeven and Valencia (2012) crises data allow us to cover more economies and observations, namely 71 economies and 228 economy-decade pairs (Figure 3b). The t-test results show that there are significant differences between the mean skewness of observations with and without banking crises. Statistical differences were likewise detected between periods with either banking or currency crises and periods without crises. Unlike our findings for the Reinhart and Rogoff (2011) indices, according to the Laeven and Valencia (2012) indices, crises periods are clearly characterized by negative skewness.

We next compare skewness in normal versus crisis decades for the OECD and developing economy subsamples with respect to banking crises. On average, credit skewness is significantly lower during periods of banking crises compared with normal events among OECD economies (Figure 4). In the case of developing economies, credit skewness was not statistically different between periods with and without banking crises. This holds true for both the Reinhart and Rogoff (2011) and Laeven and Valencia (2012) banking crisis indices.

\section{E. Credit Skewness and Economic Growth Patterns}

Here we examine associations between skewness of credit growth and average economic growth. Data indicate that periods of negative skewness are associated with higher growth compared with periods of positive skewness. Table 2 shows that during 1971-2000 in the RTW sample, average per capita GDP growth during the periods of negative credit skewness was higher compared with periods of positive skewness. However, during the period 1971-2016, growth appeared only somewhat higher for advanced economies in periods of negative skewness compared with positive skewness. For developing economies, there appears to be not much difference. Results from a formal t-test indicate that there are statistical differences in growth between positive and negative skewness during 1971-2000 (in the full sample and the OECD subsample) but not during 1971-2016 (either in the RTW or extended sample).

For periods with moderately or highly negative skewness versus periods with moderately or highly positive skewness, the patterns now differ from just looking at negative skewness versus positive skewness. For example, in the RTW sample during 1971-2016, GDP per capita growth was higher in periods with negative skewness compared with periods with positive skewness in the OECD subsample. However, for the same OECD subsample, GDP per capita growth was lower in periods with 
moderately or highly negative credit skewness compared with periods with moderately or highly positive skewness. Thus, the relationship does not appear robust. In the next section, we discuss our approach to a systematic analysis of the link between negative skewness and economic growth.

Figure 3: Mean Skewness of Credit Growth and Crises, 1971-2010

(a) Reinhart and Rogoff (2011) Indices

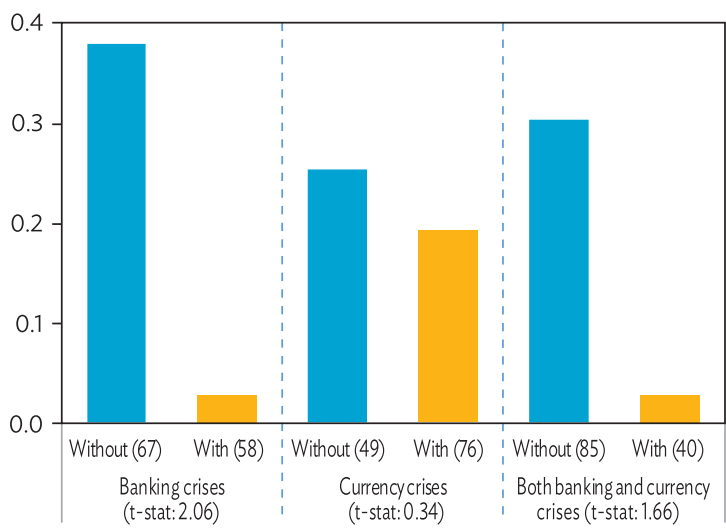

(b) Laeven and Valencia (2012) Indices

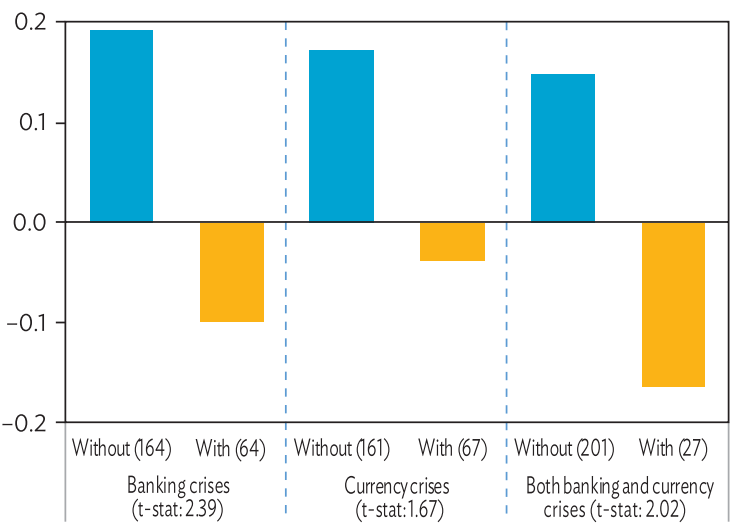

Notes: Data from Reinhart and Rogoff (2011) cover 125 economy-decade pairs and include 58 banking crises, 76 currency crises, and 40 banking and currency crises. The Laeven and Valencia (2012) data cover 228 economy-decade pairs and include 64 banking crises, 67 currency crises, and 27 banking and currency crises. The number of observations is enclosed in parentheses after the labels.

Source: Authors' estimates.

Figure 4: Mean Skewness of Credit Growth in Periods with and without Banking Crises, 1971-2010

(a) Reinhart and Rogoff (2011) Indices

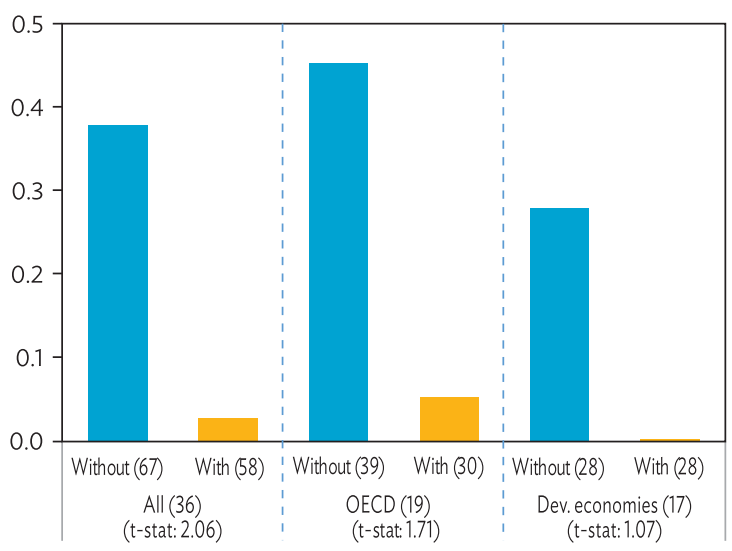

(b) Laeven and Valencia (2012) Indices

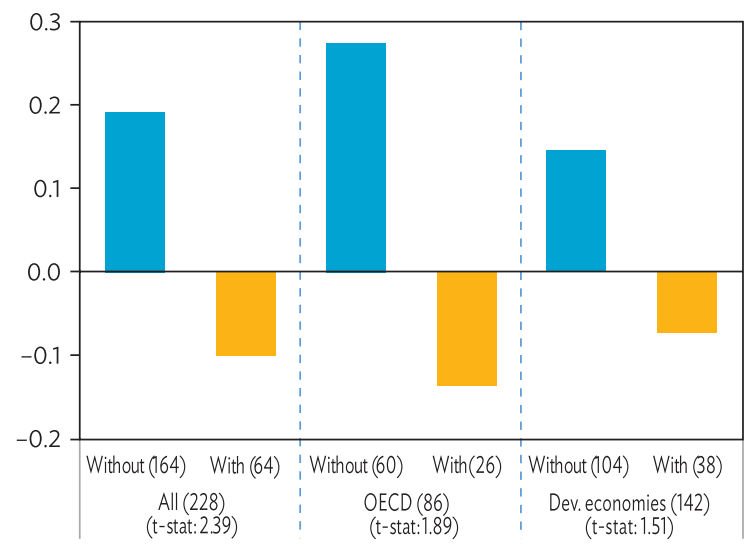

OECD = Organisation for Economic Co-operation and Development.

Notes: The data from Reinhart and Rogoff (2011) cover 125 country-decade pairs and include 58 banking crises, of which 30 are in OECD while 28 are in developing economies. In Laeven and Valencia (2012), data cover 228 country-decade pairs, which include 64 banking crises, of which 26 are in OECD and 38 are in developing economies. The number of observations is enclosed in parentheses after the labels.

Source: Authors' estimates. 
Table 2: Average Gross Domestic Product per Capita Growth-Periods of Negative Credit Skewness versus Periods of Positive Credit Skewness, 1971-2016

\begin{tabular}{lcccc}
\hline Economies & $\begin{array}{c}\text { Negative } \\
\text { Skewness }\end{array}$ & $\begin{array}{c}\text { Positive } \\
\text { Skewness }\end{array}$ & $\begin{array}{c}\text { Moderately or Highly } \\
\text { Negative Skewness }\end{array}$ & $\begin{array}{c}\text { Moderately or Highly } \\
\text { Positive Skewness }\end{array}$ \\
\hline RTW sample (1971-2000) & 3.92 & 3.17 & 3.28 & 3.08 \\
All & $(2.14)$ & $(1.76)$ & $(0.37)$ & $(0.24)$ \\
Developing economies & 4.06 & 3.62 & 3.65 & 3.40 \\
OECD & $(2.27)$ & $(2.13)$ & $(0.49)$ & $(0.42)$ \\
& 3.78 & 2.68 & 2.65 & 2.73 \\
RTW sample (1971-2016) & $(2.04)$ & $(1.03)$ & $(0.48)$ & $(0.20)$ \\
All & & & & 3.20 \\
Developing economies & 3.31 & 3.22 & 3.12 & $(0.23)$ \\
OECD & $(2.10)$ & $(2.10)$ & $(0.29)$ & 3.88 \\
& 4.03 & 4.00 & 3.80 & $(0.35)$ \\
\hline Extended sample (1971-2016) & $(1.99)$ & $(1.98)$ & $(0.32)$ & 2.42 \\
All & 2.69 & 2.30 & 1.87 & $(0.20)$ \\
\hline Developing economies & $(2.00)$ & $(1.38)$ & $(0.38)$ & 3.33 \\
OECD & 3.31 & 3.36 & & $(0.23)$ \\
& $(2.34)$ & $(2.26)$ & $(0.30)$ & 3.70 \\
& 3.68 & 3.87 & 3.99 & $(0.30)$ \\
\hline
\end{tabular}

OECD = Organisation for Economic Co-operation and Development, RTW = Ranciere, Tornell, and Westermann (2008).

Note: Figures in parentheses are standard deviations of growth rates.

Source: Authors' estimates.

\section{METHODOLOGY}

In this section, we introduce the econometric methodology used in our analysis. As in Ranciere, Tornell, and Westermann (2008), we extend a standard growth equation by including the three first moments of the distribution of real credit growth. Our baseline model for studying the link between credit skewness and economic growth is the following panel regression:

$$
y_{i t}=\beta_{\mu} \cdot \mu_{b c, i t}+\beta_{\sigma} \cdot \sigma_{b c, i t}+\beta_{s k} \cdot s k_{b c, i t}+\theta \cdot X_{i t}+\delta_{t}+\varepsilon_{i t}
$$

where $y_{i t}$ stands for average per capita GDP growth, and $\mu_{b c, i t}, \sigma_{b c, i t}$, and $s k_{b c, i t}$ represent the mean, standard deviation, and skewness of the growth rate of real credit to the private sector, respectively. We also include a vector of controls $X_{i t}$ and period dummies $\delta_{t}$. The error term is collected in $\varepsilon_{i t}$. Our set of controls is relatively narrow; it includes initial per capita GDP and the initial ratio of secondary schooling. We estimate this model by generalized least squares, using 10-year nonoverlapping windows. We run this regression for the two different samples detailed above. Using the extended sample, we run our baseline regression, both for the full sample and separately for the subsamples of advanced economies and developing economies. 
Subsequently, we extend the analysis to capture other potential mechanisms at work. We focus on two main alternative models. First, in the same spirit as Arcand, Berkes, and Panizza (2012), we test whether negative and positive skewness have different effects on growth. Second, along the lines of Bezemer (2012), we check whether skewness remains a sufficient statistic underlying the positive effect of finance on growth, even if it signals credit booms that have not been accompanied by a reduction of credit stocks following a bust. The idea is to test for the cleansing or creative destruction effect of credit reduction during a bust. These two extensions are described in detail in the remainder of this section.

\section{A. Nonlinearities: Positive versus Negative Skewness}

We study whether there is a role for nonlinearities by allowing the effects to differ depending on whether skewness is positive or negative. The underlying idea is that the relation between credit skewness and economic growth may differ depending on whether the skewness is positive or negative. The new regression is

$$
y_{i t}=\beta_{\mu} \cdot \mu_{b c, i t}+\beta_{\sigma} \cdot \sigma_{b c, i t}+\beta_{s k}^{P O S} \cdot s k_{b c, i t}^{P O S}+\beta_{s k}{ }^{N E G} \cdot s k_{b c, i t}{ }^{N E G}+\theta \cdot X_{i t}+\delta_{t}+\varepsilon_{i t}
$$

where $s k_{b c, i t}{ }^{P O S}$ is defined as the value of credit skewness if it is positive and zero otherwise, and $s k_{b c, i t}{ }^{N E G}$ is defined similarly for negative skewness.

\section{B. Negative Skewness and Credit Busts}

Underlying the arguments in Ranciere, Tornell, and Westermann (2008) is the idea that negative skewness is a proxy for a process of credit-driven creative destruction (see Bezemer 2012), leading to higher growth and welfare. In this subsection, we test this idea by checking whether it is the presence or absence of a cleansing effect associated with credit busts that determines the strength or weakness of subsequent growth dynamics. This is related to the argument in Caballero, Hoshi, and Kashyap (2008) and Philippon (2012) that an economy needs to undergo a period of credit deleveraging, during which balance sheets clear and the stock of credit falls, before economic activity can pick up again.

To carry on this analysis, we define an indicator that measures the extent of credit deleveraging. We calculate the growth of real credit to the private sector in a full decade. Defining any time period within a decade as $t_{j}$, we define cumulative credit growth as follows:

$$
C C G_{i d}=\sum_{j=1}^{j=10} b c_{i t_{j}}
$$

where $b c_{i t_{j}}$ stands for the growth rate of real credit of economy $i$ in year $t_{j}$ within decade $d$.

Using the newly built $C C G_{i d}$, we extend our benchmark regression as follows:

$$
\begin{aligned}
& y_{i t}=\beta_{\mu} \cdot \mu_{b c, i t}+\beta_{\sigma} \cdot \sigma_{b c, i t}+\beta_{s k} \cdot s k_{b c, i t}+\beta_{s k}{ }^{C C G} \cdot s k_{b c, i t} \cdot C C G_{i d}+\gamma \cdot C C G_{i d} \\
& +\theta \cdot X_{i t}+\delta_{t}+\varepsilon_{i t}
\end{aligned}
$$

where $\mu_{b c, i t}, \sigma_{b c, i t}$, and $s k_{b c, i t}$ represent the mean, standard deviation, and skewness of the growth rate of real credit to the private sector, and $X_{i t}$ contains additional controls. The only new elements of the regression are the cumulative credit growth variable and its interaction with credit skewness. 
This regression helps us assess whether the relation between skewness and growth depends on the extent of cumulative credit growth if we look at the sign of $\beta_{s k}{ }^{C C G}$. If this coefficient is negative, then an increase in credit skewness can be beneficial for growth if it is accompanied by an eventual credit reduction. If this coefficient is negative, a credit decline may be less damaging when skewness is positive.

\section{Nonlinearities and Credit Deleveraging}

Finally, we combine the two previous exercises and study whether the extent of credit accumulation or reduction affects the relation between skewness and growth differently when skewness is positive versus when it is negative. Using $C C G_{i d}, s k_{b c, i t}{ }^{N E G}$, and $s k_{b c, i t}{ }^{P O S}$, we define the following model:

$$
\begin{gathered}
y_{i t}=\beta_{\mu} \cdot \mu_{b c, i t}+\beta_{\sigma} \cdot \sigma_{b c, i t}+\beta_{s k}{ }^{P O S} \cdot s k_{b c, i t}{ }^{P O S}+\alpha_{s k}{ }^{P O S} \cdot s k_{b c, i t}{ }^{P O S} \cdot C C G_{i d} \\
+\beta_{s k}{ }^{N E G} \cdot s k_{b c, i t}{ }^{N E G}+\alpha_{s k}^{N E G} \cdot s k_{b c, i t}{ }^{N E G} \cdot C C G_{i d}+\theta \cdot X_{i t}+\delta \cdot C C G_{i d}+\delta_{t}+\varepsilon_{i t}
\end{gathered}
$$

where $\mu_{b c, i t}$ and $\sigma_{b c, i t}$ represent the mean and standard deviation. As in equation (2), the skewness of the growth rate of real credit to the private sector is separated into positive and negative values, and $X_{i t}$ contains additional controls. Basically, we are separating our economy-decade observations into two groups - those with negative skewness and those with positive skewness-and allow the effect within these two groups to depend on the credit change within the decade, captured by coefficients $\alpha_{s k}{ }^{N E G}$ and $\alpha_{s k}^{P O S}$ as follows:

$$
\frac{\partial y_{i t}}{\partial s k_{b c, i t}{ }^{P O S}}=\beta_{s k}{ }^{P O S}+\alpha_{s k}^{P O S} \cdot C C G_{i d}
$$

For any given level of positive (negative) skewness, whether a reduction in real credit leads to higher or lower growth depends on the sign of $\alpha_{s k}{ }^{P O S}\left(\alpha_{s k}{ }^{N E G)}\right)$. If $\alpha_{s k}{ }^{P O S}<0$, then for any given level of positive skewness, its effect is stronger whenever there has been credit deleveraging in the period.

\section{EMPIRICAL RESULTS}

In this section, we report and discuss our empirical findings. As a first step, we estimate equation (1) using the RTW sample, both for the full sample and separately for the OECD and developing economy subsamples. Using this dataset, we also define subsamples in the time dimension and estimate the model for the following periods: 1971-2000 (which is the closest to Ranciere, Tornell, and Westermann [2008]); 2001-2016; and 1971-2016. The results are presented in Table 3.

\section{A. Ranciere, Tornell, and Westermann (2008) Sample}

Regression results in Table 3 show that higher credit growth is associated with higher economic growth, which is consistent with much of the empirical literature on the finance-growth nexus (King and Levine 1993, Demirgüç-Kunt and Levine 2008). We also find that higher variability in credit growth is linked with lower economic growth.

Table 3 also shows a significant and negative link between skewness of credit growth and economic growth in the full sample. The relationship holds even after controlling for mean growth in private credit and the variance of credit growth. This is observed during 1971-2000 (column [1]) and 1971-2016 (column [3]), although the magnitudes of coefficients vary with time periods. For 
specifications covering the earlier period between 1971 and 2000, the coefficient is -0.44 for the full sample in column (1), which suggests that a one-unit decrease in skewness (from 0 to -1 ) is associated with a $0.44 \%$ increase in annual per capita GDP growth. The association between growth and skewness is significant in advanced economies (column [4]) but not in developing economies (column [7]). For the full sample, in the specifications covering a longer time period, 1971-2016, the absolute value of the coefficient declines (column [4]), suggesting that the correlation between systemic risk and growth may have diminished in more recent periods. In fact, the coefficient of credit skewness is insignificant for the period 2001-2016 (column [2]). For advanced economies, the relationship between skewness and growth is negative and significant prior to-but not after-2000, as shown in columns (4) and (5), respectively.

\section{B. Extended Sample}

Next, we reproduce the analysis and estimate equation (1) for a larger sample of economies, with the results shown in Table 4a. We find that the coefficient for credit skewness is no longer significant (column [1]). In an attempt to understand why the results change when we expand the economy sample, we conduct a number of alternative analyses. First, we examine whether credit skewness may have a different effect by decade. We do this by introducing interaction variables between skewness and time dummy variables representing the different decades, with the results shown in columns (2), (7), and (12) of Table 4a. We find these variables to be significant only for the 1970s for the full sample (column [2]) and the developing economy subsample (column [12]). For advanced economies, a negative correlation between skewness and credit growth is significant only in the 1990s (column [7]). Since 2000, lower skewness is no longer associated with higher growth. This shows that financial disruptions may have been positively associated with growth in the pre-2000 period, but financial disruptions were no longer conducive for growth after 2000. This may be linked to the differences between the type of financial risks that materialized before and after 2000 .

We then test for equation (2), which allows for negative and positive skewness to have different effects. These results are in column (3) for the full sample, column (8) for OECD economies, and column (13) for developing economies in Table 4a. For the full sample, we do not find any differential effect between positive and negative skewness, but for advanced economies there appears to be a negative correlation between positive skewness and economic growth. This suggests that positive skewness may contribute to slower growth in advanced economies. However, negative skewness is not associated with faster growth.

Next, we examine the interaction between skewness and credit growth metrics, as specified in equation (3). Here we want to test whether the relation between skewness and growth depends on the extent of cumulative credit growth. In columns (4), (9), and (14) of Table 4a, we find a significant and negative coefficient for this variable in the full sample and advanced economy subsample. The evidence for the full sample is that positive credit skewness can be beneficial for growth when there is actual credit deleveraging. Since the coefficient of the interaction between skewness and credit growth is negative, positive skewness interacted with a decline in credit tends to promote growth. However, the interaction of negative skewness and credit decline is associated with lower growth.

Finally, we report the results of analyzing the interaction between skewness, separate for positive and negative, and the cumulative credit growth, as specified earlier in equation (4). As explained in the methodological section, here we look at nonlinearities and credit deleveraging. After separating our economy-decade observations into those with negative skewness and those with 
positive skewness, and allowing the effect within these two groups to depend on credit change within the decade, we do find that the coefficient of the interaction between negative skewness and total credit is insignificant, as shown in columns (5), (10), and (15) of Table 4a. However, the coefficient of negative skewness alone is significant in developing economies (column [15]), but not in advanced economies (column [10]). We also find that the coefficient of positive skewness for developing economies is positive and significant, and that the interaction between positive skewness and credit change is negative. As we indicated earlier, this implies that for any given level of positive skewness, its effect is stronger when there has been credit deleveraging.

A possible reason why the coefficient of negative skewness is not significant for advanced economies is that they are characterized by positive skewness, which implies less credit busts but deliver a slower path of growth. On the other hand, developing economies are subject to more destructive credit busts, which in exchange may allow for more economic dynamism. From Table 1, we can see that developing economies experienced more positive skewness than negative skewness, indicating greater tendency for a safe mode, relative to advanced economies. The results thus seem to imply that benefits from negative skewness (credit booms), in the form of higher economic growth, outweigh the risks. In the case of advanced economies, stable and steady credit growth that is usually characterized by positive skewness may be more beneficial than credit booms. As Ranciere, Tornell, and Westermann (2008) emphasize, systemic risk-taking is not a growth strategy that can be pursued forever. An economy that becomes rich enough must move toward a safe path.

Turning to the results for OECD economies in column (10) of Table 4a, note that the coefficient of positive skewness is no longer significant once we control for credit change. However, the coefficient of positive skewness interacted with credit change is negative and significant. This implies that positive skewness interacting with a credit decline is growth enhancing, while the interaction of positive skewness with a credit increase is growth reducing.

In Table 4b, we control for fixed effects to check for the robustness of our results. In the baseline equation for the full economy sample, credit skewness remains insignificant (column [1]). By decade, we find negative skewness to be more growth promoting relative to the base period (2010-2016) in most periods except the 1990s (column [2]). For advanced economies, results are consistent with the generalized least squares model, with negative skewness prior to 2000 s more growth promoting relative to the base period (column [7]). For developing economies, results in column (12) show that negative skewness was growth promoting in the 1970s, 1980s, and 2000s. Table 4b also shows that after controlling for fixed effects, positive skewness may be associated with higher growth in the entire sample. However, the result for negative skewness is insignificant, as seen in columns (3) and (5).

Another way to check for robustness is through cross-section regressions, the results of which are shown in Table 4c. The baseline results show that negative skewness is associated with faster growth for the full economy sample, OECD subsample, and developing economy subsample, as shown in columns (1), (5), and (9), respectively. However, when we control for nonlinearities, in the full sample and developing economy subsample positive skewness is associated with slower growth while negative skewness does not seem to matter anymore (columns [2] and [10]). For advanced economies, negative skewness continues to be associated with higher growth (column [6]), even after controlling for credit change (column [7]) and the interaction of credit change with skewness (column [8]). This seems to suggest that for the entire sample period (1971-2016) negative skewness has been positively associated with growth in advanced economies, although there is a possibility that in some decades negative skewness may not actually be linked to higher growth. 
Table 3: Skewness and Growth (Dependent Variable-Real Gross Domestic Product per Capita Growth)

\begin{tabular}{|c|c|c|c|c|c|c|c|c|c|}
\hline \multirow[b]{3}{*}{ Variables } & \multicolumn{3}{|c|}{ Full Sample } & \multicolumn{3}{|c|}{ OECD } & \multicolumn{3}{|c|}{ Developing Economies } \\
\hline & & & & & & (6) & (7) & & \\
\hline & $1971-2000$ & 2001-2016 & $1971-2016$ & $1971-2000$ & 2001-2016 & $1971-2016$ & $1971-2000$ & 2001-2016 & 1971-2016 \\
\hline Credit growth (mean) & $\begin{array}{l}0.160^{* * *} \\
(0.019)\end{array}$ & $\begin{array}{l}0.115^{* * *} \\
(0.017)\end{array}$ & $\begin{array}{l}0.161^{* * *} \\
(0.015)\end{array}$ & $\begin{array}{l}0.199^{* * *} \\
(0.038)\end{array}$ & $\begin{array}{l}0.090^{* * *} \\
(0.023)\end{array}$ & $\begin{array}{l}0.135^{\text {***}} \\
(0.025)\end{array}$ & $\begin{array}{l}0.141^{* * *} \\
(0.027)\end{array}$ & $\begin{array}{l}0.061^{* * *} \\
(0.019)\end{array}$ & $\begin{array}{l}0.101^{* * *} \\
(0.019)\end{array}$ \\
\hline Credit growth (SD) & $\begin{array}{l}-0.033^{* * *} \\
(0.009)\end{array}$ & $\begin{array}{r}-0.009 \\
(0.011)\end{array}$ & $\begin{array}{l}-0.039^{* * *} \\
(0.008)\end{array}$ & $\begin{array}{l}-0.039^{* * *} \\
(0.014)\end{array}$ & $\begin{array}{c}-0.001 \\
(0.014)\end{array}$ & $\begin{array}{l}-0.029^{* * *} \\
(0.011)\end{array}$ & $\begin{array}{l}-0.055^{* *} \\
(0.021)\end{array}$ & $\begin{array}{c}-0.034^{*} \\
(0.018)\end{array}$ & $\begin{array}{l}-0.055^{* * *} \\
(0.019)\end{array}$ \\
\hline Credit growth (SKW) & $\begin{array}{l}-0.439^{* * *} \\
(0.114)\end{array}$ & $\begin{array}{l}-0.027 \\
(0.099)\end{array}$ & $\begin{array}{l}-0.175^{* *} \\
(0.086)\end{array}$ & $\begin{array}{l}-0.491^{* * *} \\
(0.164)\end{array}$ & $\begin{array}{r}-0.079 \\
(0.101)\end{array}$ & $\begin{array}{c}-0.138 \\
(0.105)\end{array}$ & $\begin{array}{l}-0.329 \\
(0.202)\end{array}$ & $\begin{array}{r}-0.079 \\
(0.152)\end{array}$ & $\begin{array}{c}-0.158 \\
(0.163)\end{array}$ \\
\hline Initial income per capita & $\begin{array}{l}0.102^{* * *} \\
(0.039)\end{array}$ & $\begin{array}{l}-0.118^{* * *} \\
(0.043)\end{array}$ & $\begin{array}{c}0.010 \\
(0.045)\end{array}$ & $\begin{array}{c}0.100 \\
(0.070)\end{array}$ & $\begin{array}{c}-0.171^{* *} \\
(0.070)\end{array}$ & $\begin{array}{c}-0.071 \\
(0.066)\end{array}$ & $\begin{array}{c}0.169^{*} \\
(0.086)\end{array}$ & $\begin{array}{l}0.289^{* * *} \\
(0.054)\end{array}$ & $\begin{array}{l}0.202^{* * *} \\
(0.077)\end{array}$ \\
\hline Initial schooling & $\begin{array}{l}-0.023^{* * *} \\
(0.004)\end{array}$ & $\begin{array}{l}-0.026^{* * *} \\
(0.004)\end{array}$ & $\begin{array}{l}-0.023^{* * *} \\
(0.003)\end{array}$ & $\begin{array}{l}-0.014 \\
(0.009)\end{array}$ & $\begin{array}{l}-0.013^{* *} \\
(0.006)\end{array}$ & $\begin{array}{l}-0.013^{* *} \\
(0.007)\end{array}$ & $\begin{array}{l}-0.024^{* * *} \\
(0.009)\end{array}$ & $\begin{array}{l}-0.021^{* * *} \\
(0.004)\end{array}$ & $\begin{array}{l}-0.018^{* * *} \\
(0.007)\end{array}$ \\
\hline Time dummy, 1971-1980 & $\begin{array}{c}0.050 \\
(0.203)\end{array}$ & & $\begin{array}{c}0.379 \\
(0.233)\end{array}$ & $\begin{array}{r}0.296 \\
(0.331)\end{array}$ & & $\begin{array}{l}1.137^{* * *} \\
(0.333)\end{array}$ & $\begin{array}{c}0.119 \\
(0.452)\end{array}$ & & $\begin{array}{c}0.418 \\
(0.568)\end{array}$ \\
\hline Time dummy, 1981-1990 & $\begin{array}{c}-0.193 \\
(0.179)\end{array}$ & & $\begin{array}{r}0.045 \\
(0.216)\end{array}$ & $\begin{array}{c}-0.080 \\
(0.254)\end{array}$ & & $\begin{array}{c}0.523^{*} \\
(0.288)\end{array}$ & $\begin{array}{c}-0.590 \\
(0.380)\end{array}$ & & $\begin{array}{l}-0.613 \\
(0.504)\end{array}$ \\
\hline Time dummy, 1991-2000 & & $\begin{array}{c}-0.175 \\
(0.134)\end{array}$ & $\begin{array}{r}-0.082 \\
(0.216)\end{array}$ & & $\begin{array}{r}-0.057 \\
(0.141)\end{array}$ & $\begin{array}{c}-0.014 \\
(0.253)\end{array}$ & & $\begin{array}{c}-0.277 \\
(0.182)\end{array}$ & $\begin{array}{c}-0.050 \\
(0.443)\end{array}$ \\
\hline Time dummy, 2001-2010 & & & $\begin{array}{c}0.375^{*} \\
(0.211)\end{array}$ & & & $\begin{array}{l}0.734^{* * *} \\
(0.251)\end{array}$ & & & $\begin{array}{l}-0.015 \\
(0.528)\end{array}$ \\
\hline Constant & $\begin{array}{r}1.733^{*} \\
(0.928)\end{array}$ & $\begin{array}{l}7.605^{* * *} \\
(1.076)\end{array}$ & $\begin{array}{l}3.795^{* * *} \\
(1.052)\end{array}$ & $\begin{array}{c}0.600 \\
(2.115)\end{array}$ & $\begin{array}{l}7.292^{* * *} \\
(1.953)\end{array}$ & $\begin{array}{l}4.525^{* *} \\
(2.023)\end{array}$ & $\begin{array}{c}0.850 \\
(1.995)\end{array}$ & $\begin{array}{c}-1.548 \\
(1.422)\end{array}$ & $\begin{array}{c}0.103 \\
(1.798)\end{array}$ \\
\hline Observations & 120 & 74 & 197 & 58 & 38 & 98 & 62 & 36 & 99 \\
\hline Number of economies & 44 & 37 & 44 & 21 & 19 & 21 & 23 & 18 & 23 \\
\hline
\end{tabular}

SD = standard deviation, SKW = skewness.

Notes: Standard errors in parentheses. ${ }^{* *}=p<0.01,{ }^{* *}=p<0.05$, and ${ }^{*}=p<0.1$.

Source: Authors' estimates. 
Table 4a: Skewness and Growth of Extended Sample, 1971-2016 (Panel Generalized Least Squares)

\begin{tabular}{|c|c|c|c|c|c|}
\hline \multirow[b]{2}{*}{ Variables } & \multicolumn{5}{|c|}{ Full Sample } \\
\hline & $\begin{array}{c}\text { (1) } \\
\text { Baseline }\end{array}$ & $\begin{array}{c}\text { (2) } \\
\text { Time } \\
\text { Interactions }\end{array}$ & $\begin{array}{c}\text { (3) } \\
\text { Positive or } \\
\text { Negative SKW }\end{array}$ & $\begin{array}{c}\text { (4) } \\
\text { SKW and } \\
\text { Credit Change }\end{array}$ & $\begin{array}{c}\text { (5) } \\
\text { Positive or } \\
\text { Negative SKW and } \\
\text { Credit Change }\end{array}$ \\
\hline Credit growth (mean) & $\begin{array}{l}0.131^{* * *} \\
(0.010)\end{array}$ & $\begin{array}{l}0.183^{* * *} \\
(0.024)\end{array}$ & $\begin{array}{l}0.133^{* * *} \\
(0.011)\end{array}$ & $\begin{array}{l}0.177^{* * *} \\
(0.028)\end{array}$ & $\begin{array}{l}0.164^{* * *} \\
(0.027)\end{array}$ \\
\hline Credit growth (SD) & $\begin{array}{l}-0.066^{* * *} \\
(0.007)\end{array}$ & $\begin{array}{c}0.052 \\
(0.034)\end{array}$ & $\begin{array}{l}-0.064^{* * *} \\
(0.008)\end{array}$ & $\begin{array}{l}-0.064^{* * *} \\
(0.009)\end{array}$ & $\begin{array}{l}-0.054^{* * *} \\
(0.010)\end{array}$ \\
\hline Credit growth (SKW) & $\begin{array}{l}-0.027 \\
(0.065)\end{array}$ & $\begin{array}{r}0.068 \\
(0.221)\end{array}$ & & $\begin{array}{c}0.043 \\
(0.095)\end{array}$ & \\
\hline Credit growth mean x 1971-1980 & & $\begin{array}{l}-0.072 \\
(0.047)\end{array}$ & & & \\
\hline Credit growth mean x 1981-1990 & & $\begin{array}{c}0.012 \\
(0.037)\end{array}$ & & & \\
\hline Credit growth mean x 1991-2000 & & $\begin{array}{l}-0.098^{* * *} \\
(0.030)\end{array}$ & & & \\
\hline Credit growth mean x 2001-2010 & & $\begin{array}{l}-0.093^{* * *} \\
(0.031)\end{array}$ & & & \\
\hline Credit growth SD x 1971-1980 & & $\begin{array}{l}-0.082^{* *} \\
(0.040)\end{array}$ & & & \\
\hline Credit growth SD x 1981-1990 & & $\begin{array}{l}-0.128^{* * *} \\
(0.039)\end{array}$ & & & \\
\hline Credit growth SD x 1991-2000 & & $\begin{array}{l}-0.117^{* * *} \\
(0.036)\end{array}$ & & & \\
\hline Credit growth SD x 2001-2010 & & $\begin{array}{l}-0.045 \\
(0.039)\end{array}$ & & & \\
\hline Credit growth SKW x 1971-1980 & & $\begin{array}{l}-0.763^{* *} \\
(0.345)\end{array}$ & & & \\
\hline Credit growth SKW x 1981-1990 & & $\begin{array}{l}-0.259 \\
(0.306)\end{array}$ & & & \\
\hline Credit growth SKW x 1991-2000 & & $\begin{array}{l}-0.000 \\
(0.270)\end{array}$ & & & \\
\hline Credit growth SKW x 2001-2010 & & $\begin{array}{l}-0.038 \\
(0.252)\end{array}$ & & & \\
\hline Positive SKW & & & $\begin{array}{r}-0.033 \\
(0.112)\end{array}$ & & $\begin{array}{c}0.263 \\
(0.162)\end{array}$ \\
\hline Negative SKW & & & $\begin{array}{r}-0.053 \\
(0.177)\end{array}$ & & $\begin{array}{l}-0.220 \\
(0.196)\end{array}$ \\
\hline SKW $x$ credit change & & & & $\begin{array}{l}-0.003^{* *} \\
(0.001)\end{array}$ & \\
\hline Credit change & & & & $\begin{array}{c}-0.005 \\
(0.003)\end{array}$ & $\begin{array}{c}0.001 \\
(0.004)\end{array}$ \\
\hline Positive SKW x credit change & & & & & $\begin{array}{l}-0.006^{* * *} \\
(0.002)\end{array}$ \\
\hline Negative SKW x credit change & & & & & $\begin{array}{c}0.004 \\
(0.007)\end{array}$ \\
\hline Observations & 328 & 328 & 328 & 328 & 328 \\
\hline Number of economies & 82 & 82 & 82 & 82 & 82 \\
\hline
\end{tabular}


Table 4a continued

\begin{tabular}{|c|c|c|c|c|c|}
\hline \multirow[b]{2}{*}{ Variables } & \multicolumn{5}{|c|}{ OECD } \\
\hline & $\begin{array}{c}\text { (6) } \\
\text { Baseline }\end{array}$ & $\begin{array}{c}\text { (7) } \\
\text { Time } \\
\text { Interactions }\end{array}$ & $\begin{array}{c}\text { (8) } \\
\text { Positive or } \\
\text { Negative SKW }\end{array}$ & $\begin{array}{c}\text { (9) } \\
\text { SKW and Credit } \\
\text { Change }\end{array}$ & $\begin{array}{c}\text { (10) } \\
\text { Positive or } \\
\text { Negative SKW and } \\
\text { Credit Change }\end{array}$ \\
\hline Credit growth (mean) & $\begin{array}{l}0.136^{* * *} \\
(0.022)\end{array}$ & $\begin{array}{c}0.153^{* * *} \\
(0.049)\end{array}$ & $\begin{array}{l}0.138^{* * *} \\
(0.023)\end{array}$ & $\begin{array}{c}0.037 \\
(0.048)\end{array}$ & $\begin{array}{c}0.059 \\
(0.049)\end{array}$ \\
\hline Credit growth (SD) & $\begin{array}{l}-0.030^{* * *} \\
(0.010)\end{array}$ & $\begin{array}{l}0.438^{* * *} \\
(0.117)\end{array}$ & $\begin{array}{l}-0.024^{* *} \\
(0.011)\end{array}$ & $\begin{array}{c}0.006 \\
(0.014)\end{array}$ & $\begin{array}{c}0.003 \\
(0.015)\end{array}$ \\
\hline Credit growth (SKW) & $\begin{array}{c}-0.186^{*} \\
(0.096)\end{array}$ & $\begin{array}{c}0.268 \\
(0.373)\end{array}$ & & $\begin{array}{c}0.156 \\
(0.149)\end{array}$ & \\
\hline Credit growth mean x 1971-1980 & & $\begin{array}{c}0.011 \\
(0.081)\end{array}$ & & & \\
\hline Credit growth mean x 1981-1990 & & $\begin{array}{c}0.049 \\
(0.096)\end{array}$ & & & \\
\hline Credit growth mean x 1991-2000 & & $\begin{array}{l}-0.005 \\
(0.064)\end{array}$ & & & \\
\hline Credit growth mean x 2001-2010 & & $\begin{array}{l}-0.060 \\
(0.067)\end{array}$ & & & \\
\hline Credit growth SD x 1971-1980 & & $\begin{array}{l}-0.548^{* * *} \\
(0.122)\end{array}$ & & & \\
\hline Credit growth SD x 1981-1990 & & $\begin{array}{l}-0.530^{* * *} \\
(0.122)\end{array}$ & & & \\
\hline Credit growth SD x 1991-2000 & & $\begin{array}{l}-0.457^{* * *} \\
(0.118)\end{array}$ & & & \\
\hline Credit growth SD x 2001-2010 & & $\begin{array}{l}-0.437^{* * *} \\
(0.120)\end{array}$ & & & \\
\hline Credit growth SKW x 1971-1980 & & $\begin{array}{c}-0.182 \\
(0.501)\end{array}$ & & & \\
\hline Credit growth SKW x 1981-1990 & & $\begin{array}{c}-0.766 \\
(0.490)\end{array}$ & & & \\
\hline Credit growth SKW x 1991-2000 & & $\begin{array}{c}-0.901^{* *} \\
(0.447)\end{array}$ & & & \\
\hline Credit growth SKW x 2001-2010 & & $\begin{array}{c}-0.182 \\
(0.416)\end{array}$ & & & \\
\hline Positive SKW & & & $\begin{array}{l}-0.425^{\text {***}} \\
(0.151)\end{array}$ & & $\begin{array}{c}0.132 \\
(0.201)\end{array}$ \\
\hline Negative SKW & & & $\begin{array}{c}0.024 \\
(0.237)\end{array}$ & & $\begin{array}{c}0.131 \\
(0.270)\end{array}$ \\
\hline SKW $\times$ credit change & & & & $\begin{array}{l}-0.008^{* * *} \\
(0.002)\end{array}$ & \\
\hline Credit change & & & & $\begin{array}{c}0.012^{* *} \\
(0.006)\end{array}$ & $\begin{array}{l}0.018^{* * *} \\
(0.007)\end{array}$ \\
\hline Positive SKW x credit change & & & & & $\begin{array}{l}-0.011^{* * *} \\
(0.003)\end{array}$ \\
\hline Negative SKW $x$ credit change & & & & & $\begin{array}{c}0.003 \\
(0.007)\end{array}$ \\
\hline Observations & 114 & 114 & 114 & 114 & 114 \\
\hline Number of economies & 26 & 26 & 26 & 26 & 26 \\
\hline
\end{tabular}




\begin{tabular}{|c|c|c|c|c|c|}
\hline \multirow[b]{2}{*}{ Variables } & \multicolumn{5}{|c|}{ Developing Economies } \\
\hline & $\begin{array}{c}\text { (11) } \\
\text { Baseline }\end{array}$ & $\begin{array}{c}\text { (12) } \\
\text { Time } \\
\text { Interactions }\end{array}$ & $\begin{array}{c}\text { (13) } \\
\text { Positive or } \\
\text { Negative SKW }\end{array}$ & $\begin{array}{c}\text { (14) } \\
\text { SKW and Credit } \\
\text { Change }\end{array}$ & $\begin{array}{c}\text { (15) } \\
\text { Positive or } \\
\text { Negative SKW and } \\
\text { Credit Change }\end{array}$ \\
\hline Credit growth (mean) & $\begin{array}{l}0.114^{* * *} \\
(0.013)\end{array}$ & $\begin{array}{l}0.171^{* * *} \\
(0.032)\end{array}$ & $\begin{array}{l}0.116^{* * *} \\
(0.013)\end{array}$ & $\begin{array}{l}0.217^{* * *} \\
(0.041)\end{array}$ & $\begin{array}{l}0.168^{* * *} \\
(0.033)\end{array}$ \\
\hline Credit growth (SD) & $\begin{array}{l}-0.077^{* * *} \\
(0.011)\end{array}$ & $\begin{array}{c}0.035 \\
(0.043)\end{array}$ & $\begin{array}{l}-0.078^{* * *} \\
(0.011)\end{array}$ & $\begin{array}{l}-0.092^{* * *} \\
(0.013)\end{array}$ & $\begin{array}{l}-0.066^{* * *} \\
(0.012)\end{array}$ \\
\hline Credit growth (SKW) & $\begin{array}{c}-0.017 \\
(0.101)\end{array}$ & $\begin{array}{c}0.448 \\
(0.274)\end{array}$ & & $\begin{array}{c}0.126 \\
(0.143)\end{array}$ & \\
\hline Credit growth mean x 1971-1980 & & $\begin{array}{c}-0.029 \\
(0.061)\end{array}$ & & & \\
\hline Credit growth mean x 1981-1990 & & $\begin{array}{c}0.047 \\
(0.046)\end{array}$ & & & \\
\hline Credit growth mean x 1991-2000 & & $\begin{array}{l}-0.099^{* * *} \\
(0.037)\end{array}$ & & & \\
\hline Credit growth mean x 2001-2010 & & $\begin{array}{l}-0.082^{* *} \\
(0.040)\end{array}$ & & & \\
\hline Credit growth SD x 1971-1980 & & $\begin{array}{l}-0.080 \\
(0.053)\end{array}$ & & & \\
\hline Credit growth SD x 1981-1990 & & $\begin{array}{c}-0.082 \\
(0.058)\end{array}$ & & & \\
\hline Credit growth SD x 1991-2000 & & $\begin{array}{l}-0.128^{* * *} \\
(0.044)\end{array}$ & & & \\
\hline Credit growth SD x 2001-2010 & & $\begin{array}{l}-0.066 \\
(0.052)\end{array}$ & & & \\
\hline Credit growth SKW x 1971-1980 & & $\begin{array}{l}-1.474^{* * *} \\
(0.533)\end{array}$ & & & \\
\hline Credit growth SKW x 1981-1990 & & $\begin{array}{c}-0.193 \\
(0.387)\end{array}$ & & & \\
\hline Credit growth SKW x 1991-2000 & & $\begin{array}{c}-0.448 \\
(0.324)\end{array}$ & & & \\
\hline Credit growth SKW x 2001-2010 & & $\begin{array}{l}-0.341 \\
(0.308)\end{array}$ & & & \\
\hline Positive SKW & & & $\begin{array}{c}0.149 \\
(0.163)\end{array}$ & & $\begin{array}{l}0.664^{* *} \\
(0.281)\end{array}$ \\
\hline Negative SKW & & & $\begin{array}{c}-0.350 \\
(0.257)\end{array}$ & & $\begin{array}{c}-0.509^{*} \\
(0.267)\end{array}$ \\
\hline SKW $x$ credit change & & & & $\begin{array}{c}-0.002 \\
(0.002)\end{array}$ & \\
\hline Credit change & & & & $\begin{array}{l}-0.013^{* * *} \\
(0.005)\end{array}$ & $\begin{array}{c}-0.002 \\
(0.005)\end{array}$ \\
\hline Positive SKW x credit change & & & & & $\begin{array}{l}-0.008^{* *} \\
(0.004)\end{array}$ \\
\hline Negative SKW x credit change & & & & & $\begin{array}{c}0.003 \\
(0.004)\end{array}$ \\
\hline Observations & 214 & 214 & 214 & 214 & 214 \\
\hline Number of economies & 56 & 56 & 56 & 56 & 56 \\
\hline
\end{tabular}

OECD = Organisation for Economic Co-operation and Development, $\mathrm{SD}=$ standard deviation, $\mathrm{SKW}=$ skewness.

Notes: Standard errors are in parentheses. ${ }^{* *}=p<0.01,{ }^{* *}=p<0.05$, and ${ }^{*}=p<0.1$. Coefficients of the constant, time dummy variables, initial gross domestic product per capita, and initial schooling are not reported here.

Source: Authors' estimates. 
Table 4b: Skewness and Growth of Extended Sample, 1971-2016 (Fixed Effects)

\begin{tabular}{|c|c|c|c|c|c|}
\hline \multirow[b]{2}{*}{ Variables } & \multicolumn{5}{|c|}{ Full Sample } \\
\hline & $\begin{array}{c}\text { (1) } \\
\text { Baseline }\end{array}$ & $\begin{array}{c}\text { (2) } \\
\text { Time } \\
\text { Interactions }\end{array}$ & $\begin{array}{c}\text { (3) } \\
\text { Positive or } \\
\text { Negative SKW }\end{array}$ & $\begin{array}{c}\text { (4) } \\
\text { SKW and Credit } \\
\text { Change }\end{array}$ & $\begin{array}{c}\text { (5) } \\
\text { Positive or } \\
\text { Negative SKW and } \\
\text { Credit Change }\end{array}$ \\
\hline Credit growth (mean) & $\begin{array}{l}0.097^{* * *} \\
(0.014)\end{array}$ & $\begin{array}{l}0.146^{* * *} \\
(0.044)\end{array}$ & $\begin{array}{l}0.097^{* * *} \\
(0.014)\end{array}$ & $\begin{array}{l}0.199^{* * *} \\
(0.043)\end{array}$ & $\begin{array}{l}0.172^{* * *} \\
(0.047)\end{array}$ \\
\hline Credit growth (SD) & $\begin{array}{l}-0.059^{* * *} \\
(0.020)\end{array}$ & $\begin{array}{r}0.118^{* *} \\
(0.052)\end{array}$ & $\begin{array}{l}-0.064^{* * *} \\
(0.020)\end{array}$ & $\begin{array}{l}-0.078^{* * *} \\
(0.021)\end{array}$ & $\begin{array}{l}-0.082^{* * *} \\
(0.021)\end{array}$ \\
\hline Credit growth (SKW) & $\begin{array}{c}0.161 \\
(0.123)\end{array}$ & $\begin{array}{l}0.815^{* *} \\
(0.333)\end{array}$ & & $\begin{array}{c}0.223 \\
(0.199)\end{array}$ & \\
\hline Credit growth mean x 1971-1980 & & $\begin{array}{l}-0.185^{* * *} \\
(0.067)\end{array}$ & & & \\
\hline Credit growth mean x 1981-1990 & & $\begin{array}{l}-0.025 \\
(0.075)\end{array}$ & & & \\
\hline Credit growth mean x 1991-2000 & & $\begin{array}{l}-0.119^{* *} \\
(0.054)\end{array}$ & & & \\
\hline Credit growth mean x 2001-2010 & & $\begin{array}{l}-0.048 \\
(0.053)\end{array}$ & & & \\
\hline Credit growth SD x 1971-1980 & & $\begin{array}{l}-0.125^{* *} \\
(0.057)\end{array}$ & & & \\
\hline Credit growth SD x 1981-1990 & & $\begin{array}{l}-0.183^{* * *} \\
(0.062)\end{array}$ & & & \\
\hline Credit growth SD x 1991-2000 & & $\begin{array}{l}-0.160^{* * *} \\
(0.048)\end{array}$ & & & \\
\hline Credit growth SD x 2001-2010 & & $\begin{array}{l}-0.090 \\
(0.073)\end{array}$ & & & \\
\hline Credit growth SKW x 1971-1980 & & $\begin{array}{l}-0.902^{*} \\
(0.512)\end{array}$ & & & \\
\hline Credit growth SKW x 1981-1990 & & $\begin{array}{l}-0.838^{*} \\
(0.448)\end{array}$ & & & \\
\hline Credit growth SKW x 1991-2000 & & $\begin{array}{l}-0.335 \\
(0.411)\end{array}$ & & & \\
\hline Credit growth SKW x 2001-2010 & & $\begin{array}{l}-0.943^{* *} \\
(0.390)\end{array}$ & & & \\
\hline Positive SKW & & & $\begin{array}{l}0.460^{*} \\
(0.236)\end{array}$ & & $\begin{array}{l}0.627^{*} \\
(0.367)\end{array}$ \\
\hline Negative SKW & & & $\begin{array}{l}-0.259 \\
(0.207)\end{array}$ & & $\begin{array}{l}-0.230 \\
(0.211)\end{array}$ \\
\hline SKW $\times$ credit change & & & & $\begin{array}{l}-0.001 \\
(0.002)\end{array}$ & \\
\hline Credit change & & & & $\begin{array}{l}-0.014^{* *} \\
(0.005)\end{array}$ & $\begin{array}{c}-0.012^{*} \\
(0.006)\end{array}$ \\
\hline Positive SKW x credit change & & & & & $\begin{array}{l}-0.000 \\
(0.004)\end{array}$ \\
\hline Negative SKW x credit change & & & & & $\begin{array}{l}-0.008 \\
(0.005)\end{array}$ \\
\hline R-squared & 0.377 & 0.497 & 0.384 & 0.395 & 0.378 \\
\hline Observations & 328 & 328 & 328 & 328 & 328 \\
\hline Number of economies & 82 & 82 & 82 & 82 & 82 \\
\hline
\end{tabular}




\begin{tabular}{|c|c|c|c|c|c|}
\hline \multirow[b]{2}{*}{ Variables } & \multicolumn{5}{|c|}{ OECD } \\
\hline & $\begin{array}{c}\text { (6) } \\
\text { Baseline }\end{array}$ & $\begin{array}{c}\text { (7) } \\
\text { Time } \\
\text { Interactions }\end{array}$ & $\begin{array}{c}\text { (8) } \\
\text { Positive or } \\
\text { Negative SKW }\end{array}$ & $\begin{array}{c}\text { (9) } \\
\text { SKW and Credit } \\
\text { Change }\end{array}$ & $\begin{array}{c}\text { (10) } \\
\text { Positive or } \\
\text { Negative SKW and } \\
\text { Credit Change }\end{array}$ \\
\hline Credit growth (mean) & $\begin{array}{c}0.101^{* *} \\
(0.038)\end{array}$ & $\begin{array}{l}0.213^{* * *} \\
(0.075)\end{array}$ & $\begin{array}{c}0.100^{* *} \\
(0.036)\end{array}$ & $\begin{array}{c}0.046 \\
(0.073)\end{array}$ & $\begin{array}{c}0.056 \\
(0.074)\end{array}$ \\
\hline Credit growth (SD) & $\begin{array}{l}-0.027^{*} \\
(0.015)\end{array}$ & $\begin{array}{l}0.433^{* *} \\
(0.196)\end{array}$ & $\begin{array}{c}-0.028 \\
(0.018)\end{array}$ & $\begin{array}{c}-0.005 \\
(0.024)\end{array}$ & $\begin{array}{l}-0.016 \\
(0.024)\end{array}$ \\
\hline Credit growth (SKW) & $\begin{array}{r}-0.083 \\
(0.107)\end{array}$ & $\begin{array}{c}0.639^{*} \\
(0.363)\end{array}$ & & $\begin{array}{c}0.134 \\
(0.196)\end{array}$ & \\
\hline Credit growth mean x 1971-1980 & & $\begin{array}{l}-0.161^{*} \\
(0.089)\end{array}$ & & & \\
\hline Credit growth mean x 1981-1990 & & $\begin{array}{l}-0.020 \\
(0.095)\end{array}$ & & & \\
\hline Credit growth mean x 1991-2000 & & $\begin{array}{l}-0.130 \\
(0.079)\end{array}$ & & & \\
\hline Credit growth mean x 2001-2010 & & $\begin{array}{c}-0.126 \\
(0.075)\end{array}$ & & & \\
\hline Credit growth SD x 1971-1980 & & $\begin{array}{l}-0.461^{* *} \\
(0.213)\end{array}$ & & & \\
\hline Credit growth SD x 1981-1990 & & $\begin{array}{l}-0.553^{* * *} \\
(0.192)\end{array}$ & & & \\
\hline Credit growth SD x 1991-2000 & & $\begin{array}{l}-0.438^{* *} \\
(0.194)\end{array}$ & & & \\
\hline Credit growth SD x 2001-2010 & & $\begin{array}{l}-0.446^{* *} \\
(0.194)\end{array}$ & & & \\
\hline Credit growth SKW x 1971-1980 & & $\begin{array}{c}-0.488 \\
(0.409)\end{array}$ & & & \\
\hline Credit growth SKW x 1981-1990 & & $\begin{array}{l}-0.772^{* *} \\
(0.367)\end{array}$ & & & \\
\hline Credit growth SKW x 1991-2000 & & $\begin{array}{l}-1.100^{* *} \\
(0.455)\end{array}$ & & & \\
\hline Credit growth SKW x 2001-2010 & & $\begin{array}{c}-0.607 \\
(0.358)\end{array}$ & & & \\
\hline Positive SKW & & & $\begin{array}{r}-0.035 \\
(0.198)\end{array}$ & & $\begin{array}{c}0.175 \\
(0.290)\end{array}$ \\
\hline Negative SKW & & & $\begin{array}{c}-0.138 \\
(0.163)\end{array}$ & & $\begin{array}{c}0.122 \\
(0.296)\end{array}$ \\
\hline SKW $x$ credit change & & & & $\begin{array}{c}-0.005 \\
(0.004)\end{array}$ & \\
\hline Credit change & & & & $\begin{array}{c}0.008 \\
(0.008)\end{array}$ & $\begin{array}{c}0.004 \\
(0.007)\end{array}$ \\
\hline Positive SKW x credit change & & & & & $\begin{array}{c}-0.003 \\
(0.004)\end{array}$ \\
\hline Negative SKW x credit change & & & & & $\begin{array}{c}-0.006 \\
(0.008)\end{array}$ \\
\hline R-squared & 0.613 & 0.710 & 0.613 & 0.623 & 0.617 \\
\hline Observations & 114 & 114 & 114 & 114 & 114 \\
\hline Number of economies & 26 & 26 & 26 & 26 & 26 \\
\hline
\end{tabular}




\begin{tabular}{|c|c|c|c|c|c|}
\hline \multirow[b]{2}{*}{ Variables } & \multicolumn{5}{|c|}{ Developing Economies } \\
\hline & $\begin{array}{c}\text { (11) } \\
\text { Baseline }\end{array}$ & $\begin{array}{c}\text { (12) } \\
\text { Time } \\
\text { Interactions }\end{array}$ & $\begin{array}{c}\text { (13) } \\
\text { Positive or } \\
\text { Negative SKW }\end{array}$ & $\begin{array}{c}\text { (14) } \\
\text { SKW and Credit } \\
\text { Change }\end{array}$ & $\begin{array}{l}\text { (15) } \\
\text { Positive or Negative } \\
\text { SKW and Credit } \\
\text { Change }\end{array}$ \\
\hline Credit growth (mean) & $\begin{array}{l}0.080^{* * *} \\
(0.014)\end{array}$ & $\begin{array}{l}0.162^{* * *} \\
(0.038)\end{array}$ & $\begin{array}{l}0.081^{* * *} \\
(0.015)\end{array}$ & $\begin{array}{l}0.227^{* * *} \\
(0.039)\end{array}$ & $\begin{array}{l}0.197^{* * *} \\
(0.056)\end{array}$ \\
\hline Credit growth (SD) & $\begin{array}{l}-0.049^{* *} \\
(0.022)\end{array}$ & $\begin{array}{l}0.053 \\
(0.063)\end{array}$ & $\begin{array}{l}-0.051^{* *} \\
(0.022)\end{array}$ & $\begin{array}{l}-0.083^{* * *} \\
(0.022)\end{array}$ & $\begin{array}{l}-0.095^{* * *} \\
(0.021)\end{array}$ \\
\hline Credit growth (SKW) & $\begin{array}{c}0.072 \\
(0.180)\end{array}$ & $\begin{array}{c}0.921^{* *} \\
(0.370)\end{array}$ & & $\begin{array}{c}0.164 \\
(0.251)\end{array}$ & \\
\hline Credit growth mean x 1971-1980 & & $\begin{array}{l}-0.186^{* * *} \\
(0.070)\end{array}$ & & & \\
\hline Credit growth mean x 1981-1990 & & $\begin{array}{c}-0.042 \\
(0.077)\end{array}$ & & & \\
\hline Credit growth mean x 1991-2000 & & $\begin{array}{l}-0.138^{* * *} \\
(0.049)\end{array}$ & & & \\
\hline Credit growth mean x 2001-2010 & & $\begin{array}{c}-0.106^{*} \\
(0.063)\end{array}$ & & & \\
\hline Credit growth SD x 1971-1980 & & $\begin{array}{l}-0.023 \\
(0.069)\end{array}$ & & & \\
\hline Credit growth SD x 1981-1990 & & $\begin{array}{l}-0.038 \\
(0.086)\end{array}$ & & & \\
\hline Credit growth SD x 1991-2000 & & $\begin{array}{c}-0.095 \\
(0.062)\end{array}$ & & & \\
\hline Credit growth SD x 2001-2010 & & $\begin{array}{c}-0.005 \\
(0.094)\end{array}$ & & & \\
\hline Credit growth SKW x 1971-1980 & & $\begin{array}{l}-1.364^{* *} \\
(0.609)\end{array}$ & & & \\
\hline Credit growth SKW x 1981-1990 & & $\begin{array}{l}-1.023^{*} \\
(0.549)\end{array}$ & & & \\
\hline Credit growth SKW x 1991-2000 & & $\begin{array}{l}-0.505 \\
(0.469)\end{array}$ & & & \\
\hline Credit growth SKW x 2001-2010 & & $\begin{array}{l}-1.176^{* *} \\
(0.474)\end{array}$ & & & \\
\hline Positive SKW & & & $\begin{array}{c}0.321 \\
(0.308)\end{array}$ & & $\begin{array}{r}0.694 \\
(0.511)\end{array}$ \\
\hline Negative SKW & & & $\begin{array}{c}-0.267 \\
(0.303)\end{array}$ & & $\begin{array}{c}-0.374 \\
(0.287)\end{array}$ \\
\hline SKW $x$ credit change & & & & $\begin{array}{c}-0.001 \\
(0.003)\end{array}$ & \\
\hline Credit change & & & & $\begin{array}{l}-0.019^{* * *} \\
(0.005)\end{array}$ & $\begin{array}{l}-0.016^{* *} \\
(0.007)\end{array}$ \\
\hline Positive SKW x credit change & & & & & $\begin{array}{l}-0.000 \\
(0.004)\end{array}$ \\
\hline Negative SKW x credit change & & & & & $\begin{array}{l}-0.009 \\
(0.005)\end{array}$ \\
\hline R-squared & 0.427 & 0.536 & 0.430 & 0.459 & 0.382 \\
\hline Observations & 214 & 214 & 214 & 214 & 214 \\
\hline Number of economies & 56 & 56 & 56 & 56 & 56 \\
\hline
\end{tabular}

$\mathrm{OECD}=$ Organisation for Economic Co-operation and Development, $\mathrm{SD}=$ standard deviation, $\mathrm{SKW}=$ skewness.

Notes: Standard errors are in parentheses. ${ }^{* *}=p<0.01,{ }^{* *}=p<0.05$, and ${ }^{*}=p<0.1$. Coefficients of the constant, time dummy variables, initial gross domestic product per capita, and initial schooling are not reported here.

Source: Authors' estimates. 
Table 4c: Skewness and Growth of Extended Sample, 1971-2016 (Ordinary Least Squares)

\begin{tabular}{|c|c|c|c|c|c|c|c|c|c|c|c|c|}
\hline \multirow[b]{2}{*}{ Variables } & \multicolumn{4}{|c|}{ Full Sample } & \multicolumn{4}{|c|}{ OECD } & \multicolumn{4}{|c|}{ Developing Economies } \\
\hline & (1) & (2) & (3) & (4) & (5) & (6) & (7) & (8) & (9) & (10) & (11) & (12) \\
\hline Credit growth (mean) & $\begin{array}{l}0.283^{* * *} \\
(0.055)\end{array}$ & $\begin{array}{l}0.279^{* * *} \\
(0.054)\end{array}$ & $\begin{array}{l}0.207^{* * *} \\
(0.063)\end{array}$ & $\begin{array}{l}0.229^{* * *} \\
(0.062)\end{array}$ & $\begin{array}{l}0.439^{* * *} \\
(0.102)\end{array}$ & $\begin{array}{l}0.442^{* * *} \\
(0.106)\end{array}$ & $\begin{array}{c}0.259^{* *} \\
(0.096)\end{array}$ & $\begin{array}{l}0.312^{* *} \\
(0.120)\end{array}$ & $\begin{array}{l}0.263^{* * *} \\
(0.055)\end{array}$ & $\begin{array}{l}0.259^{* * *} \\
(0.053)\end{array}$ & $\begin{array}{c}0.214^{* *} \\
(0.084)\end{array}$ & $\begin{array}{c}0.172^{*} \\
(0.098)\end{array}$ \\
\hline Credit growth (SD) & $\begin{array}{l}-0.105^{* * *} \\
(0.024)\end{array}$ & $\begin{array}{l}-0.103^{* * *} \\
(0.025)\end{array}$ & $\begin{array}{l}-0.087^{* * *} \\
(0.022)\end{array}$ & $\begin{array}{l}-0.091^{* * *} \\
(0.022)\end{array}$ & $\begin{array}{l}-0.071^{* * *} \\
(0.018)\end{array}$ & $\begin{array}{l}-0.082^{* * *} \\
(0.022)\end{array}$ & $\begin{array}{l}-0.048^{* *} \\
(0.017)\end{array}$ & $\begin{array}{l}-0.074^{* *} \\
(0.030)\end{array}$ & $\begin{array}{l}-0.110^{* * *} \\
(0.023)\end{array}$ & $\begin{array}{l}-0.102^{* * *} \\
(0.022)\end{array}$ & $\begin{array}{l}-0.078^{* * *} \\
(0.024)\end{array}$ & $\begin{array}{l}-0.085^{* * *} \\
(0.026)\end{array}$ \\
\hline Credit growth (SKW) & $\begin{array}{l}-0.178^{* *} \\
(0.077)\end{array}$ & & $\begin{array}{l}-0.082 \\
(0.077)\end{array}$ & & $\begin{array}{l}-0.231^{* * *} \\
(0.063)\end{array}$ & & $\begin{array}{l}-0.161^{* * *} \\
(0.049)\end{array}$ & & $\begin{array}{l}-0.379^{* *} \\
(0.170)\end{array}$ & & $\begin{array}{c}0.430 \\
(0.294)\end{array}$ & \\
\hline Positive SKW & & $\begin{array}{l}-0.208^{*} \\
(0.112)\end{array}$ & & $\begin{array}{r}-0.079 \\
(0.119)\end{array}$ & & $\begin{array}{l}-0.165 \\
(0.096)\end{array}$ & & $\begin{array}{l}-0.051 \\
(0.105)\end{array}$ & & $\begin{array}{l}-0.767^{* * *} \\
(0.248)\end{array}$ & & $\begin{array}{l}-0.421 \\
(0.367)\end{array}$ \\
\hline Negative SKW & & $\begin{array}{l}-0.062 \\
(0.190)\end{array}$ & & $\begin{array}{l}-0.051 \\
(0.195)\end{array}$ & & $\begin{array}{l}-0.436^{* * *} \\
(0.141)\end{array}$ & & $\begin{array}{c}-0.332^{*} \\
(0.169)\end{array}$ & & $\begin{array}{c}0.447 \\
(0.357)\end{array}$ & & $\begin{array}{c}0.207 \\
(0.379)\end{array}$ \\
\hline SKW $x$ credit change & & & $\begin{array}{l}-0.001^{* *} \\
(0.000)\end{array}$ & & & & $\begin{array}{l}-0.000 \\
(0.000)\end{array}$ & & & & $\begin{array}{l}-0.004^{* *} \\
(0.001)\end{array}$ & \\
\hline Credit change & & & $\begin{array}{l}0.003^{* * *} \\
(0.001)\end{array}$ & $\begin{array}{l}0.002^{* * *} \\
(0.001)\end{array}$ & & & $\begin{array}{l}0.002^{* * *} \\
(0.001)\end{array}$ & $\begin{array}{l}0.002^{* *} \\
(0.001)\end{array}$ & & & $\begin{array}{c}0.004 \\
(0.003)\end{array}$ & $\begin{array}{c}0.004 \\
(0.003)\end{array}$ \\
\hline $\begin{array}{l}\text { Positive SKW } \\
\quad x \text { credit change }\end{array}$ & & & & $\begin{array}{l}-0.004^{*} \\
(0.002)\end{array}$ & & & & $\begin{array}{l}-0.003^{* *} \\
(0.001)\end{array}$ & & & & $\begin{array}{l}-0.003 \\
(0.004)\end{array}$ \\
\hline $\begin{array}{l}\text { Negative SKW } \\
x \text { credit change }\end{array}$ & & & & $\begin{array}{l}-0.004 \\
(0.010)\end{array}$ & & & & $\begin{array}{l}-0.002 \\
(0.010)\end{array}$ & & & & $\begin{array}{l}-0.004 \\
(0.011)\end{array}$ \\
\hline Constant & $\begin{array}{l}4.695^{* * *} \\
(1.538)\end{array}$ & $\begin{array}{l}4.546^{* * *} \\
(1.651)\end{array}$ & $\begin{array}{l}3.399^{* *} \\
(1.431)\end{array}$ & $\begin{array}{l}3.642^{* *} \\
(1.474)\end{array}$ & $\begin{array}{c}0.637 \\
(2.664)\end{array}$ & $\begin{array}{r}1.763 \\
(2.731)\end{array}$ & $\begin{array}{l}3.225 \\
(2.566)\end{array}$ & $\begin{array}{c}3.966 \\
(2.967)\end{array}$ & $\begin{array}{c}2.203 \\
(2.068)\end{array}$ & $\begin{array}{c}1.672 \\
(1.970)\end{array}$ & $\begin{array}{c}1.182 \\
(2.189)\end{array}$ & $\begin{array}{c}1.262 \\
(1.975)\end{array}$ \\
\hline Observations & 82 & 82 & 82 & 82 & 26 & 26 & 26 & 26 & 56 & 56 & 56 & 56 \\
\hline Adjusted R-squared & 0.483 & 0.477 & 0.530 & 0.534 & 0.706 & 0.701 & 0.773 & 0.790 & 0.430 & 0.462 & 0.497 & 0.456 \\
\hline
\end{tabular}

OECD = Organisation for Economic Co-operation and Development, $S D=$ standard deviation, $S K W=$ skewness.

Notes: Standard errors are in parentheses. ${ }^{* *}=p<0.01,{ }^{* *}=p<0.05$, and ${ }^{*}=p<0.1$. Coefficients of initial gross domestic product per capita and initial schooling are not reported here. Source: Authors' estimates. 


\section{Extensions of the Ranciere, Tornell, and Westermann (2008) Sample}

In this section, we go back to the RTW sample and examine whether the impact of skewness has a different effect by decade and whether nonlinearities are present in a smaller sample. In Table 5a, we find a different effect for the full sample and developing economy estimations in the RTW sample for the period 1971-2000. For the full sample, negative skewness was associated with higher growth in the 1990s relative to the base period. For developing economies, lower skewness appears to have lifted growth in the 1980s; in the 1990s, it was positive skewness that mattered for growth. Accounting for differential effects of positive and negative skewness, columns (3) and (5) in Table 5a confirm the direct association between negative skewness and growth for the full sample. Moreover, columns (3) and (8) show that positive skewness is negatively linked with growth for the full sample and advanced economy subsample, respectively.

Applying fixed effects to the RTW sample for 1971-2000, Table 5b shows that that negative skewness is linked to higher growth, as seen in columns (3) and (5) for the full sample, column (8) for the OECD subsample, and columns (13) and (15) for the developing economy subsample. At the same time, positive skewness may be associated with stronger growth in both the advanced economy subsample (column [10]) and developing economy subsample (column [15]).

In Table 6a, where we extended the time period of the RTW sample to cover 1971-2016, we find that negative skewness was only directly linked to growth in the 1970s and 1980s but not in the decades after 1990, as evident in the full sample and developing economy subsample (columns [2] and [12]). In the OECD subsample, we did not find any significant coefficients for negative skewness. Results for the fixed effects in Table $6 \mathrm{~b}$ depict a similar picture. Skewness is negative and significant for some decades for the full sample and developing economy subsample, but observed only in the 1990s for the OECD subsample. The fixed effects estimations also show that positive skewness is positive and significant for the full sample (columns [3] and [5]) and for the developing economy subsample (column [15]). 
Table 5a: Skewness and Growth-Ranciere, Tornell, and Westermann (2008) Sample, 1971-2000 (Panel Generalized Least Squares)

\begin{tabular}{|c|c|c|c|c|c|}
\hline & \multicolumn{5}{|c|}{ Full sample } \\
\hline & $\begin{array}{c}\text { (1) } \\
\text { Baseline }\end{array}$ & $\begin{array}{c}\text { (2) } \\
\text { Time } \\
\text { Interactions }\end{array}$ & $\begin{array}{c}\text { (3) } \\
\text { Positive or Negative } \\
\text { SKW }\end{array}$ & $\begin{array}{l}\text { (4) } \\
\text { SKW and } \\
\text { Credit Change }\end{array}$ & $\begin{array}{c}\text { (5) } \\
\text { Positive or Negative } \\
\text { SKW and Credit Change }\end{array}$ \\
\hline Credit growth (mean) & $\begin{array}{l}0.160^{* * *} \\
(0.019)\end{array}$ & $\begin{array}{l}0.169^{* * *} \\
(0.041)\end{array}$ & $\begin{array}{l}0.160^{* * *} \\
(0.019)\end{array}$ & $\begin{array}{l}0.241^{* * *} \\
(0.057)\end{array}$ & $\begin{array}{l}0.225^{* * *} \\
(0.059)\end{array}$ \\
\hline Credit growth (SD) & $\begin{array}{l}-0.033^{* * *} \\
(0.009)\end{array}$ & $\begin{array}{l}-0.041^{*} \\
(0.021)\end{array}$ & $\begin{array}{l}-0.033^{* * *} \\
(0.009)\end{array}$ & $\begin{array}{l}-0.029^{* *} \\
(0.013)\end{array}$ & $\begin{array}{l}-0.020 \\
(0.013)\end{array}$ \\
\hline Credit growth (SKW) & $\begin{array}{l}-0.439^{* * *} \\
(0.114)\end{array}$ & $\begin{array}{l}-0.884^{* * *} \\
(0.235)\end{array}$ & & $\begin{array}{l}-0.145 \\
(0.149)\end{array}$ & \\
\hline Credit growth mean x 1981-1990 & & $\begin{array}{c}0.020 \\
(0.049)\end{array}$ & & & \\
\hline Credit growth mean x 1991-2000 & & $\begin{array}{l}-0.029 \\
(0.050)\end{array}$ & & & \\
\hline Credit growth SD x 1981-1990 & & $\begin{array}{l}-0.032 \\
(0.027)\end{array}$ & & & \\
\hline Credit growth SD x 1991-2000 & & $\begin{array}{c}0.007 \\
(0.024)\end{array}$ & & & \\
\hline Credit growth SKW x 1981-1990 & & $\begin{array}{c}0.433 \\
(0.304)\end{array}$ & & & \\
\hline Credit growth SKW x 1991-2000 & & $\begin{array}{l}0.815^{* * *} \\
(0.290)\end{array}$ & & & \\
\hline Positive SKW & & & $\begin{array}{l}-0.427^{* *} \\
(0.185)\end{array}$ & & $\begin{array}{c}0.288 \\
(0.295)\end{array}$ \\
\hline Negative SKW & & & $\begin{array}{l}-0.456^{*} \\
(0.244)\end{array}$ & & $\begin{array}{l}-0.764^{* * *} \\
(0.294)\end{array}$ \\
\hline SKW $x$ credit change & & & & $\begin{array}{l}-0.006^{* * *} \\
(0.002)\end{array}$ & \\
\hline Credit change & & & & $\begin{array}{l}-0.007 \\
(0.006)\end{array}$ & $\begin{array}{c}0.001 \\
(0.007)\end{array}$ \\
\hline Positive SKW x credit change & & & & & $\begin{array}{l}-0.012^{* * *} \\
(0.003)\end{array}$ \\
\hline Negative SKW x credit change & & & & & $\begin{array}{c}0.008 \\
(0.007)\end{array}$ \\
\hline Observations & 120 & 120 & 120 & 120 & 120 \\
\hline Number of economies & 44 & 44 & 44 & 44 & 44 \\
\hline
\end{tabular}




\begin{tabular}{|c|c|c|c|c|c|c|c|c|c|c|}
\hline & \multicolumn{5}{|c|}{ OECD } & \multicolumn{5}{|c|}{ Developing Economies } \\
\hline & (6) & $\begin{array}{c}\text { (7) } \\
\text { Time } \\
\text { Interactions } \\
\end{array}$ & $\begin{array}{l}\text { (8) } \\
\text { Positive or } \\
\text { Negative } \\
\text { SKW }\end{array}$ & $\begin{array}{c}\text { (9) } \\
\text { SKW and } \\
\text { Credit } \\
\text { Change }\end{array}$ & $\begin{array}{c}\text { (10) } \\
\text { Positive or } \\
\text { Negative SKW } \\
\text { and Credit } \\
\text { Change }\end{array}$ & (11) & $\begin{array}{c}\text { (12) } \\
\text { Time } \\
\text { Interactions }\end{array}$ & $\begin{array}{l}\text { (13) } \\
\text { Positive or } \\
\text { Negative } \\
\text { SKW }\end{array}$ & $\begin{array}{c}\text { (14) } \\
\text { SKW and } \\
\text { Credit } \\
\text { Change }\end{array}$ & $\begin{array}{c}\text { (15) } \\
\text { Positive or } \\
\text { Negative SKW } \\
\text { and Credit } \\
\text { Change }\end{array}$ \\
\hline Credit growth (mean) & $\begin{array}{l}0.199^{* * *} \\
(0.038)\end{array}$ & $\begin{array}{l}0.140^{* *} \\
(0.065)\end{array}$ & $\begin{array}{l}0.212^{* * *} \\
(0.038)\end{array}$ & $\begin{array}{r}0.041 \\
(0.118)\end{array}$ & $\begin{array}{r}0.053 \\
(0.122)\end{array}$ & $\begin{array}{l}0.141^{* * *} \\
(0.027)\end{array}$ & $\begin{array}{l}0.259^{* * *} \\
(0.060)\end{array}$ & $\begin{array}{l}0.142^{* * *} \\
(0.027)\end{array}$ & $\begin{array}{l}0.351^{* * *} \\
(0.090)\end{array}$ & $\begin{array}{l}0.310^{* * *} \\
(0.097)\end{array}$ \\
\hline Credit growth (SD) & $\begin{array}{l}-0.039^{* * *} \\
(0.014)\end{array}$ & $\begin{array}{c}0.010 \\
(0.060)\end{array}$ & $\begin{array}{l}-0.040^{* * *} \\
(0.014)\end{array}$ & $\begin{array}{c}0.010 \\
(0.025)\end{array}$ & $\begin{array}{c}0.009 \\
(0.025)\end{array}$ & $\begin{array}{l}-0.055^{* *} \\
(0.021)\end{array}$ & $\begin{array}{l}-0.062^{*} \\
(0.033)\end{array}$ & $\begin{array}{l}-0.059^{* * *} \\
(0.022)\end{array}$ & $\begin{array}{l}-0.068^{* *} \\
(0.029)\end{array}$ & $\begin{array}{l}-0.055^{*} \\
(0.029)\end{array}$ \\
\hline Credit growth (SKW) & $\begin{array}{l}-0.491^{* * *} \\
(0.164)\end{array}$ & $\begin{array}{l}-0.302 \\
(0.415)\end{array}$ & & $\begin{array}{c}0.206 \\
(0.276)\end{array}$ & & $\begin{array}{l}-0.329 \\
(0.202)\end{array}$ & $\begin{array}{l}-1.759^{* * *} \\
(0.421)\end{array}$ & & $\begin{array}{l}-0.025 \\
(0.218)\end{array}$ & \\
\hline Credit growth mean x 1981-1990 & & $\begin{array}{c}0.137 \\
(0.101)\end{array}$ & & & & & $\begin{array}{l}-0.064 \\
(0.076)\end{array}$ & & & \\
\hline Credit growth mean x 1991-2000 & & $\begin{array}{c}0.069 \\
(0.087)\end{array}$ & & & & & $\begin{array}{l}-0.120^{*} \\
(0.071)\end{array}$ & & & \\
\hline Credit growth SD x 1981-1990 & & $\begin{array}{l}-0.123^{*} \\
(0.066)\end{array}$ & & & & & $\begin{array}{c}0.066 \\
(0.062)\end{array}$ & & & \\
\hline Credit growth SD x 1991-2000 & & $\begin{array}{l}-0.045 \\
(0.063)\end{array}$ & & & & & $\begin{array}{r}0.040 \\
(0.051)\end{array}$ & & & \\
\hline Credit growth SKW x 1981-1990 & & $\begin{array}{l}-0.083 \\
(0.532)\end{array}$ & & & & & $\begin{array}{l}1.588^{* * *} \\
(0.571)\end{array}$ & & & \\
\hline Credit growth SKW x 1991-2000 & & $\begin{array}{l}-0.391 \\
(0.521)\end{array}$ & & & & & $\begin{array}{l}1.922^{* * *} \\
(0.511)\end{array}$ & & & \\
\hline Positive SKW & & & $\begin{array}{l}-0.656^{* * *} \\
(0.253)\end{array}$ & & $\begin{array}{c}0.254 \\
(0.457)\end{array}$ & & & $\begin{array}{c}-0.203 \\
(0.348)\end{array}$ & & $\begin{array}{r}0.584 \\
(0.571)\end{array}$ \\
\hline Negative SKW & & & $\begin{array}{l}-0.101 \\
(0.452)\end{array}$ & & $\begin{array}{c}0.039 \\
(0.730)\end{array}$ & & & $\begin{array}{l}-0.514 \\
(0.367)\end{array}$ & & $\begin{array}{c}-0.619 \\
(0.398)\end{array}$ \\
\hline SKW $x$ credit change & & & & $\begin{array}{l}-0.013^{* * *} \\
(0.004)\end{array}$ & & & & & $\begin{array}{c}-0.004 \\
(0.003)\end{array}$ & \\
\hline Credit change & & & & $\begin{array}{c}0.023^{*} \\
(0.013)\end{array}$ & $\begin{array}{c}0.022^{*} \\
(0.013)\end{array}$ & & & & $\begin{array}{l}-0.024^{* *} \\
(0.010)\end{array}$ & $\begin{array}{l}-0.013 \\
(0.012)\end{array}$ \\
\hline Positive SKW x credit change & & & & & $\begin{array}{l}-0.013^{* *} \\
(0.006)\end{array}$ & & & & & $\begin{array}{c}-0.012^{*} \\
(0.006)\end{array}$ \\
\hline Negative SKW x credit change & & & & & $\begin{array}{l}-0.008 \\
(0.020)\end{array}$ & & & & & $\begin{array}{c}0.008 \\
(0.008)\end{array}$ \\
\hline Observations & 58 & 58 & 58 & 58 & 58 & 62 & 62 & 62 & 62 & 62 \\
\hline Number of economies & 21 & 21 & 21 & 21 & 21 & 23 & 23 & 23 & 23 & 23 \\
\hline
\end{tabular}

OECD = Organisation for Economic Co-operation and Development, $\mathrm{SD}=$ standard deviation, $\mathrm{SKW}=$ skewness.

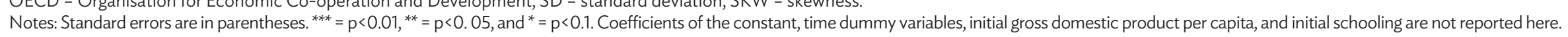
Source: Authors' estimates. 
Table 5b: Skewness and Growth of Ranciere, Tornell, and Westermann (2008) Sample, 1971-2000 (Fixed Effects)

\begin{tabular}{|c|c|c|c|c|c|}
\hline & \multicolumn{5}{|c|}{ Full Sample } \\
\hline & $\begin{array}{l}\text { (1) } \\
\text { Baseline }\end{array}$ & $\begin{array}{c}\text { (2) } \\
\text { Time } \\
\text { Interactions }\end{array}$ & $\begin{array}{c}\text { (3) } \\
\text { Positive or Negative } \\
\text { SKW }\end{array}$ & $\begin{array}{c}\text { (4) } \\
\text { SKW and } \\
\text { Credit Change }\end{array}$ & $\begin{array}{c}\text { (5) } \\
\text { Positive or Negative } \\
\text { SKW and Credit Change }\end{array}$ \\
\hline Credit growth (mean) & $\begin{array}{c}0.071^{* *} \\
(0.027)\end{array}$ & $\begin{array}{c}-0.090 \\
(0.063)\end{array}$ & $\begin{array}{l}0.074^{* * *} \\
(0.025)\end{array}$ & $\begin{array}{c}0.014 \\
(0.092)\end{array}$ & $\begin{array}{c}0.029 \\
(0.079)\end{array}$ \\
\hline Credit growth (SD) & $\begin{array}{l}-0.022^{* *} \\
(0.011)\end{array}$ & $\begin{array}{c}0.044 \\
(0.032)\end{array}$ & $\begin{array}{l}-0.040^{* * *} \\
(0.011)\end{array}$ & $\begin{array}{l}-0.015 \\
(0.020)\end{array}$ & $\begin{array}{l}-0.028 \\
(0.018)\end{array}$ \\
\hline Credit growth (SKW) & $\begin{array}{l}-0.028 \\
(0.151)\end{array}$ & $\begin{array}{l}0.018 \\
(0.240)\end{array}$ & & $\begin{array}{l}-0.071 \\
(0.225)\end{array}$ & \\
\hline Credit growth mean x 1981-1990 & & $\begin{array}{l}0.186^{* * *} \\
(0.068)\end{array}$ & & & \\
\hline Credit growth mean x 1991-2000 & & $\begin{array}{l}0.162^{* *} \\
(0.078)\end{array}$ & & & \\
\hline Credit growth SD x 1981-1990 & & $\begin{array}{l}-0.104^{* * *} \\
(0.037)\end{array}$ & & & \\
\hline Credit growth SD x 1991-2000 & & $\begin{array}{l}-0.058^{*} \\
(0.034)\end{array}$ & & & \\
\hline Credit growth SKW x 1981-1990 & & $\begin{array}{c}0.098 \\
(0.365)\end{array}$ & & & \\
\hline Credit growth SKW x 1991-2000 & & $\begin{array}{l}-0.118 \\
(0.423)\end{array}$ & & & \\
\hline Positive SKW & & & $\begin{array}{l}0.573^{* * *} \\
(0.210)\end{array}$ & & $\begin{array}{l}0.764^{* *} \\
(0.356)\end{array}$ \\
\hline Negative SKW & & & $\begin{array}{l}-0.851^{* * *} \\
(0.215)\end{array}$ & & $\begin{array}{l}-0.825^{* * *} \\
(0.239)\end{array}$ \\
\hline SKW $x$ credit change & & & & $\begin{array}{c}0.001 \\
(0.003)\end{array}$ & \\
\hline Credit change & & & & $\begin{array}{c}0.007 \\
(0.009)\end{array}$ & $\begin{array}{c}0.006 \\
(0.008)\end{array}$ \\
\hline Positive SKW x credit change & & & & & $\begin{array}{l}-0.003 \\
(0.004)\end{array}$ \\
\hline Negative SKW x credit change & & & & & $\begin{array}{c}-0.004 \\
(0.005)\end{array}$ \\
\hline R-squared & 0.522 & 0.596 & 0.564 & 0.525 & 0.570 \\
\hline Observations & 120 & 120 & 120 & 120 & 120 \\
\hline Number of economies & 44 & 44 & 44 & 44 & 44 \\
\hline
\end{tabular}




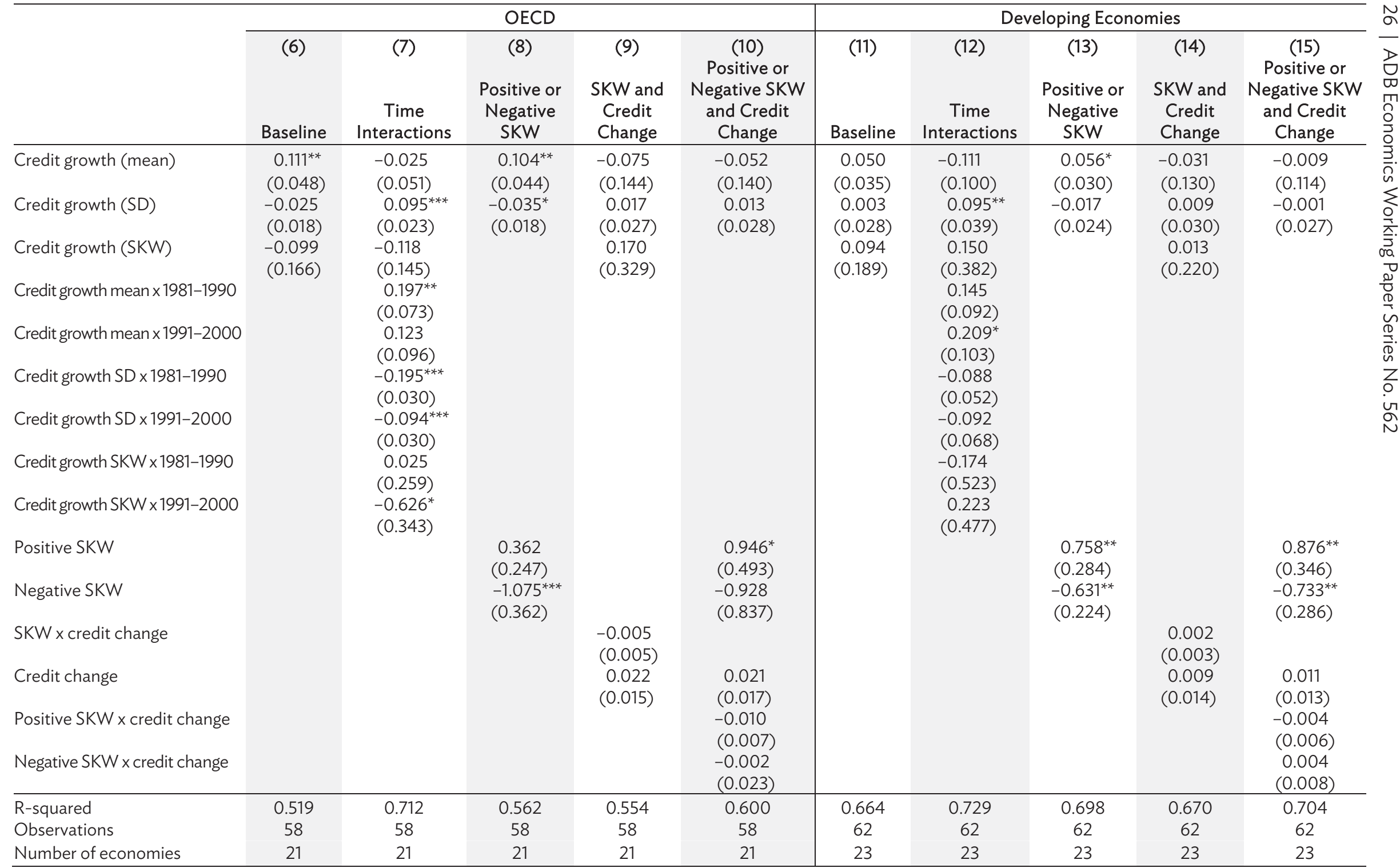

OECD = Organisation for Economic Co-operation and Development, $\mathrm{SD}=$ standard deviation, $\mathrm{SKW}=$ skewness.

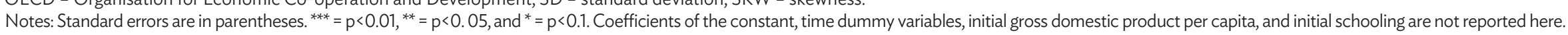
Source: Authors' estimates. 


\section{Table 6a: Skewness and Growth of Ranciere, Tornell, and Westermann (2008) Sample, 1971-2016 (Panel Generalized Least Squares)}

\begin{tabular}{|c|c|c|c|c|c|}
\hline \multirow[b]{2}{*}{ Variables } & \multicolumn{5}{|c|}{ Full Sample } \\
\hline & $\begin{array}{c}\text { (1) } \\
\text { Baseline }\end{array}$ & $\begin{array}{c}\text { (2) } \\
\text { Time } \\
\text { Interactions }\end{array}$ & $\begin{array}{c}\text { (3) } \\
\text { Positive or } \\
\text { Negative SKW }\end{array}$ & $\begin{array}{c}\text { (4) } \\
\text { SKW and } \\
\text { Credit Change }\end{array}$ & $\begin{array}{c}\text { (5) } \\
\text { Positive or } \\
\text { Negative SKW and } \\
\text { Credit Change }\end{array}$ \\
\hline Credit growth (mean) & $\begin{array}{l}0.161^{* * *} \\
(0.015)\end{array}$ & $\begin{array}{l}0.165^{* * *} \\
(0.029)\end{array}$ & $\begin{array}{l}0.161^{* * *} \\
(0.015)\end{array}$ & $\begin{array}{l}0.250^{* * *} \\
(0.037)\end{array}$ & $\begin{array}{l}0.235^{* * *} \\
(0.037)\end{array}$ \\
\hline Credit growth (SD) & $\begin{array}{l}-0.039^{* * *} \\
(0.008)\end{array}$ & $\begin{array}{l}0.200^{* * *} \\
(0.065)\end{array}$ & $\begin{array}{l}-0.037^{* * *} \\
(0.009)\end{array}$ & $\begin{array}{l}-0.039^{* * *} \\
(0.010)\end{array}$ & $\begin{array}{l}-0.027^{* *} \\
(0.011)\end{array}$ \\
\hline Credit growth (SKW) & $\begin{array}{l}-0.175^{* *} \\
(0.086)\end{array}$ & $\begin{array}{r}0.484 \\
(0.321)\end{array}$ & & $\begin{array}{l}-0.096 \\
(0.116)\end{array}$ & \\
\hline Credit growth mean x 1971-1980 & & $\begin{array}{l}-0.002 \\
(0.051)\end{array}$ & & & \\
\hline Credit growth mean x 1981-1990 & & $\begin{array}{c}0.010 \\
(0.041)\end{array}$ & & & \\
\hline Credit growth mean x 1991-2000 & & $\begin{array}{c}-0.008 \\
(0.045)\end{array}$ & & & \\
\hline Credit growth mean x 2001-2010 & & $\begin{array}{l}-0.118^{* * *} \\
(0.042)\end{array}$ & & & \\
\hline Credit growth SD x 1971-1980 & & $\begin{array}{l}-0.246^{* * *} \\
(0.068)\end{array}$ & & & \\
\hline Credit growth SD x 1981-1990 & & $\begin{array}{l}-0.272^{* * *} \\
(0.066)\end{array}$ & & & \\
\hline Credit growth SD x 1991-2000 & & $\begin{array}{l}-0.240^{* * *} \\
(0.066)\end{array}$ & & & \\
\hline Credit growth SD x 2001-2010 & & $\begin{array}{l}-0.186^{* * *} \\
(0.068)\end{array}$ & & & \\
\hline Credit growth SKW x 1971-1980 & & $\begin{array}{l}-1.215^{\text {***}} \\
(0.411)\end{array}$ & & & \\
\hline Credit growth SKW x 1981-1990 & & $\begin{array}{l}-0.863^{* *} \\
(0.390)\end{array}$ & & & \\
\hline Credit growth SKW x 1991-2000 & & $\begin{array}{l}-0.614 \\
(0.382)\end{array}$ & & & \\
\hline Credit growth SKW x 2001-2010 & & $\begin{array}{l}-0.544 \\
(0.361)\end{array}$ & & & \\
\hline Positive SKW & & & $\begin{array}{l}-0.214 \\
(0.142)\end{array}$ & & $\begin{array}{c}0.018 \\
(0.195)\end{array}$ \\
\hline Negative SKW & & & $\begin{array}{l}-0.128 \\
(0.199)\end{array}$ & & $\begin{array}{l}-0.298 \\
(0.219)\end{array}$ \\
\hline SKW $x$ credit change & & & & $\begin{array}{l}-0.004^{* *} \\
(0.002)\end{array}$ & \\
\hline Credit change & & & & $\begin{array}{l}-0.011^{* * *} \\
(0.004)\end{array}$ & $\begin{array}{l}-0.003 \\
(0.005)\end{array}$ \\
\hline Positive SKW x credit change & & & & & $\begin{array}{l}-0.009^{* * *} \\
(0.002)\end{array}$ \\
\hline Negative SKW x credit change & & & & & $\begin{array}{r}0.008^{*} \\
(0.004) \\
\end{array}$ \\
\hline Observations & 197 & 197 & 197 & 197 & 197 \\
\hline Number of economies & 44 & 44 & 44 & 44 & 44 \\
\hline
\end{tabular}


Table 6a continued

\begin{tabular}{|c|c|c|c|c|c|}
\hline \multirow[b]{2}{*}{ Variables } & \multicolumn{5}{|c|}{ OECD } \\
\hline & $\begin{array}{c}\text { (6) } \\
\text { Baseline }\end{array}$ & $\begin{array}{c}\text { (7) } \\
\text { Time } \\
\text { Interactions }\end{array}$ & $\begin{array}{c}\text { (8) } \\
\text { Positive or } \\
\text { Negative SKW }\end{array}$ & $\begin{array}{c}\text { (9) } \\
\text { SKW and } \\
\text { Credit Change }\end{array}$ & $\begin{array}{c}\text { (10) } \\
\text { Positive or } \\
\text { Negative SKW and } \\
\text { Credit Change }\end{array}$ \\
\hline Credit growth (mean) & $\begin{array}{l}0.135^{* * *} \\
(0.025)\end{array}$ & $\begin{array}{l}0.193^{* * *} \\
(0.062)\end{array}$ & $\begin{array}{l}0.137^{* * *} \\
(0.026)\end{array}$ & $\begin{array}{c}0.050 \\
(0.062)\end{array}$ & $\begin{array}{c}0.062 \\
(0.063)\end{array}$ \\
\hline Credit growth (SD) & $\begin{array}{l}-0.029^{* * *} \\
(0.011)\end{array}$ & $\begin{array}{l}0.467^{* * *} \\
(0.164)\end{array}$ & $\begin{array}{l}-0.028^{* *} \\
(0.011)\end{array}$ & $\begin{array}{r}0.005 \\
(0.018)\end{array}$ & $\begin{array}{r}0.002 \\
(0.019)\end{array}$ \\
\hline Credit growth (SKW) & $\begin{array}{l}-0.138 \\
(0.105)\end{array}$ & $\begin{array}{c}0.105 \\
(0.468)\end{array}$ & & $\begin{array}{r}0.220 \\
(0.179)\end{array}$ & \\
\hline Credit growth mean x 1971-1980 & & $\begin{array}{l}-0.075 \\
(0.091)\end{array}$ & & & \\
\hline Credit growth mean x 1981-1990 & & $\begin{array}{l}-0.025 \\
(0.105)\end{array}$ & & & \\
\hline Credit growth mean x 1991-2000 & & $\begin{array}{c}0.002 \\
(0.079)\end{array}$ & & & \\
\hline Credit growth mean x 2001-2010 & & $\begin{array}{l}-0.120 \\
(0.084)\end{array}$ & & & \\
\hline Credit growth SD x 1971-1980 & & $\begin{array}{l}-0.436^{* *} \\
(0.184)\end{array}$ & & & \\
\hline Credit growth SD x 1981-1990 & & $\begin{array}{l}-0.545^{* * *} \\
(0.168)\end{array}$ & & & \\
\hline Credit growth SD x 1991-2000 & & $\begin{array}{l}-0.499^{* * *} \\
(0.166)\end{array}$ & & & \\
\hline Credit growth SD x 2001-2010 & & $\begin{array}{l}-0.471^{* * *} \\
(0.167)\end{array}$ & & & \\
\hline Credit growth SKW x 1971-1980 & & $\begin{array}{r}-0.506 \\
(0.631)\end{array}$ & & & \\
\hline Credit growth SKW x 1981-1990 & & $\begin{array}{l}-0.496 \\
(0.564)\end{array}$ & & & \\
\hline Credit growth SKW x 1991-2000 & & $\begin{array}{l}-0.839 \\
(0.564)\end{array}$ & & & \\
\hline Credit growth SKW x 2001-2010 & & $\begin{array}{l}-0.080 \\
(0.504)\end{array}$ & & & \\
\hline Positive SKW & & & $\begin{array}{l}-0.249 \\
(0.171)\end{array}$ & & $\begin{array}{c}0.306 \\
(0.228)\end{array}$ \\
\hline Negative SKW & & & $\begin{array}{l}-0.093 \\
(0.265)\end{array}$ & & $\begin{array}{r}0.070 \\
(0.341)\end{array}$ \\
\hline SKW $x$ credit change & & & & $\begin{array}{l}-0.008^{* * *} \\
(0.003)\end{array}$ & \\
\hline Credit change & & & & $\begin{array}{c}0.011 \\
(0.008)\end{array}$ & $\begin{array}{l}0.020^{* *} \\
(0.008)\end{array}$ \\
\hline Positive SKW x credit change & & & & & $\begin{array}{l}-0.013^{* * *} \\
(0.003)\end{array}$ \\
\hline Negative SKW x credit change & & & & & $\begin{array}{c}0.003 \\
(0.010)\end{array}$ \\
\hline Observations & 98 & 98 & 98 & 98 & 98 \\
\hline Number of economies & 21 & 21 & 21 & 21 & 21 \\
\hline
\end{tabular}




\begin{tabular}{|c|c|c|c|c|c|}
\hline \multirow[b]{2}{*}{ Variables } & \multicolumn{5}{|c|}{ Developing Economies } \\
\hline & $\begin{array}{c}\text { (11) } \\
\text { Baseline }\end{array}$ & $\begin{array}{c}\text { (12) } \\
\text { Time } \\
\text { Interactions }\end{array}$ & $\begin{array}{c}\text { (13) } \\
\text { Positive or } \\
\text { Negative SKW }\end{array}$ & $\begin{array}{c}\text { (14) } \\
\text { SKW and } \\
\text { Credit Change }\end{array}$ & $\begin{array}{c}\text { (15) } \\
\text { Positive or } \\
\text { Negative SKW and } \\
\text { Credit Change }\end{array}$ \\
\hline Credit growth (mean) & $\begin{array}{l}0.101^{* * *} \\
(0.019)\end{array}$ & $\begin{array}{l}0.137^{* * *} \\
(0.044)\end{array}$ & $\begin{array}{l}0.101^{* * *} \\
(0.020)\end{array}$ & $\begin{array}{l}0.370^{* * *} \\
(0.064)\end{array}$ & $\begin{array}{l}0.247^{* * *} \\
(0.055)\end{array}$ \\
\hline Credit growth (SD) & $\begin{array}{l}-0.055^{* * *} \\
(0.019)\end{array}$ & $\begin{array}{c}0.146^{* *} \\
(0.070)\end{array}$ & $\begin{array}{l}-0.058^{* * *} \\
(0.021)\end{array}$ & $\begin{array}{l}-0.077^{* * *} \\
(0.020)\end{array}$ & $\begin{array}{l}-0.035^{*} \\
(0.020)\end{array}$ \\
\hline Credit growth (SKW) & $\begin{array}{l}-0.158 \\
(0.163)\end{array}$ & $\begin{array}{c}0.879 \\
(0.543)\end{array}$ & & $\begin{array}{r}0.089 \\
(0.179)\end{array}$ & \\
\hline Credit growth mean x 1971-1980 & & $\begin{array}{c}0.110 \\
(0.070)\end{array}$ & & & \\
\hline Credit growth mean x 1981-1990 & & $\begin{array}{c}0.054 \\
(0.056)\end{array}$ & & & \\
\hline Credit growth mean x 1991-2000 & & $\begin{array}{l}-0.011 \\
(0.054)\end{array}$ & & & \\
\hline Credit growth mean x 2001-2010 & & $\begin{array}{c}-0.068 \\
(0.067)\end{array}$ & & & \\
\hline Credit growth SD x 1971-1980 & & $\begin{array}{l}-0.206^{* * *} \\
(0.078)\end{array}$ & & & \\
\hline Credit growth SD x 1981-1990 & & $\begin{array}{l}-0.124 \\
(0.089)\end{array}$ & & & \\
\hline Credit growth SD x 1991-2000 & & $\begin{array}{c}-0.143^{*} \\
(0.081)\end{array}$ & & & \\
\hline Credit growth SD x 2001-2010 & & $\begin{array}{l}-0.217^{* * *} \\
(0.084)\end{array}$ & & & \\
\hline Credit growth SKW x 1971-1980 & & $\begin{array}{l}-2.666^{* * *} \\
(0.721)\end{array}$ & & & \\
\hline Credit growth SKW x 1981-1990 & & $\begin{array}{l}-1.179^{*} \\
(0.626)\end{array}$ & & & \\
\hline Credit growth SKW x 1991-2000 & & $\begin{array}{l}-0.761 \\
(0.615)\end{array}$ & & & \\
\hline Credit growth SKW x 2001-2010 & & $\begin{array}{l}-0.961 \\
(0.651)\end{array}$ & & & \\
\hline Positive SKW & & & $\begin{array}{r}-0.084 \\
(0.321)\end{array}$ & & $\begin{array}{c}0.732 \\
(0.481)\end{array}$ \\
\hline Negative SKW & & & $\begin{array}{c}-0.212 \\
(0.310)\end{array}$ & & $\begin{array}{c}-0.564^{*} \\
(0.317)\end{array}$ \\
\hline SKW $x$ credit change & & & & $\begin{array}{c}-0.003 \\
(0.002)\end{array}$ & \\
\hline Credit change & & & & $\begin{array}{l}-0.030^{* * *} \\
(0.007)\end{array}$ & $\begin{array}{l}-0.009 \\
(0.007)\end{array}$ \\
\hline Positive SKW x credit change & & & & & $\begin{array}{l}-0.013^{* *} \\
(0.005)\end{array}$ \\
\hline Negative SKW x credit change & & & & & $\begin{array}{c}0.008 \\
(0.005)\end{array}$ \\
\hline Observations & 99 & 99 & 99 & 99 & 99 \\
\hline Number of economies & 23 & 23 & 23 & 23 & 23 \\
\hline
\end{tabular}

$\mathrm{GLS}=$ generalized least squares, $\mathrm{OECD}=$ Organisation for Economic Co-operation and Development, $\mathrm{SD}=$ standard deviation, $\mathrm{SKW}=$ skewness. Notes: Standard errors are in parentheses. ${ }^{* *}=p<0.01,{ }^{* *}=p<0.05$, and ${ }^{*}=p<0.1$. Coefficients of the constant, time dummy variables, initial gross domestic product per capita, and initial schooling are not reported here.

Source: Authors' estimates. 
Table 6b: Skewness and Growth of Ranciere, Tornell, and Westermann (2008) Sample, 1971-2016 (Fixed Effects)

\begin{tabular}{|c|c|c|c|c|c|}
\hline \multirow[b]{2}{*}{ Variables } & \multicolumn{5}{|c|}{ Full Sample } \\
\hline & $\begin{array}{c}\text { (1) } \\
\text { Baseline }\end{array}$ & $\begin{array}{c}\text { (2) } \\
\text { Time } \\
\text { Interactions }\end{array}$ & $\begin{array}{c}\text { (3) } \\
\text { Positive or } \\
\text { Negative SKW }\end{array}$ & $\begin{array}{c}\text { (4) } \\
\text { SKW and } \\
\text { Credit Change }\end{array}$ & $\begin{array}{c}\text { (5) } \\
\text { Positive or } \\
\text { Negative SKW and } \\
\text { Credit Change }\end{array}$ \\
\hline Credit growth (mean) & $\begin{array}{l}0.109^{* * *} \\
(0.018)\end{array}$ & $\begin{array}{l}0.195^{* * *} \\
(0.057)\end{array}$ & $\begin{array}{l}0.106^{* * *} \\
(0.017)\end{array}$ & $\begin{array}{l}0.226^{* * *} \\
(0.050)\end{array}$ & $\begin{array}{l}0.214^{* * *} \\
(0.046)\end{array}$ \\
\hline Credit growth (SD) & $\begin{array}{l}-0.037^{* * *} \\
(0.012)\end{array}$ & $\begin{array}{l}0.218^{* * *} \\
(0.068)\end{array}$ & $\begin{array}{l}-0.046^{* * *} \\
(0.015)\end{array}$ & $\begin{array}{l}-0.048^{* * *} \\
(0.017)\end{array}$ & $\begin{array}{l}-0.053^{* * *} \\
(0.018)\end{array}$ \\
\hline Credit growth (SKW) & $\begin{array}{r}0.025 \\
(0.107)\end{array}$ & $\begin{array}{l}1.193^{* * *} \\
(0.411)\end{array}$ & & $\begin{array}{c}0.091 \\
(0.167)\end{array}$ & \\
\hline Credit growth mean x 1971-1980 & & $\begin{array}{l}-0.237^{* * *} \\
(0.084)\end{array}$ & & & \\
\hline Credit growth mean x 1981-1990 & & $\begin{array}{l}-0.071 \\
(0.075)\end{array}$ & & & \\
\hline Credit growth mean x 1991-2000 & & $\begin{array}{l}-0.174^{* * *} \\
(0.059)\end{array}$ & & & \\
\hline Credit growth mean $\times 2001-2010$ & & $\begin{array}{l}-0.089 \\
(0.078)\end{array}$ & & & \\
\hline Credit growth SD x 1971-1980 & & $\begin{array}{l}-0.207^{* * *} \\
(0.073)\end{array}$ & & & \\
\hline Credit growth SD x 1981-1990 & & $\begin{array}{l}-0.303^{* * *} \\
(0.069)\end{array}$ & & & \\
\hline Credit growth SD x 1991-2000 & & $\begin{array}{l}-0.230^{* * *} \\
(0.068)\end{array}$ & & & \\
\hline Credit growth SD x 2001-2010 & & $\begin{array}{l}-0.238^{* * *} \\
(0.073)\end{array}$ & & & \\
\hline Credit growth SKW x 1971-1980 & & $\begin{array}{l}-1.351^{* *} \\
(0.539)\end{array}$ & & & \\
\hline Credit growth SKW x 1981-1990 & & $\begin{array}{l}-1.053^{* *} \\
(0.495)\end{array}$ & & & \\
\hline Credit growth SKW x 1991-2000 & & $\begin{array}{l}-1.010^{*} \\
(0.520)\end{array}$ & & & \\
\hline Credit growth SKW x 2001-2010 & & $\begin{array}{l}-1.205^{* *} \\
(0.451)\end{array}$ & & & \\
\hline Positive SKW & & & $\begin{array}{r}0.352^{*} \\
(0.199)\end{array}$ & & $\begin{array}{r}0.625^{*} \\
(0.324)\end{array}$ \\
\hline Negative SKW & & & $\begin{array}{l}-0.320 \\
(0.199)\end{array}$ & & $\begin{array}{l}-0.367 \\
(0.254)\end{array}$ \\
\hline SKW $x$ credit change & & & & $\begin{array}{l}-0.002 \\
(0.003)\end{array}$ & \\
\hline Credit change & & & & $\begin{array}{l}-0.015^{* *} \\
(0.005)\end{array}$ & $\begin{array}{l}-0.012^{* *} \\
(0.006)\end{array}$ \\
\hline Positive SKW x credit change & & & & & $\begin{array}{l}-0.005 \\
(0.004)\end{array}$ \\
\hline Negative SKW x credit change & & & & & $\begin{array}{l}-0.000 \\
(0.005)\end{array}$ \\
\hline R-squared & 0.375 & 0.551 & 0.385 & 0.402 & 0.405 \\
\hline Observations & 197 & 197 & 197 & 197 & 197 \\
\hline Number of economies & 44 & 44 & 44 & 44 & 44 \\
\hline
\end{tabular}




\begin{tabular}{|c|c|c|c|c|c|}
\hline \multirow[b]{2}{*}{ Variables } & \multicolumn{5}{|c|}{ OECD } \\
\hline & $\begin{array}{c}\text { (6) } \\
\text { Baseline }\end{array}$ & $\begin{array}{c}\text { (7) } \\
\text { Time } \\
\text { Interactions }\end{array}$ & $\begin{array}{c}\text { (8) } \\
\text { Positive or } \\
\text { Negative SKW }\end{array}$ & $\begin{array}{c}\text { (9) } \\
\text { SKW and } \\
\text { Credit Change }\end{array}$ & $\begin{array}{c}\text { (10) } \\
\text { Positive or } \\
\text { Negative SKW and } \\
\text { Credit Change }\end{array}$ \\
\hline Credit growth (mean) & $\begin{array}{l}0.097^{* *} \\
(0.041)\end{array}$ & $\begin{array}{c}0.214^{* *} \\
(0.080)\end{array}$ & $\begin{array}{c}0.096^{* *} \\
(0.040)\end{array}$ & $\begin{array}{c}0.029 \\
(0.077)\end{array}$ & $\begin{array}{c}0.036 \\
(0.077)\end{array}$ \\
\hline Credit growth (SD) & $\begin{array}{l}-0.024^{*} \\
(0.014)\end{array}$ & $\begin{array}{c}0.409 \\
(0.247)\end{array}$ & $\begin{array}{l}-0.026 \\
(0.017)\end{array}$ & $\begin{array}{c}0.003 \\
(0.025)\end{array}$ & $\begin{array}{l}-0.008 \\
(0.024)\end{array}$ \\
\hline Credit growth (SKW) & $\begin{array}{l}-0.033 \\
(0.076)\end{array}$ & $\begin{array}{c}0.407 \\
(0.438)\end{array}$ & & $\begin{array}{c}0.247 \\
(0.200)\end{array}$ & \\
\hline Credit growth mean x 1971-1980 & & $\begin{array}{l}-0.243^{* *} \\
(0.103)\end{array}$ & & & \\
\hline Credit growth mean x 1981-1990 & & $\begin{array}{l}-0.057 \\
(0.114)\end{array}$ & & & \\
\hline Credit growth mean x 1991-2000 & & $\begin{array}{l}-0.118 \\
(0.081)\end{array}$ & & & \\
\hline Credit growth mean $\times 2001-2010$ & & $\begin{array}{l}-0.112 \\
(0.066)\end{array}$ & & & \\
\hline Credit growth SD x 1971-1980 & & $\begin{array}{l}-0.273 \\
(0.243)\end{array}$ & & & \\
\hline Credit growth SD x 1981-1990 & & $\begin{array}{c}-0.510^{* *} \\
(0.243)\end{array}$ & & & \\
\hline Credit growth SD x 1991-2000 & & $\begin{array}{l}-0.413 \\
(0.244)\end{array}$ & & & \\
\hline Credit growth SD x 2001-2010 & & $\begin{array}{c}-0.433^{*} \\
(0.244)\end{array}$ & & & \\
\hline Credit growth SKW x 1971-1980 & & $\begin{array}{l}-0.700 \\
(0.440)\end{array}$ & & & \\
\hline Credit growth SKW x 1981-1990 & & $\begin{array}{l}-0.596 \\
(0.425)\end{array}$ & & & \\
\hline Credit growth SKW x 1991-2000 & & $\begin{array}{l}-0.990^{*} \\
(0.562)\end{array}$ & & & \\
\hline Credit growth SKW x 2001-2010 & & $\begin{array}{l}-0.502 \\
(0.434)\end{array}$ & & & \\
\hline Positive SKW & & & $\begin{array}{c}0.057 \\
(0.186)\end{array}$ & & $\begin{array}{c}0.361 \\
(0.273)\end{array}$ \\
\hline Negative SKW & & & $\begin{array}{l}-0.136 \\
(0.182)\end{array}$ & & $\begin{array}{c}0.153 \\
(0.329)\end{array}$ \\
\hline SKW $x$ credit change & & & & $\begin{array}{l}-0.006 \\
(0.004)\end{array}$ & \\
\hline Credit change & & & & $\begin{array}{c}0.009 \\
(0.009)\end{array}$ & $\begin{array}{c}0.007 \\
(0.007)\end{array}$ \\
\hline Positive SKW x credit change & & & & & $\begin{array}{l}-0.004 \\
(0.005)\end{array}$ \\
\hline Negative SKW $x$ credit change & & & & & $\begin{array}{c}-0.007 \\
(0.009)\end{array}$ \\
\hline R-squared & 0.666 & 0.784 & 0.667 & 0.677 & 0.674 \\
\hline Observations & 98 & 98 & 98 & 98 & 98 \\
\hline Number of economies & 21 & 21 & 21 & 21 & 21 \\
\hline
\end{tabular}




\begin{tabular}{|c|c|c|c|c|c|}
\hline \multirow[b]{2}{*}{ Variables } & \multicolumn{5}{|c|}{ Developing Economies } \\
\hline & $\begin{array}{c}\text { (11) } \\
\text { Baseline }\end{array}$ & $\begin{array}{c}\text { (12) } \\
\text { Time } \\
\text { Interactions }\end{array}$ & $\begin{array}{c}\text { (13) } \\
\text { Positive or } \\
\text { Negative SKW }\end{array}$ & $\begin{array}{c}\text { (14) } \\
\text { SKW and } \\
\text { Credit Change }\end{array}$ & $\begin{array}{c}\text { (15) } \\
\text { Positive or } \\
\text { Negative SKW and } \\
\text { Credit Change }\end{array}$ \\
\hline Credit growth (mean) & $\begin{array}{l}0.052^{* *} \\
(0.024)\end{array}$ & $\begin{array}{l}0.186^{* *} \\
(0.083)\end{array}$ & $\begin{array}{l}0.052^{* *} \\
(0.025)\end{array}$ & $\begin{array}{c}0.177^{* *} \\
(0.084)\end{array}$ & $\begin{array}{l}0.235^{* * *} \\
(0.068)\end{array}$ \\
\hline Credit growth (SD) & $\begin{array}{l}0.006 \\
(0.022)\end{array}$ & $\begin{array}{c}0.074 \\
(0.082)\end{array}$ & $\begin{array}{l}-0.002 \\
(0.024)\end{array}$ & $\begin{array}{l}-0.004 \\
(0.024)\end{array}$ & $\begin{array}{l}-0.064^{* *} \\
(0.026)\end{array}$ \\
\hline Credit growth (SKW) & $\begin{array}{r}0.040 \\
(0.169)\end{array}$ & $\begin{array}{l}1.276^{* *} \\
(0.515)\end{array}$ & & $\begin{array}{c}0.112 \\
(0.199)\end{array}$ & \\
\hline Credit growth mean x 1971-1980 & & $\begin{array}{l}-0.192^{*} \\
(0.098)\end{array}$ & & & \\
\hline Credit growth mean x 1981-1990 & & $\begin{array}{l}-0.083 \\
(0.091)\end{array}$ & & & \\
\hline Credit growth mean x 1991-2000 & & $\begin{array}{l}-0.156 \\
(0.094)\end{array}$ & & & \\
\hline Credit growth mean x 2001-2010 & & $\begin{array}{l}-0.111 \\
(0.107)\end{array}$ & & & \\
\hline Credit growth SD x 1971-1980 & & $\begin{array}{l}-0.032 \\
(0.089)\end{array}$ & & & \\
\hline Credit growth SD x 1981-1990 & & $\begin{array}{l}-0.061 \\
(0.091)\end{array}$ & & & \\
\hline Credit growth SD x 1991-2000 & & $\begin{array}{l}-0.054 \\
(0.093)\end{array}$ & & & \\
\hline Credit growth SD x 2001-2010 & & $\begin{array}{l}-0.119 \\
(0.091)\end{array}$ & & & \\
\hline Credit growth SKW x 1971-1980 & & $\begin{array}{l}-1.928^{* * *} \\
(0.618)\end{array}$ & & & \\
\hline Credit growth SKW x 1981-1990 & & $\begin{array}{l}-1.369^{* *} \\
(0.628)\end{array}$ & & & \\
\hline Credit growth SKW x 1991-2000 & & $\begin{array}{l}-0.968 \\
(0.636)\end{array}$ & & & \\
\hline Credit growth SKW x 2001-2010 & & $\begin{array}{l}-1.631^{* *} \\
(0.620)\end{array}$ & & & \\
\hline Positive SKW & & & $\begin{array}{c}0.367 \\
(0.317)\end{array}$ & & $\begin{array}{l}0.909^{*} \\
(0.515)\end{array}$ \\
\hline Negative SKW & & & $\begin{array}{l}-0.285 \\
(0.233)\end{array}$ & & $\begin{array}{l}-0.626^{*} \\
(0.316)\end{array}$ \\
\hline SKW $x$ credit change & & & & $\begin{array}{l}-0.001 \\
(0.003)\end{array}$ & \\
\hline Credit change & & & & $\begin{array}{l}-0.014^{*} \\
(0.008)\end{array}$ & $\begin{array}{l}-0.014 \\
(0.009)\end{array}$ \\
\hline Positive SKW x credit change & & & & & $\begin{array}{l}-0.009 \\
(0.007)\end{array}$ \\
\hline Negative SKW x credit change & & & & & $\begin{array}{c}0.001 \\
(0.005)\end{array}$ \\
\hline R-squared & 0.524 & 0.632 & 0.532 & 0.540 & 0.378 \\
\hline Observations & 99 & 99 & 99 & 99 & 99 \\
\hline Number of economies & 23 & 23 & 23 & 23 & 23 \\
\hline
\end{tabular}

OECD = Organisation for Economic Co-operation and Development, $\mathrm{SD}=$ standard deviation, $\mathrm{SKW}=$ skewness .

Notes: Standard errors are in parentheses. ${ }^{* *}=p<0.01,{ }^{* *}=p<0.05$, and ${ }^{*}=p<0.1$. Coefficients of the constant, time dummy variables, initial gross domestic product per capita, and initial schooling are not reported here.

Source: Authors' estimates. 


\section{Credit Skewness and Higher Moments of Output Growth}

To better understand the mechanism by which skewness of credit growth affects output growth, we also examine the link between skewness of credit growth on one hand and higher moments of output growth on the other. We present the results in Table 7.

We observe that the relation between credit skewness and growth for higher moments is different between OECD and developing economies. For 1971-2000, we do find a significant negative relationship between skewness of credit growth and skewness of GDP growth in OECD economies (Table 7a, column [3]), but not in developing economies. Remarkably, in the extended sample (1971-2016) while we observe a strong negative relation between credit skewness and the standard deviation of growth for developing economies for the full sample period (Table 7b, column [6]), our results point toward a weaker relation between credit skewness and standard deviation of output growth in advanced economies (Table 7b, column [4]). A summary of the relationships is shown in Table 8, which contains the relationship for the full sample in column (1), OECD sample in column (2), and developing economy sample in column (3).

\section{Table 7: Skewness and Standard Deviation of Gross Domestic Product Growth as Dependent Variables}

A. Ranciere, Tornell, and Westermann (2008) Sample, 1971-2000

\begin{tabular}{|c|c|c|c|c|c|c|}
\hline \multirow[b]{2}{*}{ Variables } & \multicolumn{2}{|c|}{ Full Sample } & \multicolumn{2}{|c|}{ OECD } & \multicolumn{2}{|c|}{ Developing Economies } \\
\hline & $\begin{array}{l}\text { (1) } \\
\text { SKW of GDP } \\
\text { Growth as } \\
\text { DV }\end{array}$ & $\begin{array}{l}\text { (2) } \\
\text { SD of GDP } \\
\text { Growth } \\
\text { as DV }\end{array}$ & $\begin{array}{l}\text { (3) } \\
\text { SKW of GDP } \\
\text { Growth } \\
\text { as DV }\end{array}$ & $\begin{array}{l}\text { (4) } \\
\text { SD of GDP } \\
\text { Growth } \\
\text { as DV }\end{array}$ & $\begin{array}{l}\text { (5) } \\
\text { SKW of GDP } \\
\text { Growth } \\
\text { as DV }\end{array}$ & $\begin{array}{l}\text { (6) } \\
\text { SD of GDP } \\
\text { Growth } \\
\text { as DV }\end{array}$ \\
\hline Credit growth (mean) & $\begin{array}{l}0.027^{* * *} \\
(0.008)\end{array}$ & $\begin{array}{l}-0.059^{* * *} \\
(0.015)\end{array}$ & $\begin{array}{l}-0.007 \\
(0.010)\end{array}$ & $\begin{array}{l}-0.036^{*} \\
(0.021)\end{array}$ & $\begin{array}{c}0.018 \\
(0.012)\end{array}$ & $\begin{array}{l}-0.065^{* * *} \\
(0.022)\end{array}$ \\
\hline Credit growth (SD) & $\begin{array}{l}-0.008^{* *} \\
(0.004)\end{array}$ & $\begin{array}{l}0.025^{* * *} \\
(0.009)\end{array}$ & $\begin{array}{l}0.010^{* * *} \\
(0.003)\end{array}$ & $\begin{array}{c}0.003 \\
(0.007)\end{array}$ & $\begin{array}{l}-0.014^{*} \\
(0.008)\end{array}$ & $\begin{array}{c}0.019 \\
(0.021)\end{array}$ \\
\hline Credit growth (SKW) & $\begin{array}{l}-0.085 \\
(0.060)\end{array}$ & $\begin{array}{l}-0.078 \\
(0.091)\end{array}$ & $\begin{array}{l}-0.174^{* *} \\
(0.070)\end{array}$ & $\begin{array}{c}0.117 \\
(0.097)\end{array}$ & $\begin{array}{l}-0.064 \\
(0.082)\end{array}$ & $\begin{array}{c}0.120 \\
(0.177)\end{array}$ \\
\hline Initial income per capita & $\begin{array}{l}-0.122^{* * *} \\
(0.025)\end{array}$ & $\begin{array}{l}-0.176^{* * *} \\
(0.037)\end{array}$ & $\begin{array}{l}-0.060^{* * *} \\
(0.023)\end{array}$ & $\begin{array}{l}-0.330^{* * *} \\
(0.034)\end{array}$ & $\begin{array}{l}-0.110^{* *} \\
(0.051)\end{array}$ & $\begin{array}{l}-0.018 \\
(0.084)\end{array}$ \\
\hline Initial schooling & $\begin{array}{c}0.003^{*} \\
(0.002)\end{array}$ & $\begin{array}{l}-0.010^{* * *} \\
(0.003)\end{array}$ & $\begin{array}{l}0.013^{* * *} \\
(0.002)\end{array}$ & $\begin{array}{l}-0.021^{1 * *} \\
(0.005)\end{array}$ & $\begin{array}{c}0.002 \\
(0.004)\end{array}$ & $\begin{array}{c}0.010 \\
(0.009)\end{array}$ \\
\hline Time dummy, 1971-1980 & $\begin{array}{c}0.199^{*} \\
(0.103)\end{array}$ & $\begin{array}{l}0.345^{*} \\
(0.181)\end{array}$ & $\begin{array}{l}0.403^{* * *} \\
(0.082)\end{array}$ & $\begin{array}{c}0.176 \\
(0.201)\end{array}$ & $\begin{array}{r}0.265 \\
(0.181)\end{array}$ & $\begin{array}{c}0.370 \\
(0.377)\end{array}$ \\
\hline Time dummy, 1981-1990 & $\begin{array}{l}0.237^{* *} \\
(0.094)\end{array}$ & $\begin{array}{c}0.114 \\
(0.142)\end{array}$ & $\begin{array}{l}0.679^{* * *} \\
(0.062)\end{array}$ & $\begin{array}{l}-0.155 \\
(0.144)\end{array}$ & $\begin{array}{l}-0.141 \\
(0.157)\end{array}$ & $\begin{array}{c}0.336 \\
(0.300)\end{array}$ \\
\hline Constant & $\begin{array}{l}2.282^{* * *} \\
(0.569)\end{array}$ & $\begin{array}{l}7.779^{* * *} \\
(0.879)\end{array}$ & $\begin{array}{l}-0.343 \\
(0.744)\end{array}$ & $\begin{array}{l}12.763^{* * *} \\
(1.060)\end{array}$ & $\begin{array}{l}2.356^{* *} \\
(1.124)\end{array}$ & $\begin{array}{l}3.504^{*} \\
(1.889)\end{array}$ \\
\hline $\begin{array}{l}\text { Observations } \\
\text { Number of economies }\end{array}$ & $\begin{array}{c}120 \\
44\end{array}$ & $\begin{array}{l}120 \\
44\end{array}$ & $\begin{array}{l}58 \\
21\end{array}$ & $\begin{array}{l}58 \\
21\end{array}$ & $\begin{array}{l}62 \\
23\end{array}$ & $\begin{array}{l}62 \\
23\end{array}$ \\
\hline
\end{tabular}


B. Extended Sample, 1971-2016

\begin{tabular}{|c|c|c|c|c|c|c|}
\hline \multirow[b]{2}{*}{ Variables } & \multicolumn{2}{|c|}{ Full Sample } & \multicolumn{2}{|c|}{ OECD } & \multicolumn{2}{|c|}{ Developing Economies } \\
\hline & $\begin{array}{c}\text { (1) } \\
\text { SKW of GDP } \\
\text { Growth as } \\
\text { DV }\end{array}$ & $\begin{array}{c}\text { (2) } \\
\text { SD of GDP } \\
\text { Growth } \\
\text { as DV }\end{array}$ & $\begin{array}{c}\text { (3) } \\
\text { SKW of GDP } \\
\text { Growth } \\
\text { as DV }\end{array}$ & $\begin{array}{c}\text { (4) } \\
\text { SD of GDP } \\
\text { Growth } \\
\text { as DV }\end{array}$ & $\begin{array}{c}\text { (5) } \\
\text { SKW of GDP } \\
\text { Growth } \\
\text { as DV }\end{array}$ & $\begin{array}{l}\text { (6) } \\
\text { SD of GDP } \\
\text { Growth } \\
\text { as DV }\end{array}$ \\
\hline Credit growth (mean) & $\begin{array}{l}0.016^{* * *} \\
(0.004)\end{array}$ & $\begin{array}{l}-0.022^{* * *} \\
(0.008)\end{array}$ & $\begin{array}{l}-0.007 \\
(0.012)\end{array}$ & $\begin{array}{l}-0.044^{* * *} \\
(0.014)\end{array}$ & $\begin{array}{l}0.019^{* * *} \\
(0.005)\end{array}$ & $\begin{array}{l}-0.027^{* *} \\
(0.012)\end{array}$ \\
\hline Credit growth (SD) & $\begin{array}{l}-0.013^{* * *} \\
(0.003)\end{array}$ & $\begin{array}{l}0.048^{* * *} \\
(0.006)\end{array}$ & $\begin{array}{c}0.002 \\
(0.006)\end{array}$ & $\begin{array}{l}0.018^{* *} \\
(0.007)\end{array}$ & $\begin{array}{l}-0.019^{* * *} \\
(0.003)\end{array}$ & $\begin{array}{l}0.061^{* * *} \\
(0.010)\end{array}$ \\
\hline Credit growth (SKW) & $\begin{array}{l}0.091^{* *} \\
(0.037)\end{array}$ & $\begin{array}{l}-0.358^{* * *} \\
(0.052)\end{array}$ & $\begin{array}{r}0.058 \\
(0.077)\end{array}$ & $\begin{array}{r}-0.092 \\
(0.074)\end{array}$ & $\begin{array}{c}0.061 \\
(0.042)\end{array}$ & $\begin{array}{l}-0.269^{* * *} \\
(0.097)\end{array}$ \\
\hline Initial income per capita & $\begin{array}{l}-0.064^{* * *} \\
(0.014)\end{array}$ & $\begin{array}{l}-0.225^{* * *} \\
(0.019)\end{array}$ & $\begin{array}{l}-0.054^{*} \\
(0.030)\end{array}$ & $\begin{array}{l}-0.302^{* * *} \\
(0.029)\end{array}$ & $\begin{array}{l}-0.071^{* * *} \\
(0.019)\end{array}$ & $\begin{array}{l}-0.145^{* * *} \\
(0.035)\end{array}$ \\
\hline Initial schooling & $\begin{array}{l}-0.002^{*} \\
(0.001)\end{array}$ & $\begin{array}{l}-0.003^{*} \\
(0.002)\end{array}$ & $\begin{array}{c}0.003 \\
(0.003)\end{array}$ & $\begin{array}{l}-0.016^{* * *} \\
(0.004)\end{array}$ & $\begin{array}{l}-0.001 \\
(0.001)\end{array}$ & $\begin{array}{c}0.001 \\
(0.003)\end{array}$ \\
\hline Time dummy, 1971-1980 & $\begin{array}{r}-0.123 \\
(0.105)\end{array}$ & $\begin{array}{l}1.018^{* * *} \\
(0.159)\end{array}$ & $\begin{array}{l}-0.411^{* *} \\
(0.195)\end{array}$ & $\begin{array}{l}0.683^{* * *} \\
(0.221)\end{array}$ & $\begin{array}{c}0.206 \\
(0.131)\end{array}$ & $\begin{array}{l}1.354^{* * *} \\
(0.327)\end{array}$ \\
\hline Time dummy, 1981-1990 & $\begin{array}{l}-0.163^{*} \\
(0.096)\end{array}$ & $\begin{array}{l}0.679^{* * *} \\
(0.132)\end{array}$ & $\begin{array}{c}0.112 \\
(0.174)\end{array}$ & $\begin{array}{l}0.389^{* *} \\
(0.166)\end{array}$ & $\begin{array}{r}-0.076 \\
(0.115)\end{array}$ & $\begin{array}{l}1.112^{* * *} \\
(0.280)\end{array}$ \\
\hline Time dummy, 1991-2000 & $\begin{array}{l}-0.255^{* * *} \\
(0.092)\end{array}$ & $\begin{array}{l}0.463^{* * *} \\
(0.120)\end{array}$ & $\begin{array}{l}-0.470^{* * *} \\
(0.162)\end{array}$ & $\begin{array}{l}0.325^{* *} \\
(0.157)\end{array}$ & $\begin{array}{r}0.002 \\
(0.107)\end{array}$ & $\begin{array}{l}0.645^{* *} \\
(0.255)\end{array}$ \\
\hline Time dummy, 2001-2010 & $\begin{array}{l}-0.511^{* * *} \\
(0.091)\end{array}$ & $\begin{array}{l}0.629^{* * *} \\
(0.121)\end{array}$ & $\begin{array}{l}-0.981^{* * *} \\
(0.162)\end{array}$ & $\begin{array}{l}1.313^{* * *} \\
(0.126)\end{array}$ & $\begin{array}{l}-0.180^{*} \\
(0.107)\end{array}$ & $\begin{array}{l}0.555^{* *} \\
(0.234)\end{array}$ \\
\hline Constant & $\begin{array}{l}1.588^{* * *} \\
(0.319)\end{array}$ & $\begin{array}{l}7.749^{* * *} \\
(0.476)\end{array}$ & $\begin{array}{c}0.945 \\
(0.860)\end{array}$ & $\begin{array}{l}11.206^{* * *} \\
(0.722)\end{array}$ & $\begin{array}{c}1.592^{* * *} \\
(0.460)\end{array}$ & $\begin{array}{l}5.315^{* * *} \\
(0.891)\end{array}$ \\
\hline $\begin{array}{l}\text { Observations } \\
\text { Number of economies }\end{array}$ & $\begin{array}{c}328 \\
82\end{array}$ & $\begin{array}{c}328 \\
82\end{array}$ & $\begin{array}{l}114 \\
26\end{array}$ & $\begin{array}{l}114 \\
26\end{array}$ & $\begin{array}{c}214 \\
56\end{array}$ & $\begin{array}{c}214 \\
56\end{array}$ \\
\hline
\end{tabular}

$\mathrm{DV}=$ dependent variable, $\mathrm{GDP}=$ gross domestic product, $\mathrm{OECD}=$ Organisation for Economic Co-operation and Development, $\mathrm{SD}=$ standard deviation, SKW = skewness.

Notes: Standard errors in parentheses. ${ }^{* *}=p<0.01,{ }^{* *}=p<0.05$, and ${ }^{*}=p<0.1$.

Source: Authors' estimates.

Bekaert and Popov (2012) find a negative correlation between GDP growth's standard deviation and skewness, while Salgado, Guvenen, and Bloom (2015) finds a positive correlation between growth's mean and skewness. These findings are consistent with our own results, which show that credit skewness both negatively relates to average growth and positively relates to the skewness of GDP growth. We read these results as explaining the correlation between average growth and growth skewness documented in Salgado, Guvenen, and Bloom (2015). Such a relationship is due to the forces of credit dynamics. 


\section{Table 8: Summary of Results for Skewness and Standard Deviation of Gross Domestic Product per Capita Growth and Credit Growth}

\begin{tabular}{lccc}
\hline Variables & Full Sample & OECD & Developing Economies \\
(1) & $>0^{*}(1971-2000)$ & $<0^{*}(1971-2000)$ & $\approx 0$ \\
GDP growth SKW and credit growth SKW & $<0^{* * *}(1971-2016)$ & $\approx 0$ & $<0^{* *}(1971-2016)$ \\
\hline
\end{tabular}

$\mathrm{GDP}=$ gross domestic product, $\mathrm{OECD}=$ Organisation for Economic Co-operation and Development, $\mathrm{SD}=$ standard deviation, $\mathrm{SKW}=$ skewness. Note: $>0^{*}=$ positive and significant at 10\%, < $0^{*}=$ negative and significant at $10 \%,<0^{* *}=$ negative and significant at $5 \%,<0^{* * *}=$ negative and significant at $1 \%, \approx 0=$ insignificant.

Source: Authors' estimates.

\section{CONCLUSIONS}

While a large empirical literature finds that deeper financial systems can be beneficial for growth, some empirical evidence shows that financial systems can be a major source of instability that can seriously harm economic growth. A good example is the 2008-2009 global financial crisis that paralyzed the global financial system and wrought havoc on the world economy. This paper contributes to the long-running debate on the finance-growth relationship by revisiting the link between skewness in real credit growth and long-run economic growth. The influential study of Ranciere, Tornell, and Westermann (2008) has shown that, on average, economies that are characterized by negative skewness in private sector credit growth experience faster output growth. They argue that negative skewness is a proxy for systemic risk-taking, which helps economies with weak institutions to overcome institutional problems and achieve faster growth. However, once economies build up strong institutions, they are likely to be better off on a safe mode.

In this paper, we empirically reexamine whether this relationship still holds even after we account for the global financial crisis. Our results show that while more credit is associated with higher economic growth, more frequent credit shocks can be bad for economic growth. We find that financial crises, as measured by credit skewness, prior to 2000 are positively associated with growth, but after 2000 this relationship weakened. The weakening was largely driven by our evidence for advanced economies, which, in turn, could reflect differences between the types and sources of financial risk that materialized before 2000 versus those that materialized during the global financial crisis. Financial crises in the past often emanated in developing economies and their effects were largely confined to those economies. In contrast, the global financial crisis broke out in advanced economies and its effects were felt across the world. For developing economies, we do find that there is a negative link between skewness and growth in some decades. This may imply that they have been subject to credit busts, which allowed for cleansing and creative destruction, and, more broadly, greater economic dynamism. The somewhat weak relationship between financial skewness and growth may be influenced by two caveats. One is that crises need not always imply negative skewness. Another is that negative skewness can capture credit growth busts, stagnation, or deceleration, each of which is likely to have different effects on growth.

In addition, our paper explored whether the link between credit growth skewness and economic growth differs depending on whether skewness is positive or negative. Prior to 2000, there is some evidence that negative skewness is directly associated with growth while positive skewness is inversely linked with growth for the full sample and advanced economy subsample, although the results are not robust across specifications. However, when we look at the longer period of 1971-2016, the differential effects between positive and negative skewness disappear. 


\section{APPENDIX}

Table A1: Data Description and Sources

\begin{tabular}{lll}
\hline Data, 1971-2016 & \multicolumn{1}{c}{ Definition } & Source \\
\hline Private credit growth & $\begin{array}{l}\text { Calculated from IFS data that refer to claims on the private } \\
\text { sector from a survey of other depository corporations, which } \\
\text { excludes the central bank; other financial corporations, } \\
\text { insurance corporations, and pension funds; other financial } \\
\text { intermediaries; and financial auxiliaries }\end{array}$ & IFS \\
& $\begin{array}{l}\text { To get real private credit, data are deflated by end-of-year } \\
\text { Consumer Price Index data from IFS. }\end{array}$ & \\
GDP per capita growth & $\begin{array}{l}\text { Calculated from GDP per capita (constant 2005 dollars) } \\
\text { Initial income }\end{array}$ & $\begin{array}{l}\text { GDP per capita (constant 2005 dollars) at the start } \\
\text { of the decade }\end{array}$ \\
Initial schooling & $\begin{array}{l}\text { School enrollment, secondary (\% gross), which refers to the } \\
\text { ratio of total secondary enrollment to the population of the } \\
\text { age group }\end{array}$ & World Bank's WDI \\
\hline
\end{tabular}

GDP = gross domestic product, IFS = International Financial Statistics, WDI = World Development Indicators.

Source: Authors' compilation. 
Table A2a: Descriptive Statistics, Ranciere, Tornell, and Westermann (2008) Sample (44 Economies)

\begin{tabular}{|c|c|c|c|c|c|c|c|c|c|c|c|c|c|c|c|}
\hline & \multicolumn{5}{|c|}{$1971-2016$} & \multicolumn{5}{|c|}{$1971-2000$} & \multicolumn{5}{|c|}{ 2001-2016 } \\
\hline & Obs. & Mean & $S D$ & Min & Max & Obs. & Mean & $S D$ & Min & Max & Obs. & Mean & $S D$ & Min & Max \\
\hline \multicolumn{16}{|l|}{ All } \\
\hline Real GDPPC growth & 197 & 3.259 & 1.999 & -3.385 & 10.328 & 120 & 3.484 & 1.952 & -0.109 & 10.328 & 74 & 2.908 & 2.069 & -3.385 & 7.245 \\
\hline Mean real credit growth & 197 & 6.424 & 6.220 & -6.802 & 28.912 & 120 & 6.744 & 6.394 & -4.489 & 28.912 & 74 & 5.803 & 6.014 & -6.802 & 26.667 \\
\hline SD of real credit growth & 197 & 10.431 & 10.513 & 0.392 & 97.724 & & 12.531 & 11.790 & 2.014 & 97.724 & 74 & 6.974 & 6.904 & 0.392 & 40.394 \\
\hline SKW of real credit growth & 197 & 0.115 & 0.860 & -2.392 & 2.640 & 120 & 0.237 & 0.858 & -1.808 & 2.628 & 74 & -0.091 & 0.812 & -2.392 & 2.640 \\
\hline Initial GDP per capita (In) & 197 & 25.223 & 2.253 & 19.141 & 30.337 & 120 & 24.817 & 2.294 & 19.141 & 29.835 & 74 & 25.874 & 2.042 & 22.020 & 30.337 \\
\hline Initial schooling & 197 & 68.547 & 35.301 & 1.004 & 153.784 & 120 & 57.477 & 33.440 & 1.004 & 118.483 & 74 & 85.395 & 31.528 & 6.948 & 153.784 \\
\hline \multicolumn{16}{|l|}{ OECD } \\
\hline Real GDPPC growth & 98 & 2.498 & 1.724 & -3.385 & 9.450 & 58 & 3.153 & 1.632 & 0.684 & 9.450 & 38 & 1.502 & 1.413 & -3.385 & 4.327 \\
\hline Mean real credit growth & 98 & 5.400 & 5.829 & -6.802 & 28.912 & 58 & 6.800 & 5.790 & -4.186 & 28.912 & 38 & 3.088 & 5.269 & -6.802 & 18.845 \\
\hline SD of real credit growth & 98 & 7.958 & 12.193 & 0.392 & 97.724 & 58 & 9.411 & 14.378 & 2.014 & 97.724 & 38 & 5.396 & 7.364 & 0.392 & 40.394 \\
\hline SKW of real credit growth & 98 & 0.151 & 0.890 & -2.392 & 2.640 & 58 & 0.311 & 0.863 & -1.217 & 2.628 & 38 & -0.127 & 0.845 & -2.392 & 2.640 \\
\hline Initial GDPPC (In) & 98 & 26.681 & 1.472 & 22.570 & 30.337 & 58 & 26.452 & 1.436 & 22.570 & 29.835 & 38 & 27.029 & 1.487 & 23.055 & 30.337 \\
\hline Initial schooling & 98 & 95.021 & 18.901 & 37.535 & 153.784 & 58 & 86.030 & 16.190 & 37.535 & 118.483 & 38 & 108.162 & 14.865 & 87.100 & 153.784 \\
\hline \multicolumn{16}{|l|}{ Developing Economies } \\
\hline Real GDPPC growth & 99 & 4.014 & 1.974 & -0.109 & 10.328 & 62 & 3.794 & 2.179 & -0.109 & 10.328 & 36 & 4.392 & 1.551 & 0.667 & 7.245 \\
\hline Mean real credit growth & 99 & 7.438 & 6.455 & -4.489 & 26.829 & 62 & 6.693 & 6.958 & -4.489 & 26.829 & 36 & 8.670 & 5.444 & -2.263 & 26.667 \\
\hline SD of real credit growth & 99 & 12.880 & 7.855 & 2.083 & 45.906 & 62 & 15.450 & 7.752 & 5.367 & 45.906 & 36 & 8.640 & 6.045 & 2.083 & 25.181 \\
\hline SKW of real credit growth & 99 & 0.079 & 0.831 & -1.808 & 2.151 & 62 & 0.167 & 0.855 & -1.808 & 2.151 & 36 & -0.054 & 0.785 & -1.605 & 1.316 \\
\hline Initial GDPPC (In) & 99 & 23.781 & 1.945 & 19.141 & 28.136 & 62 & 23.288 & 1.851 & 19.141 & 27.152 & 36 & 24.654 & 1.839 & 22.020 & 28.136 \\
\hline Initial schooling & 99 & 42.341 & 27.278 & 1.004 & 102.185 & 62 & 30.766 & 20.885 & 1.004 & 81.211 & 36 & 61.364 & 26.131 & 6.948 & 102.185 \\
\hline
\end{tabular}

GDPPC = gross domestic product per capita, Obs. = observations, $\mathrm{OECD}=$ Organisation for Economic Co-operation and Development, $\mathrm{SD}=$ standard deviation, $\mathrm{SKW}=$ skewness.

Source: Authors' estimates. 
Table A2b: Descriptive Statistics, Extended Sample (82 Economies)

\begin{tabular}{|c|c|c|c|c|c|c|c|c|c|c|c|c|c|c|c|}
\hline & \multicolumn{5}{|c|}{ 1971-2016 } & \multicolumn{5}{|c|}{$1971-2000$} & \multicolumn{5}{|c|}{$2001-2016$} \\
\hline & Obs. & Mean & SD & Min & Max & Obs. & Mean & SD & Min & Max & Obs. & Mean & SD & Min & Max \\
\hline \multicolumn{16}{|l|}{ All } \\
\hline Real GDPPC growth & 328 & 3.340 & 2.295 & -8.047 & 11.312 & 184 & 3.429 & 2.276 & -8.047 & 10.328 & 144 & 3.226 & 2.322 & -3.385 & 11.312 \\
\hline Mean real credit growth & 328 & 7.182 & 7.994 & -13.633 & 78.074 & 184 & 7.068 & 8.175 & -13.633 & 78.074 & 144 & 7.329 & 7.781 & -6.802 & 38.088 \\
\hline SD of real credit growth & 328 & 11.869 & 13.438 & 0.392 & 165.574 & 184 & 14.353 & 16.283 & 2.014 & 165.574 & 144 & 8.694 & 7.451 & 0.392 & 40.394 \\
\hline SKW of real credit growth & 328 & 0.157 & 0.823 & -2.392 & 2.640 & 184 & 0.241 & 0.826 & -1.808 & 2.628 & 144 & 0.050 & 0.808 & -2.392 & 2.640 \\
\hline Initial GDPPC (In) & 328 & 24.365 & 2.532 & 19.141 & 30.337 & 184 & 24.009 & 2.491 & 19.141 & 29.835 & 144 & 24.819 & 2.521 & 19.588 & 30.337 \\
\hline Initial schooling & 328 & 66.908 & 33.923 & 1.004 & 153.784 & 184 & 55.765 & 32.762 & 1.004 & 118.483 & 144 & 81.146 & 29.899 & 6.948 & 153.784 \\
\hline \multicolumn{16}{|l|}{ OECD } \\
\hline Real GDPPC growth & 114 & 2.509 & 1.640 & -3.385 & 9.450 & 64 & 3.135 & 1.583 & 0.684 & 9.450 & 50 & 1.707 & 1.346 & -3.385 & 4.327 \\
\hline Mean real credit growth & 114 & 5.331 & 5.693 & -6.802 & 28.912 & 64 & 6.803 & 5.703 & -4.186 & 28.912 & 50 & 3.448 & 5.145 & -6.802 & 18.845 \\
\hline SD of real credit growth & 114 & 8.114 & 11.669 & 0.392 & 97.724 & 64 & 9.816 & 14.035 & 2.014 & 97.724 & 50 & 5.936 & 7.219 & 0.392 & 40.394 \\
\hline SKW of real credit growth & 114 & 0.145 & 0.887 & -2.392 & 2.640 & 64 & 0.338 & 0.875 & -1.217 & 2.628 & 50 & -0.101 & 0.848 & -2.392 & 2.640 \\
\hline Initial GDPPC (In) & 114 & 26.655 & 1.532 & 22.570 & 30.337 & 64 & 26.395 & 1.517 & 22.570 & 29.835 & 50 & 26.987 & 1.501 & 23.055 & 30.337 \\
\hline Initial schooling & 114 & 94.472 & 18.444 & 37.535 & 153.784 & 64 & 85.330 & 16.488 & 37.535 & 118.483 & 50 & 106.173 & 13.644 & 87.100 & 153.784 \\
\hline \multicolumn{16}{|l|}{ Developing Economies } \\
\hline Real GDPPC growth & 214 & 3.783 & 2.468 & -8.047 & 11.312 & 120 & 3.585 & 2.563 & -8.047 & 10.328 & 94 & 4.034 & 2.331 & -1.541 & 11.312 \\
\hline Mean real credit growth & 214 & 8.168 & 8.837 & -13.633 & 78.074 & 120 & 7.209 & 9.247 & -13.633 & 78.074 & 94 & 9.393 & 8.170 & -5.819 & 38.088 \\
\hline SD of real credit growth & 214 & 13.869 & 13.908 & 1.768 & 165.574 & 120 & 16.773 & 16.926 & 2.458 & 165.574 & 94 & 10.161 & 7.186 & 1.768 & 32.080 \\
\hline SKW of real credit growth & 214 & 0.164 & 0.789 & -1.808 & 2.347 & 120 & 0.190 & 0.798 & -1.808 & 2.347 & 94 & 0.131 & 0.779 & -1.605 & 2.170 \\
\hline Initial GDPPC (In) & 214 & 23.145 & 2.073 & 19.141 & 29.439 & 120 & 22.737 & 1.905 & 19.141 & 27.444 & 94 & 23.666 & 2.171 & 19.588 & 29.439 \\
\hline Initial schooling & 214 & 52.224 & 31.031 & 1.004 & 111.029 & 120 & 39.996 & 28.033 & 1.004 & 111.029 & 94 & 67.834 & 27.579 & 6.948 & 107.799 \\
\hline
\end{tabular}


Table A3: Descriptive Statistics on Skewness and Standard Deviation of Gross Domestic Product per Capita Growth

\begin{tabular}{|c|c|c|c|c|c|c|c|c|c|c|c|c|c|c|c|}
\hline & \multicolumn{5}{|c|}{ 1971-2016 } & \multicolumn{5}{|c|}{$1971-2000$} & \multicolumn{5}{|c|}{ 2001-2016 } \\
\hline & Obs. & Mean & SD & Min & Max & Obs. & Mean & SD & Min & Max & Obs. & Mean & SD & Min & Max \\
\hline \multicolumn{16}{|c|}{ Ranciere, Tornell, and Westermann (2008) } \\
\hline \multicolumn{16}{|l|}{ All } \\
\hline SKW of GDPPC growth & 197 & -0.414 & 0.754 & -2.445 & 2.269 & 120 & -0.383 & 0.781 & -2.445 & 2.269 & 77 & -0.464 & 0.711 & -1.987 & 0.984 \\
\hline $\begin{array}{l}\text { SD of GDPPC growth } \\
\text { OECD }\end{array}$ & 197 & 2.702 & 1.565 & 0.365 & 9.484 & 120 & 3.057 & 1.634 & 0.622 & 9.484 & 77 & 2.148 & 1.274 & 0.365 & 5.503 \\
\hline SKW of GDPPC growth & 98 & -0.512 & 0.684 & -2.060 & 0.958 & 58 & -0.454 & 0.637 & -2.060 & 0.710 & 40 & -0.596 & 0.747 & -1.987 & 0.958 \\
\hline SD of GDPPC growth & 98 & 0.021 & 0.011 & 0.004 & 0.064 & 58 & 0.022 & 0.011 & 0.007 & 0.064 & 40 & 0.019 & 0.011 & 0.004 & 0.051 \\
\hline \multicolumn{16}{|l|}{ Developing Economies } \\
\hline SKW of GDPPC growth & 99 & -0.318 & 0.809 & -2.445 & 2.269 & 62 & -0.317 & 0.895 & -2.445 & 2.269 & 37 & -0.320 & 0.649 & -1.539 & 0.984 \\
\hline SD of GDPPC growth & 99 & 0.033 & 0.017 & 0.004 & 0.091 & 62 & 0.038 & 0.017 & 0.017 & 0.091 & 37 & 0.024 & 0.014 & 0.004 & 0.055 \\
\hline \multicolumn{16}{|l|}{ Extended Sample } \\
\hline \multicolumn{16}{|l|}{ All } \\
\hline SKW of GDPPC growth & 328 & -0.345 & 0.764 & -2.445 & 2.269 & 184 & -0.341 & 0.765 & -2.445 & 2.269 & 144 & -0.350 & 0.766 & -1.987 & 1.577 \\
\hline SD of GDPPC growth & 328 & 0.031 & 0.020 & 0.002 & 0.152 & 184 & 0.035 & 0.020 & 0.007 & 0.141 & 144 & 0.025 & 0.019 & 0.002 & 0.152 \\
\hline \multicolumn{16}{|l|}{ OECD } \\
\hline SKW of GDPPC growth & 114 & -0.515 & 0.720 & -2.211 & 0.958 & 64 & -0.481 & 0.671 & -2.211 & 0.710 & 50 & -0.559 & 0.782 & -1.987 & 0.958 \\
\hline SD of GDPPC growth & 114 & 0.021 & 0.011 & 0.004 & 0.064 & 64 & 0.023 & 0.011 & 0.007 & 0.064 & 50 & 0.020 & 0.011 & 0.004 & 0.051 \\
\hline \multicolumn{16}{|l|}{ Developing Economies } \\
\hline SKW of GDPPC growth & 214 & -0.255 & 0.773 & -2.445 & 2.269 & 120 & -0.267 & 0.803 & -2.445 & 2.269 & 94 & -0.239 & 0.737 & -1.967 & 1.577 \\
\hline SD of GDPPC growth & 214 & 0.036 & 0.022 & 0.002 & 0.152 & 120 & 0.041 & 0.021 & 0.008 & 0.141 & 94 & 0.028 & 0.021 & 0.002 & 0.152 \\
\hline
\end{tabular}

GDPPC = gross domestic product per capita, Obs. = observations, $\mathrm{OECD}=$ Organisation for Economic Co-operation and Development, $\mathrm{SD}=$ standard deviation, $\mathrm{SKW}=\mathrm{skewness}$. Source: Authors' estimates. 
Table A4: Credit Skewness and Economic Growth-Extended Sample

\begin{tabular}{|c|c|c|c|c|c|c|c|c|c|c|c|c|}
\hline & \multirow{2}{*}{\multicolumn{2}{|c|}{ Economy }} & \multicolumn{5}{|c|}{ Credit Skewness } & \multicolumn{5}{|c|}{ Mean GDP per Capita Growth } \\
\hline & & & 1971-1980 & 1981-1990 & 1991-2000 & 2001-2010 & 2011-2016 & $1971-1980$ & 1981-1990 & 1991-2000 & 2001-2010 & 2011-2016 \\
\hline $\begin{array}{l}1 \\
2\end{array}$ & $\begin{array}{l}\text { Austria } \\
\text { Bahamas, The }\end{array}$ & * & $\begin{array}{l}-0.266 \\
0.115\end{array}$ & $\begin{array}{l}0.157 \\
0.789\end{array}$ & $\begin{array}{l}0.431 \\
0.425\end{array}$ & 1.333 & -0.168 & $\begin{array}{l}3.544 \\
3.691\end{array}$ & $\begin{array}{l}2.223 \\
3.021\end{array}$ & $\begin{array}{l}2.220 \\
2.127\end{array}$ & 1.512 & 1.118 \\
\hline 3 & Barbados & & & -0.413 & -0.102 & 0.634 & & & 0.935 & 1.181 & 1.040 & \\
\hline 4 & Belgium & * & -0.788 & 0.631 & 2.028 & -0.273 & -0.559 & 3.332 & 1.990 & 1.875 & 1.676 & 1.023 \\
\hline 5 & Botswana & * & & -0.483 & 0.144 & -0.574 & & & 10.328 & 4.763 & 4.009 & \\
\hline 6 & Bulgaria & & & & -0.217 & -0.471 & -1.263 & & & -0.154 & 4.346 & 1.841 \\
\hline 7 & Burkina Faso & * & 0.770 & 0.147 & 1.344 & -0.935 & 0.563 & 3.251 & 3.460 & 5.176 & 6.050 & 4.844 \\
\hline 8 & Burundi & & & -0.645 & -0.111 & 0.874 & 0.786 & & 4.361 & -1.989 & 3.274 & 2.087 \\
\hline 9 & Cameroon & & -0.562 & 0.545 & -1.051 & -0.137 & 0.347 & 6.311 & 3.272 & 1.361 & 3.255 & 4.959 \\
\hline 10 & Canada & * & -0.435 & 1.280 & 0.943 & 1.945 & & 3.972 & 2.608 & 2.807 & 2.291 & \\
\hline 11 & Chad & & & & -0.759 & -0.548 & 0.227 & & & 2.252 & 10.160 & 4.519 \\
\hline 12 & Chile & $*$ & & 0.148 & 0.382 & -0.364 & -0.248 & & 2.878 & 6.070 & 4.135 & 3.462 \\
\hline 13 & China, People's Rep. of & & & & -1.048 & 1.509 & -0.044 & & & 9.920 & 10.032 & 7.391 \\
\hline 14 & Colombia & & & & -0.073 & 0.818 & -0.228 & & & 2.625 & 3.995 & 4.059 \\
\hline 15 & Costa Rica & * & 0.093 & 0.481 & -0.780 & -0.070 & 0.067 & 5.487 & 2.482 & 4.752 & 4.212 & 3.932 \\
\hline 16 & Cyprus & & & 2.347 & 0.354 & 2.170 & -0.299 & & 6.047 & 4.217 & 2.927 & -1.018 \\
\hline 17 & Czech Republic & & & & 0.277 & -0.724 & 0.215 & & & 2.534 & 3.126 & 1.701 \\
\hline 18 & Denmark & * & 0.902 & 0.861 & 2.628 & -0.371 & -0.174 & 2.135 & 2.066 & 2.636 & 0.767 & 1.170 \\
\hline 19 & Dominica & & & & -0.674 & -0.249 & 0.044 & & & 1.768 & 2.461 & 0.445 \\
\hline 20 & Dominican Republic & * & 1.953 & -0.023 & & -1.300 & 0.141 & 6.882 & 2.343 & & 4.791 & 5.169 \\
\hline 21 & Fiji & & 0.190 & 0.577 & -0.763 & 0.211 & -0.202 & 4.816 & 1.365 & 2.321 & 1.551 & 3.850 \\
\hline 22 & Finland & * & -0.384 & 1.128 & 0.336 & -0.541 & 0.525 & 3.709 & 3.094 & 1.589 & 1.589 & 0.226 \\
\hline 23 & France & $*$ & 2.255 & -0.501 & -0.335 & -0.043 & 0.196 & 3.558 & 2.455 & 1.440 & 1.123 & 1.000 \\
\hline 24 & Gambia, The & $*$ & 0.009 & -1.175 & 0.511 & & & 4.776 & 3.553 & 3.236 & & \\
\hline 25 & Germany & & & & 2.246 & -1.016 & 0.243 & & & 1.836 & 0.810 & 1.619 \\
\hline 26 & Greece & * & 1.974 & -0.606 & 0.642 & -1.964 & 0.024 & 4.495 & 0.684 & 2.250 & 1.485 & -3.385 \\
\hline 27 & Grenada & & & 0.446 & 0.605 & 0.221 & -0.017 & & 4.466 & 3.412 & 1.765 & 2.817 \\
\hline 28 & Honduras & $*$ & -0.484 & -1.167 & 1.139 & & & 5.259 & 2.394 & 3.233 & & \\
\hline 29 & Hong Kong, China & & & & -0.307 & 1.930 & -0.323 & & & 3.876 & 3.991 & 2.760 \\
\hline
\end{tabular}




\begin{tabular}{|c|c|c|c|c|c|c|c|c|c|c|c|c|}
\hline & & & & & redit Skewnes & & & & Mean & DP per Capita & Growth & \\
\hline & Economy & & $1971-1980$ & 1981-1990 & 1991-2000 & 2001-2010 & $2011-2016$ & 1971-1980 & 1981-1990 & 1991-2000 & 2001-2010 & $2011-2016$ \\
\hline 30 & Iceland & * & & -0.339 & 1.225 & 0.363 & 0.187 & & 3.271 & 2.564 & 2.527 & 3.395 \\
\hline 31 & India & * & 0.543 & -0.015 & 0.542 & -0.407 & 1.068 & 2.960 & 5.407 & 5.427 & 7.245 & 6.575 \\
\hline 32 & Indonesia & * & & 0.807 & -1.756 & 0.188 & 0.477 & & 5.345 & 3.808 & 5.100 & 5.298 \\
\hline 33 & Israel & * & & -0.052 & -0.108 & 0.185 & 0.046 & & 3.566 & 5.777 & 3.187 & 3.521 \\
\hline 34 & Italy & * & 0.192 & -0.153 & 0.082 & -0.352 & -0.364 & 3.731 & 2.372 & 1.397 & 0.149 & -0.376 \\
\hline 35 & Jamaica & * & & -0.398 & -0.072 & -1.424 & 0.416 & & 2.636 & 1.765 & 0.667 & 0.774 \\
\hline 36 & Japan & * & 0.580 & 0.886 & 0.384 & -2.392 & -0.010 & 4.366 & 4.531 & 1.330 & 0.636 & 0.982 \\
\hline 37 & Jordan & * & & -0.507 & 0.183 & 0.939 & -0.113 & & 1.967 & 5.010 & 6.113 & 2.559 \\
\hline 39 & Kazakhstan & & & & 0.201 & -0.140 & -0.217 & & & -1.392 & 7.951 & 3.993 \\
\hline 39 & Kenya & * & -0.500 & 0.482 & -0.340 & 1.316 & -0.097 & 7.702 & 3.986 & 1.854 & 4.231 & 5.427 \\
\hline 40 & Korea, Rep. of & * & -0.307 & -0.412 & -0.122 & -0.007 & -0.198 & 8.798 & 9.450 & 6.712 & 4.327 & 2.927 \\
\hline 41 & Luxembourg & & 1.447 & -0.144 & & 0.014 & -0.600 & 2.555 & 4.832 & & 2.679 & 3.260 \\
\hline 42 & Macau, China & & & & 0.875 & 0.361 & -0.123 & & & 2.637 & 10.707 & 1.907 \\
\hline 43 & Macedonia, FYR & & & & -0.570 & -0.069 & 0.071 & & & 1.676 & 2.930 & 2.409 \\
\hline 44 & Madagascar & * & 0.786 & 0.306 & -0.243 & & & 0.988 & 0.525 & 1.718 & & \\
\hline 45 & Malawi & * & & 0.905 & 0.172 & 0.979 & 0.383 & & 2.178 & 3.384 & 4.640 & 3.742 \\
\hline 46 & Malaysia & * & 0.216 & -1.204 & 0.994 & -1.020 & 0.096 & 7.539 & 5.806 & 6.865 & 4.505 & 4.986 \\
\hline 47 & Mali & & & & -0.689 & 1.184 & 0.236 & & & 3.990 & 5.647 & 3.739 \\
\hline 48 & Malta & & 0.696 & 1.034 & 0.654 & & & 9.417 & 3.827 & 5.014 & & \\
\hline 49 & Mauritius & & & 0.826 & -0.606 & 1.371 & -0.294 & & 5.846 & 5.194 & 4.160 & 3.576 \\
\hline 50 & Mexico & * & -1.808 & 0.442 & -0.149 & -0.265 & -0.838 & 6.469 & 1.791 & 3.520 & 1.767 & 2.728 \\
\hline 51 & Mongolia & & & & 0.517 & 0.271 & 0.565 & & & 0.982 & 6.279 & 8.246 \\
\hline 52 & Morocco & & & & 1.977 & 0.965 & 1.395 & & & 2.866 & 4.828 & 3.423 \\
\hline 53 & Myanmar & & -0.291 & 1.510 & -0.114 & -0.575 & 0.266 & 4.546 & 1.274 & 6.907 & 11.312 & 6.939 \\
\hline 54 & Nepal & & & -0.372 & 0.773 & -0.385 & 0.962 & & 4.623 & 4.870 & 3.840 & 3.524 \\
\hline 55 & Netherlands & * & 0.325 & 1.596 & 0.250 & 0.058 & 0.724 & 2.922 & 2.205 & 2.722 & 1.207 & 0.976 \\
\hline 56 & New Zealand & * & & 2.550 & -0.328 & -0.418 & & & 1.874 & 3.040 & 2.523 & \\
\hline 57 & Niger & * & 0.563 & 0.481 & 0.048 & 0.490 & 0.210 & 1.255 & -0.109 & 1.768 & 4.470 & 5.637 \\
\hline 58 & Norway & * & -0.477 & 0.515 & -0.308 & -0.476 & -0.023 & 4.610 & 2.539 & 3.615 & 1.548 & 1.540 \\
\hline 59 & Pakistan & & -0.535 & 0.091 & 0.285 & & & 4.576 & 6.093 & 3.864 & & \\
\hline 60 & Panama & * & & -1.039 & -0.500 & -1.605 & 0.401 & & 1.357 & 5.061 & 5.616 & 7.111 \\
\hline
\end{tabular}




\begin{tabular}{|c|c|c|c|c|c|c|c|c|c|c|c|c|}
\hline & \multirow[b]{2}{*}{ Economy } & & \multicolumn{5}{|c|}{ Credit Skewness } & \multicolumn{5}{|c|}{ Mean GDP per Capita Growth } \\
\hline & & & $1971-1980$ & 1981-1990 & $1991-2000$ & $2001-2010$ & $2011-2016$ & $1971-1980$ & 1981-1990 & $1991-2000$ & $2001-2010$ & $2011-2016$ \\
\hline 61 & Papua New Guinea & $*$ & 0.973 & -0.957 & 1.219 & & & 0.967 & 1.251 & 4.015 & & \\
\hline 62 & Paraguay & $*$ & 0.167 & 1.477 & 0.358 & -0.325 & -1.043 & 8.532 & 4.013 & 2.378 & 3.386 & 4.614 \\
\hline 63 & Poland & & & & -0.405 & 0.935 & -0.507 & & & 3.641 & 3.849 & 2.919 \\
\hline 64 & Portugal & $*$ & -1.217 & -0.304 & -0.310 & -0.251 & -0.614 & 4.631 & 3.200 & 2.612 & 0.605 & -0.539 \\
\hline 65 & Rwanda & & -0.078 & -0.404 & -0.366 & & & 5.244 & 2.011 & 0.073 & & \\
\hline 66 & Senegal & $*$ & 1.106 & 0.575 & -1.263 & 0.905 & 1.073 & 1.687 & 2.554 & 3.036 & 4.013 & 4.405 \\
\hline 67 & Seychelles & & -0.072 & 0.789 & -0.134 & -0.510 & 1.009 & 6.379 & 3.031 & 4.155 & 1.998 & 5.162 \\
\hline 68 & Solomon Islands & & & & -0.367 & 0.303 & -0.466 & & & 2.441 & 2.766 & 4.969 \\
\hline 69 & Spain & $*$ & 0.216 & 0.186 & 0.471 & -0.142 & 0.149 & 2.904 & 2.892 & 2.245 & 2.003 & 0.335 \\
\hline 70 & St. Lucia & & & 1.226 & 0.858 & 0.758 & -0.377 & & 7.612 & 2.230 & 1.752 & 0.302 \\
\hline 71 & Suriname & & & -0.014 & 0.911 & 1.914 & -0.960 & & -1.124 & 0.675 & 4.864 & -0.348 \\
\hline 72 & Swaziland & & 0.213 & 0.137 & & -0.565 & 0.034 & 6.038 & 8.851 & & 3.478 & 2.808 \\
\hline 73 & Sweden & $*$ & -0.665 & 0.685 & -0.752 & 2.640 & -0.019 & 1.940 & 2.171 & 2.111 & 2.083 & 2.213 \\
\hline 74 & Switzerland & $*$ & & 1.364 & 0.355 & 0.046 & 0.873 & & 2.197 & 1.194 & 1.843 & 1.449 \\
\hline 75 & Thailand & $*$ & 0.381 & -0.185 & -0.567 & -0.566 & 0.310 & 6.632 & 7.557 & 4.301 & 4.490 & 2.919 \\
\hline 76 & Tonga & & & & 1.091 & 1.138 & 0.042 & & & 2.830 & 1.397 & 1.598 \\
\hline 77 & Tunisia & & & & 1.381 & 0.932 & 1.097 & & & 4.632 & 4.132 & 1.651 \\
\hline 78 & Turkey & $*$ & -0.117 & 0.839 & -0.058 & -0.948 & 0.670 & 3.985 & 5.103 & 3.549 & 3.932 & 6.187 \\
\hline 79 & Ukraine & & & & 1.292 & -0.960 & -0.453 & & & -8.047 & 4.196 & -1.541 \\
\hline 80 & United Kingdom & & & & 0.163 & -1.044 & 0.734 & & & 2.364 & 1.573 & 1.947 \\
\hline 81 & United States & * & -0.150 & -0.189 & -1.019 & -2.135 & -0.495 & 3.119 & 3.281 & 3.383 & 1.630 & 1.993 \\
\hline 82 & Uruguay & $*$ & 2.151 & 0.767 & 2.078 & -0.611 & -1.055 & 2.970 & -0.026 & 3.345 & 2.987 & 3.007 \\
\hline
\end{tabular}

FYR = Former Yugoslav Republic, GDP = gross domestic product.

Note: * Refers to economies from the Ranciere, Tornell, and Westermann (2008) sample.

Source: Authors' estimates. 


\section{REFERENCES}

Adrian, Tobias, Nina Boyarchenko, and Domenico Giannone. 2017. "Vulnerable Growth.” Federal Reserve Bank of New York Staff Report No. 794.

Aghion, Philippe, George-Marios Angeletos, Abhijit Banerjee, and Kalina Manova. 2005. "Volatility and Growth: Credit Constraints and Productivity-Enhancing Investment." NBER Working Paper No. 11349.

Arcand, Jean-Louis, Enrico Berkes, and Ugo Panizza. 2012. "Too Much Finance?" International Monetary Fund Working Paper 12/161.

Beck, Thorsten, and Ross Levine. 2004. "Stock Markets, Banks and Growth: Panel Evidence." Journal of Banking and Finance 28 (3): 423-42.

Bekaert, Geert, and Alexander Popov. 2012. "On the Link between Volatility and Skewness of Growth.” NBER Working Paper No. 18556.

Bezemer, Dirk J. 2012. "Finance and Growth: When Credit Helps, and When it Hinders." Paper presented at the "Paradigm Lost" INET conference in Berlin, April 12-15.

Bezemer, Dirk, Maria Grydaki, and Zhang Lu. 2014. "Is Financial Development Bad for Growth?" University of Groningen Research Report No. 14016-GEM.

Bulmer, Michael George. 1979. Principles of Statistics. New York: Dover Publications.

Caballero, Ricardo, Takeo Hoshi, and Anil Kashyap. 2008. "Zombie Lending and Depressed Restructuring in Japan." American Economic Review (98) 5: 1943-77.

Demirgüç-Kunt, Asli, and Ross Levine. 1996. "Stock Markets, Corporate Finance, and Economic Growth.” World Bank Economic Review 10 (2): 223-39.

—. 2008. "Finance, Financial Sector Policies, and Long-Run Growth." World Bank Policy Research Working Paper No. 4469.

Easterly, William, Roumeen Islam, and Joseph Stiglitz. 2000. "Shaken and Stirred: Explaining Growth Volatility." Paper presented at the 2000 Annual World Bank Conference on Development Economics, April 18-20, Washington, DC.

Estrada, Gemma, Donghyun Park, and Arief Ramayandi. 2010. "Financial Development and Economic Growth in Developing Asia.” ADB Economics Working Papers Series No. 23.

King, Robert G., and Ross Levine. 1993. "Finance, Entrepreneurship, and Growth: Theory and Evidence." Journal of Monetary Economics 32 (3): 513-42.

Laeven, Luc, and Fabian Valencia. 2012. "Systemic Banking Crises Database: An Update." International Monetary Fund Working Paper 12/163.

Levine, Ross 2004. "Finance and Growth: Theory and Evidence.” NBER Working Paper No. 10766. 
Levine, Ross, and Sara Zervos. 1998. "Stock Markets, Banks, and Economic Growth." American Economic Review 88 (3): 537-58.

Philippon, Thomas. 2012. "Has the US Finance Industry Become Less Efficient? On the Theory and Measurement of Financial Intermediation.” NBER Working Paper No. 18077.

Popov, Alexander. 2014. "Credit Constraints, Equity Market Liberalization, and Growth Rate Asymmetry." Journal of Development Economics 107: 202-14.

Ramey, Garey, and Valerie Ramey. 1995. "Cross-Country Evidence on the Link Between Volatility and Growth.” American Economic Review 85 (5): 1138-51.

Ranciere, Romain, Aaron Tornell, and Frank Westermann. 2006. "Decomposing the Effects of Financial Liberalization: Crises vs. Growth.” Journal of Banking and Finance 30 (12): 3331-48.

_. 2008. "Systemic Crises and Growth.” Quarterly Journal of Economics 123 (1): 359-406.

Reinhart, Carmen M., and Kenneth S. Rogoff. 2011. "From Financial Crash to Debt Crisis." American Economic Review 101 (5): 1676-706.

Salgado, Sergio, Faith Guvenen, and Nicholas Bloom. 2015. "Skewed Business Cycles." https://people.stanford.edu/nbloom/sites/default/files/sgb_firm_skew_2016_ss_v1_edited.pdf. 


\section{Skewed Credit and Growth Dynamics after the Global Financial Crisis}

This working paper explores the association between economic growth and systemic financial risk. It uses elements of private credit growth to measure system financial risk. Using cross-country panel data, it finds that the beneficial effects of systemic risk on economic growth were evident only prior to 2000. The findings help explain why boom-bust dynamics were positively associated with economic growth in emerging markets in the past and why the growth of advanced economies has been sluggish since the global financial crisis.

\section{About the Asian Development Bank}

ADB is committed to achieving a prosperous, inclusive, resilient, and sustainable Asia and the Pacific, while sustaining its efforts to eradicate extreme poverty. Established in 1966, it is owned by 67 members48 from the region. Its main instruments for helping its developing member countries are policy dialogue, loans, equity investments, guarantees, grants, and technical assistance.

$\mathrm{ADB}$ 